\title{
The Holocaust in the Romanian Borderlands
}

This volume examines the changing role which ordinary members of society played in the state-sponsored persecution of the Jews in Bukovina and Bessarabia, both during the summer of 1941, when Romania joined the Nazi invasion of the Soviet Union, and beyond. It establishes different patterns of civilian complicity and discusses the significance of the phenomenon in the context of the exterminatory campaign pursued by the Romanian military authorities against the Jews living in the borderlands.

Mihai I. Poliec holds a PhD in History from Clark University, USA. 
Mass Violence in Modern History

Edited by Alexander Korb and Uğur Ümit Üngor

1 Knowledge and Acknowledgement in the Politics of Memory of the Armenian Genocide

Vahagn Avedian

2 Local Dimensions of the Second World War in Southeastern Europe

Edited by Xavier Bougarel, Hannes Grandits and Marija Vulsica

3 The White Terror

Antisemitic and Political Violence in Hungary, 1919-1921

Béla Bodó

4 The Holocaust in the Romanian Borderlands

The Arc of Civilian Complicity

Mihail I. Poliec 


\title{
The Holocaust in the Romanian Borderlands \\ The Arc of Civilian Complicity
}

\author{
Mihai I. Poliec
}


First published 2019

by Routledge

2 Park Square, Milton Park, Abingdon, Oxon OX14 4RN

and by Routledge

52 Vanderbilt Avenue, New York, NY 10017

Routledge is an imprint of the Taylor \& Francis Group, an informa business

(C) 2019 Mihai I. Poliec

The right of Mihai I. Poliec to be identified as author of this work has been asserted by him in accordance with sections 77 and 78 of the Copyright, Designs and Patents Act 1988.

All rights reserved. No part of this book may be reprinted or reproduced or utilised in any form or by any electronic, mechanical, or other means, now known or hereafter invented, including photocopying and recording, or in any information storage or retrieval system, without permission in writing from the publishers.

Trademark notice: Product or corporate names may be trademarks or registered trademarks, and are used only for identification and explanation without intent to infringe.

British Library Cataloguing in Publication Data

A catalogue record for this book is available from the British Library

Library of Congress Cataloging in Publication Data

Names: Poliec, Mihai I., author.

Title: The Holocaust in the Romanian borderlands: the arc in the Romanian borderlands/Mihai I. Poliec.

Description: Milton Park, Abingdon, Oxon: New York, NY: Routledge, [2019] | "This volume examines the changing role which ordinary members of society played in the state-sponsored persecution of the Jews in Bukovina and Bessarabia, both during the summer of 1941, when Romania joined the Nazi invasion of the Soviet Union, and beyond. It establishes different patterns of civilian complicity and discusses the significance of the phenomenon in the context of the exterminatory campaign pursued by the Romanian military authorities against the Jews living in the borderlands"-Provided by publisher. Includes index. | Includes bibliographical references.

Identifiers: LCCN 2019006990 | ISBN 9780367218188 (hardback)|

ISBN 9780429266294 (ebook) | ISBN 9780429561269 (epub)

Subjects: LCSH: Holocaust, Jewish (1939-1945)-Bukovina (Romania and Ukraine)-Citizen Participation. | Holocaust, Jewish (1939-1945)-Bessarabia (Moldova and Ukraine)-Citizen Participation. | Romania-History-1914-1944. Jews-Perscecutions-Bukovina (Romania and Ukraine) $\mid$ Jews-PerscecutionsBessarabia (Moldova and Ukraine) | Bukovina (Romania and Ukraine)-Ethnic relations. | Bessarabia (Moldova and Ukraine)-Ethnic relations.

Classification: LCC DS135.R72 B845 2019 | DDC 940.53/1809476-dc23

LC record available at https://lccn.loc.gov/2019006990

ISBN: 978-0-367-21818-8 (hbk)

ISBN: 978-0-429-26629-4 (ebk)

Typeset in Times New Roman

by Deanta Global Publishing Services, Chennai, India 
In honor of Corina and Mihai Poliec and in memory of the Romanian Jews betrayed by neighbors and country during the Holocaust.

"The end preexists in the means."

Ralph Waldo Emerson 


\section{Contents}

List of illustrations viii

Acknowledgments $\quad$ ix

Introduction $\quad 3$

1 The beginning of the end: mass killing and physical violence 48

2 Civilian complicity during camp internment, ghettoization and deportation 84

3 Pressure from below: petitioning, collective complaint and denunciation 114

$\begin{array}{lr}\text { Conclusion } & 159\end{array}$

$\begin{array}{ll}\text { Index } & 171\end{array}$ 


\section{Illustrations}

\section{Maps}

1 Romania - 1933

2 Romania- 1942

3 Romanian participation in Massacres 1941-1942

4 Romanian deportations to Transnistria 1941-1942

\section{Figure}

1.1 Vladimir Rusu 


\section{Acknowledgments}

Behind this book there is a long journey which was shaped by institutions and people with whom I have come into contact during my academic and personal life. I wish to thank Clark University and the Strassler Center for Holocaust and Genocide Studies. The advancement in my research and the successful completion of the doctoral project were achieved almost entirely with the financial support of The Conference on Jewish Material Claims Against Germany (Claims Conference), to which I am most grateful. During my archival research I have benefited from the assistance of the staff at the Library and Archives of the United States Holocaust Memorial Museum and I wish to thank them for that. Many thanks to my doctoral dissertation committee: Thomas Kühne, Vladimir Solonari and Radu Ioanid.

My academic growth was first nurtured on the Old Continent and for that I wish to acknowledge the formative contributions of the Goldstein-Goren Center for Hebrew Studies at the University of Bucharest, the Rothberg School for International Students at the Hebrew University of Jerusalem, and Paideia - The European Institute for Jewish Studies in Sweden.

I wish to also thank all my professors as well as the researchers and scholars with whom I crossed paths and engaged in inspiring conversations. I am grateful to Paul Shapiro for his important suggestions during my research. I want to acknowledge the receptivity and assistance of the Consiliul Naţional pentru Studierea Arhivelor Securității (CNSAS) in Bucharest, and to thank Adrian Cioflâncă. Special praise goes to all those living in and outside Romania who are perennially committed to promoting historical responsibility for the Holocaust in that country.

I would like to express special thanks to Routledge and its editorial staff for improving the manuscript which was entrusted to them and for ensuring the materialization of the project. The same appreciation goes to the anonymous reviewers for their insightful comments.

During my postgraduate studies I was able to rely on a support network whose solidarity alleviated some of the burden. To all my family and friends, it was a privilege to have you by my side, especially when sailing in the stormiest of waters!

Lastly, I direct my profound gratitude to the Holocaust survivors whom I have encountered in my lifetime. You gave me a sense of the excruciating helplessness which extreme victimization imposes upon the victimized. 


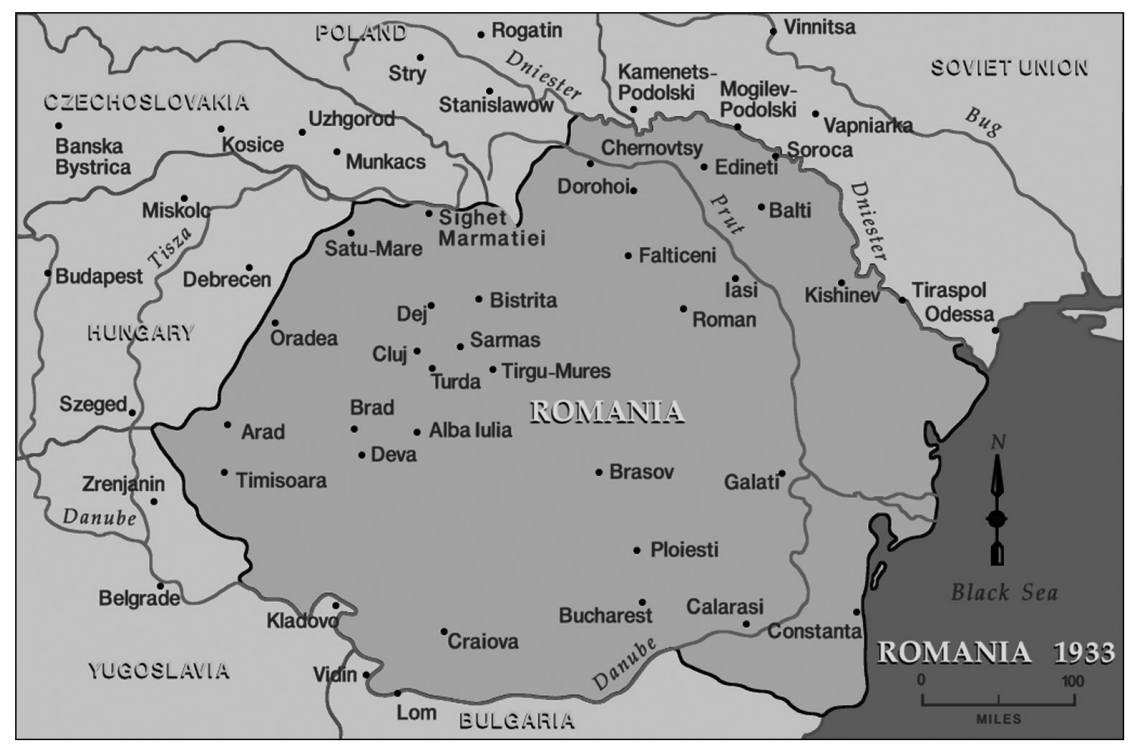

Map 1 Romania-1933.

Source: U.S. Holocaust Memorial Museum.

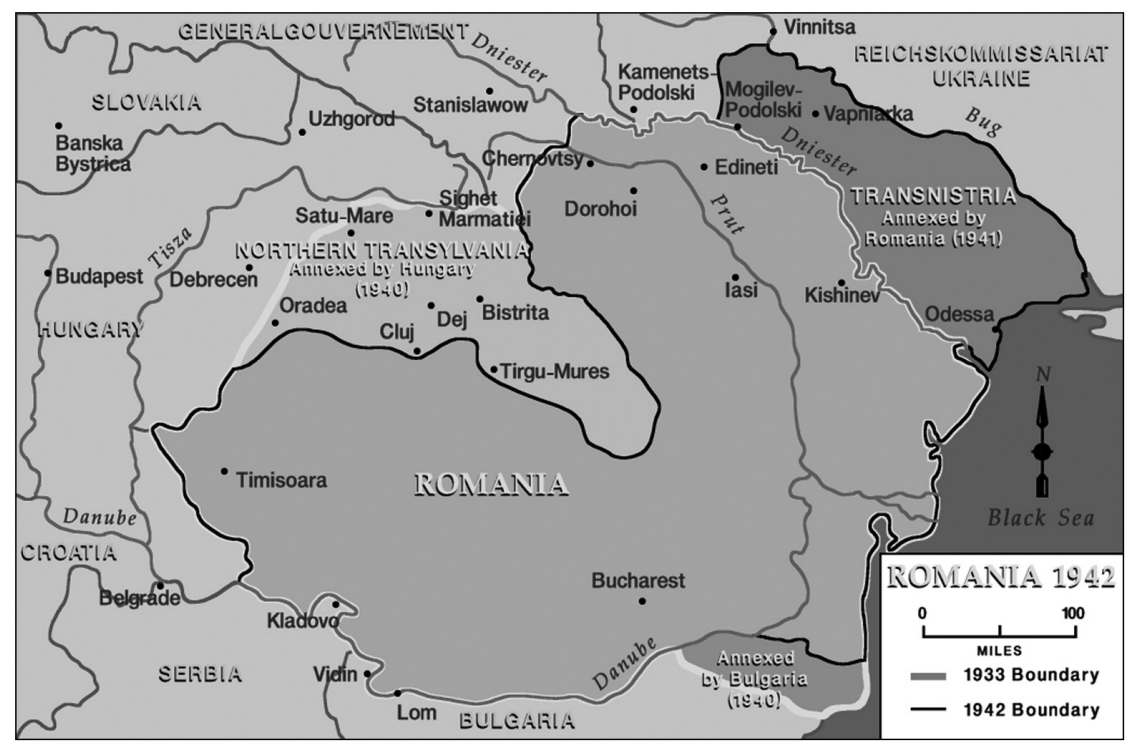

Map 2 Romania-1942.

Source: U.S. Holocaust Memorial Museum. 


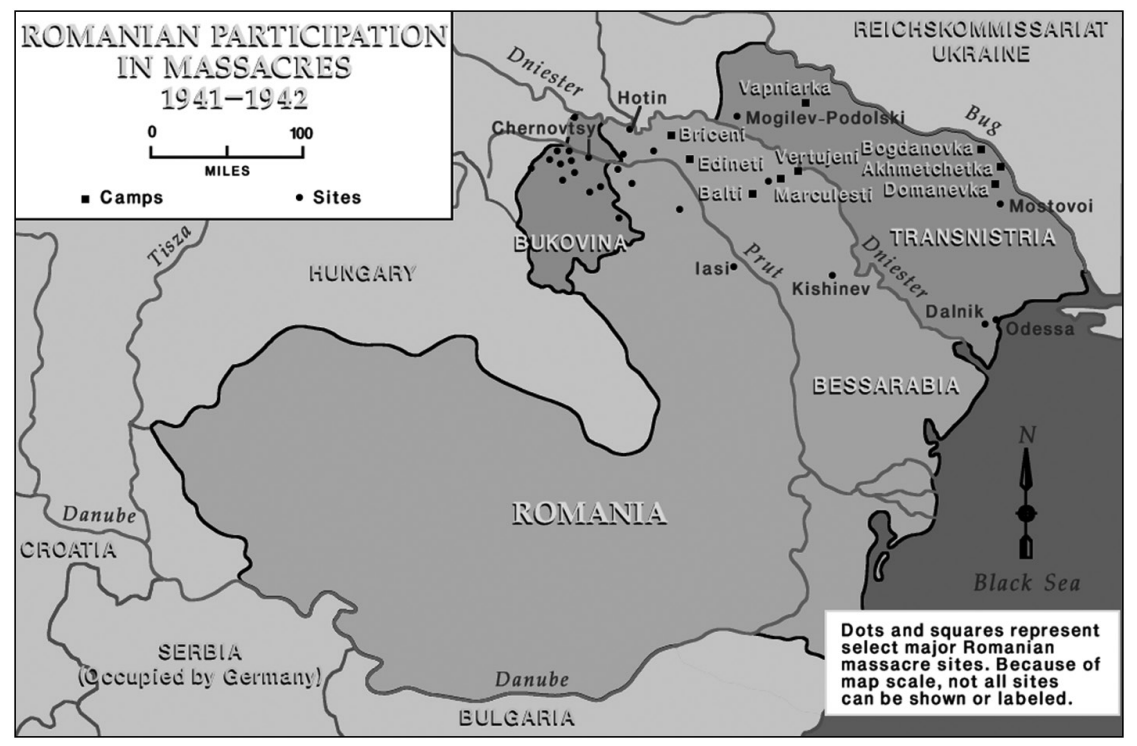

Map 3 Romanian participation in massacres 1941-1942.

Source: U.S. Holocaust Memorial Museum.

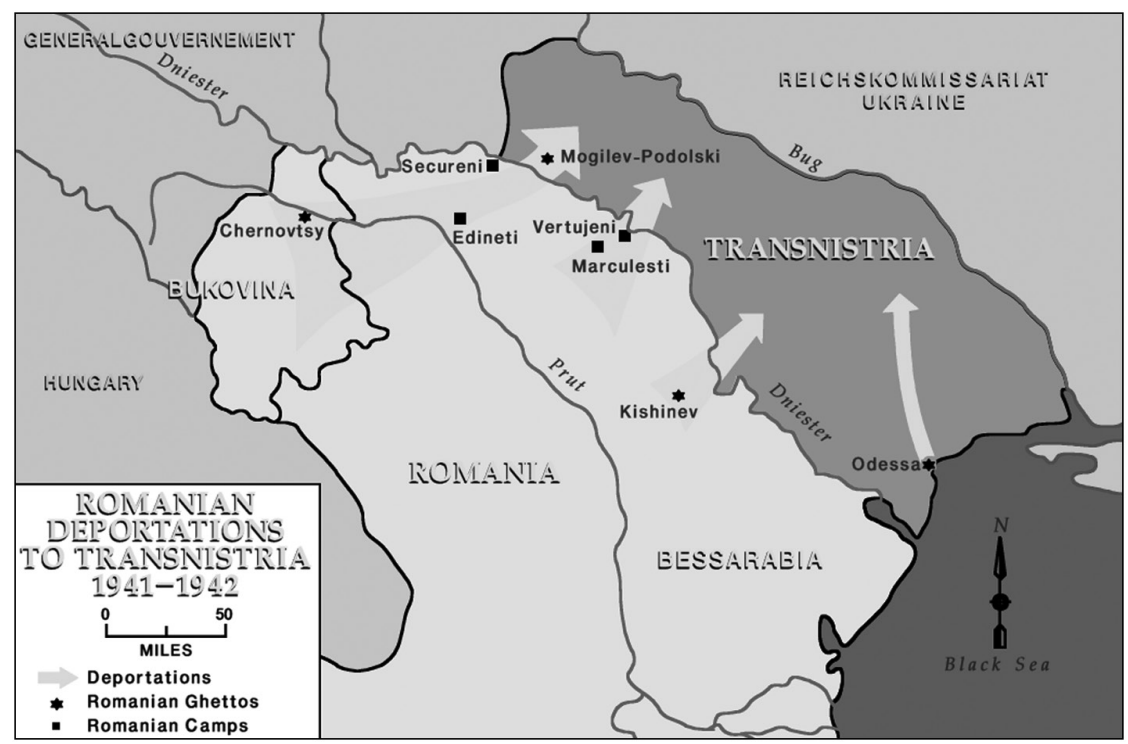

Map 4 Romanian deportations to Transnistria 1941-1942.

Source: U.S. Holocaust Memorial Museum. 


\section{Introduction}

Reflecting on how narratives of past events are formed, the French writer Paul Valéry wrote that "History is the most dangerous product the chemistry of the intellect has ever concocted... It sets people dreaming, it intoxicates them, spawns in them false memories, exaggerates their reflexes, keeps old wounds open, torments them in their repose, prompts them to delusions of grandeur or deliriums of persecution, and makes nations bitter, arrogant, unbearable and vain."1 That a product of the human intellect can become autonomous and potent to such a degree that it ends up possessing and transforming its source should not surprise anyone considering the robust record of horrific atrocities perpetrated as a result of arbitrary interpretations of the past. Not only do groups construct and entertain a nuanced memory of their past, but they also generate strict and exclusive categories of self-understanding. Benedict Anderson's timeless observation that nation-ness and its derivatives nationality and nationalism are in essence cultural artifacts, which nowadays command profound emotional legitimacy is a powerful reminder in this sense. ${ }^{2}$

While an abstract community at the narrative level, the nation acquires concrete shape through the collective pursuit of a political consciousness and of political rights within a defined territory. Internalizing the immediate realities which separate the group and its pursuit from the ultimate achievement of self-determination contributes to the formation of that group's psychological make-up. Romania's assiduous endeavors during the late eighteenth and early nineteenth centuries to overcome its geographical vulnerability, become independent from its dominant neighbors and obtain the recognition of its sovereignty from the European powers, propelled the country into achieving its trans-generational imperative but also predisposed it to an obtuse approach to alterity. The Romanian nationalists' doctrine incorporated a specifically anti-Jewish xenophobia. When disseminated and preached to the Romanian masses, the militant dimension of the anti-Jewish theme often led to violence. ${ }^{3}$

This book brings to the forefront through a scrupulous reconstruction the participation of civilians in the organized top-down eradication of Jewish life and massive plunder of Jewish property in Bukovina and Bessarabia during World War II. The actions examined are not interpreted as a manifestation of evil or psychopathology but as an expression of the destructiveness of which ordinary members of 
society are capable. Because it was human action that made possible the systematic eradication of most of Europe's Jewish population, it is the human story of the local perpetrators that is at the core of this study. In a personalized thank-you note dated June 17, 1942, the Government of Bessarabia "warmly thanked" Maria Vasiliu for "how you contributed to the fight against the Jewish element, by participating in the capture of the Jews Clara and Marcel Schwartzberg." Besides her being an ethnic Romanian and a resident of Chișinău, both Vasiliu's background and the circumstances of her involvement remain unknown. My research aimed to shed light on these often-obscure cases.

The Holocaust in the Romanian Borderlands examines the magnitude and significance of Christian civilians' involvement in the Romanian military regime's persecution of the Jews in Bessarabia and Bukovina, after Romania joined the Nazi invasion of the Soviet Union in the summer of 1941. Bessarabia and Bukovina are two regions that belonged earlier in their history to the Principality of Moldavia. Following the Russo-Turkish War of 1806-1812, the eastern portion of Moldavia was ceded to Imperial Russia and was designated "Bessarabia." Meanwhile, the northern part of the Principality of Moldavia was annexed by the Habsburg Monarchy in 1775 and given the name "Bukovina." In 1918, after World War I, both Bukovina and Bessarabia were incorporated into Greater Romania. In the summer of 1940 Romania was forced to cede Bessarabia and northern Bukovina to the Soviet Union. Historically and at the time when they were ceded, both regions had a dense network of Jewish communities. Under the military dictatorship of Ion Antonescu (September 1940 - August 1944), the Jewish population in Bessarabia and Bukovina was subject to systematic violence and deportation to a region in Ukraine known as Transnistria.

The persecution of the Jews in Eastern Europe was informed by geography. Jews fell victim primarily in disputed territories. In the case of Hungary, it was the Jews in occupied Yugoslavian territory and Ukraine who were targeted first. In Bulgaria, the Jews from Macedonia and Thrace were the ones who were sent to the extermination camps. Similarly, in Romania it was the Jewish population residing in territories lost to and then re-annexed from the Soviet Union that were victimized most. ${ }^{5}$ By the time Romania entered the war, the country's Jews had already endured systematic social exclusion as a result of antisemitic legislation and had suffered from popular violence. In Bukovina and Bessarabia after July 1941, the Jews suffered more than their brethren in other parts of the country. In the two recovered regions, Jews were subject to identification, ghettoization, deportation and extermination through mass shooting, disease or starvation. ${ }^{6}$ Ion Antonescu had a more hostile attitude toward the Bessarabian and Bukovinian Jews due to the latter's alleged attacks on the withdrawing Romanian army in June 1940. The two borderland regions were regarded as an absolute priority to the government's demographic policy. Due to the uncertain future of the two regions and also the Soviet threat, the Romanian administration was resolute in ethnically purifying the region of its minorities, in particular the Slavic ones. ${ }^{7}$

The historiography on the role of civilians in the Holocaust in Bessarabia and Bukovina needs further research to document and help explain how and why 
various ordinary members of society became active participants in the persecution of the Bukovinian and Bessarabian Jews. The local perpetrators in the borderland regions have yet to become the center of scholarly attention and a subject deemed worthy of a monograph. ${ }^{8}$

The Holocaust in the Romanian Borderlands seeks to establish different patterns of civilian complicity and to discuss their significance in the context of the crimes committed against the Jews by the Romanian military authorities during and beyond July 1941. I will look at the roles civilians played in the implementation of anti-Jewish policies by the military authorities and try to identify both the objective factors and subjective determinants that prompted the former to become complicit.

\section{Historical background}

Before Romania became Germany's major ally on the eastern front after 1941, it was one of Eastern Europe's cradles of Jewish life. Up until the nineteenth century, no major antisemitic outbursts were recorded in the history of the Romanian Principalities, despite the xenophobia triggered by the extensive Turkish rule. ${ }^{9}$ However, religious antisemitism was able to permeate the social fabric of the Romanian-speaking space very early in its history due to the influential role that the Church enjoyed. During the Quinisext Council held in 692 at Constantinople, the more than 200 bishops who gathered from all over the Eastern Roman Empire established punitive measures for Christians who sought medical assistance from Jewish physicians. From the fourteenth century on, deicide charges would become a commonplace in the catechisms produced by the Orthodox Church. A Wallachian code of 1652 promised excommunication to Romanians who failed to observe strict segregation in relation to the Jews and warned of divine retribution against those worshippers who engaged in sexual intercourse with them. ${ }^{10}$

The Romanian Orthodox Church was responsible for the perpetuation of popular antisemitic perceptions well into the nineteenth century. Moses Schwartzfeld, a Romanian Jewish intellectual who authored one of the earliest psycho-ethnologic studies on the representation of the Jews in Romanian folk literature, concluded that the portrayal of Jews in superstitions, anecdotes, proverbs and songs inspired by the Church concentrated on them being a doomed people as well as a murderous and predatory community mandated by Satan. ${ }^{11}$ The profile of the imaginary Jew could develop autonomously and incorporate the characteristics of a supernatural being without the "real Jew" having any possibility to counteract it. The greater the gap between the real and the imaginary Jew, the more intense was the Judeophobia. ${ }^{12}$ If antisemitic folklore is autobiographical ethnography, then the traits ascribed to the Jew in it are indicative not of who the historical Jew was but of the Christian mindset responsible for the respective projections. ${ }^{13}$

Romanian antisemitism was surviving as more than just a conceptual reality. A foreign observer's report in 1900 was indicative of its scope. The French ambassador to Bucharest, A. Henry, wrote: "Antisemitism is more than just an idea. It is a passion common to politicians of all parties, the Orthodox church, and, one 


\section{Introduction}

could also add, to all peasants, both Wallachian and Moldavian." ${ }^{14}$ It is of little surprise that Henry was able to assess the magnitude of antisemitism during his stay in Romania. With the penetration of capitalism during the nineteenth century, Romanian antisemitism became a noticeable social phenomenon. ${ }^{15}$ Unlike the long-established Sephardic Jews of Wallachia, who resided primarily in the cities on the Danube and attained a higher cultural level, the Galician, Ukrainian and Russian Jews who fled the tsarist empire's violent antisemitic policies and settled in Moldavia formed a middle class of merchants and artisans as well as doctors and lawyers, thus competing with the growing Romanian petty bourgeoisie. The reactions stirred up against this background, together with the pervasive influence of tsarist antisemitism, made Moldavia the epicenter of Romanian antisemitism. ${ }^{16}$

The Russian-inspired Organic Regulations of 1831 enforced upon the Jews living in the Romanian Principalities the condition of adherence to the Christian faith as a prerequisite for the attainment of civil and political rights. The political emancipation of the Jews in Wallachia and Moldavia remained a remote prospect throughout the eighteenth century. The political upheavals which swept through Europe in 1848 had no revolutionary consequences for the status of the Jews living in the two Romanian-speaking areas. Nor did the union of Wallachia and Moldavia in 1859. When the country's parliament adopted the first Constitution of Romania in 1866, Article 7 established that only foreigners of the Christian creed were eligible for Romanian citizenship. The enfranchisement of the Romanian Jews continued to be hindered until 1923, when Article 8 of the Constitution made emancipation a reality for the Jewish minority by granting them civil rights. Under pressure from Western powers, Romania agreed to safeguard its minorities.

As the borders shifted post-World War I, so did the demographic, cultural, religious and linguistic profile of the country's Jewish inhabitants. Following Bukovina's annexation at the end of World War I, along with Bessarabia and Transylvania, Romania's Jewish population nearly tripled. Jews arriving from Galicia, Ukraine and Soviet Russia, seeking refuge, further swelled the population. In Bukovina, Jews comprised 10.8 percent of the population, and in Bessarabia 7 percent. ${ }^{17}$ In terms of their historical experience and cultural specificity, the Bukovinian and Bessarabian Jews were different both from each other and from the Wallachian and Moldavian Jews. The Bukovinian Jewry had enjoyed complete equality under Habsburg rule and attained a certain degree of German acculturation. Outside the capital Cernăuți, the majority of Jews resided in small towns and spoke Yiddish. They embraced Orthodoxy and in some cases Hasidism. In the more backward region of Bessarabia, the sizable Jewish population had been subjected to a lengthy period of oppression by the tsarist regime. It was primarily Yiddish-speaking, Orthodox, and its members came from the lower-middle class and the proletariat. The latter had a numerically significant presence both in cities and small towns. As for the cultural orientation of the Bessarabian intelligentsia, it had a Russified character, unlike the Germanized outlook of its Bukovinian counterpart. ${ }^{18}$

Despite Jews constituting between 4 and 5 percent of Romania's interwar population, they were overrepresented in numerous occupations, a fact that 
antagonized Romanian antisemites and became an integral part of their argument against Jewish prepotency. ${ }^{19}$ Anti-Jewish hostility had been building up since the late 1800 s and early 1900 s when the dissemination by the press of the accusation that Jews were forcing Romanians out of the middle class, and that those residing in the countryside were responsible for poisoning the Romanian peasantry, fueled public gatherings primarily in the Moldavian city of Jassy and occasionally in Bucharest. Such gatherings often culminated in the vandalization of Jewish businesses. What their detractors failed to acknowledge was that the capital the Jews invested in the country's nascent industrial sector, as well as in the financial and commercial sectors, created employment and economic growth. ${ }^{20}$

In the postwar years, Romanian antisemitism gradually acquired a mass character due to the economic and political conditions in the country as well as its use as a means of diversion by fascist organizations and various bourgeois parties. Both categories endorsed antisemitic agitation, knowing that it would serve their objectives to blame the Romanian petty bourgeoisie's lack of social advancement on the competition created by the Jews. ${ }^{21}$ The Jews in Romania represented a perpetual irritation in the market and a reminder of internal economic challenges. For the intellectual, the Jew exemplified the alien and was responsible for the economic subjugation of the peasantry, who symbolized the soul of the Romanian nation. ${ }^{22}$ After 1918, the Romanian peasant represented more than a cherished symbol. He was at the core of the official elite formation endeavors. The schools in the Old Kingdom were experiencing an influx of recently emancipated peasants and collectively naturalized Jews. While the latter were treated as an illegitimate presence which threatened the school system's role in forging the new Romanian elite, the former were unequivocally welcomed as a fertile pool from which the establishment would obtain its vigor in the struggle against the "foreign" Jewish invasion. $^{23}$

Between 1922 and 1926, the number of university students in Bucharest and Jassy was 18,000 , four times higher than before the war. The student body was diverse and included war veterans along with the sons of emancipated peasants, expropriated landowners and middle-class families. Many among them became antagonized by the increase in the number of Jewish students and the prospect of them dominating the liberal professions. ${ }^{24}$ In 1922, out of the 136 students who completed their studies at the Faculty of Medicine in Cluj, only 64 were Romanian. ${ }^{25}$ Out of a total of 27,903 students enrolled during the 1926-1927 academic year, 4,390 were Jewish. ${ }^{26}$

In the fall of 1922, antisemitic unrest gripped the Faculty of Medicine in the Transylvanian city of Cluj, where the Christian students demanded that their Jewish colleagues conduct dissections on Jewish bodies despite Judaism prohibiting the practice in the majority of cases. ${ }^{27}$ They also ejected Jews from the campus and their dormitories before vandalizing the offices of a local Zionist newspaper where they also burned manuscripts and assaulted its editors and various journalists. One Jewish student was murdered and four seriously injured. The antisemitic uproar then spread to other universities, especially the ones in Jassy and Bucharest. In Jassy, Jewish stores remained closed on December 6 


\section{Introduction}

because of an antisemitic rally attended by 400 students. In Bucharest, between 3,000 and 4,000 students from all over the country assembled on December 10 at the Faculty of Medicine. They declared a general strike and made a series of demands. Their chief grievance was a numerus clausus, or the proportional representation of Romanian, Hungarian and Jewish students based on the demographic profile of the three ethnic groups in the country's general population. The measure would have affected the Jewish students in particular, as in 1930 they represented 14.2 percent of students but only 4.0 percent of the total population. ${ }^{28}$

The nationalist student generation which rose to prominence in 1922 received national attention not only because of its size and predisposition to violence, but also because it reflected in a disproportionate manner the grievances of mainstream nationalists and the majority of the Romanian ethnic population. The most pressing of their concerns was to create a purely Romanian elite with which to counter the assertive minorities in the new provinces, and to Romanianize the "foreign" cities. The nationalist student movement would go on to fill not only the ranks of the mature Iron Guard of the 1930s but also to shape the demographics of other fascist organizations such as the Liga pentru Apărarea Național Creștină (League for National Christian Defense), Fascia Națională (The National Fascio) and Acțiunea Românească (Romanian Action). ${ }^{29}$

Conceived initially as a principle aimed at curbing the access of Romanian Jews to the country's schools and universities, the numerus clausus became the new slogan of the antisemitic struggle. But it was only a preliminary phase to the next logical and ultimate step, the numerus nullus, or complete socio-economic exclusion. Fascist political organizations established in the early 1920s, such as the League for National Christian Defense led by A.C. Cuza, would become the most vociferous promoters of radical anti-Jewish measures such as the repeal of their political rights, the removal of those Jews who entered the country after 1914 , and their dismissal from the army and public offices. ${ }^{30}$

Cuza, a professor of political economy at the University of Jassy, was also the main advocate of Romanian fascism and a far-right theoretician who shaped the young generation of fascists, including his protégée Corneliu Zelea Codreanu. A law student until his expulsion in June 1921 for assault and vandalism, and one of the leaders of the student gangs, the Moldavian-born Codreanu travelled to Germany in 1922 to witness the antisemitic movement there and then imported organizational ideas back to Romania. ${ }^{31}$ In 1927 he founded the Legiunea Arhanghelului Mihail (Legion of the Archangel Michael) as an independent organization whose constituency was initially formed by students of the "22 generation" and later included teachers, priests, lawyers and military officers from the lower classes. A populist movement with pronounced mystical characteristics, the Legion was founded as a secret organization, a "blood brotherhood" with rituals borrowed from medieval Orthodox Christianity. From its onset the Legionary Movement had an anti-Jewish character and advocated for a categorical reaction against political life, especially democracy and liberalism, an ethnic "regeneration" by returning to Orthodox Christian values, as well as "salvation" through asceticism and sacrifice. The Legion, which in 1930 assumed the name 
Garda de Fier (Iron Guard) and in 1937 Totul Pentru Țară (Everything for the Fatherland), was the first Romanian fascist organization to introduce murder as a means of achieving its political goals. ${ }^{32}$

As was the case elsewhere in Europe, the economic turmoil triggered by the financial crisis of 1929 paved the way for further political radicalization in Romania. When A.C. Cuza's League for National Christian Defense merged with Octavian Goga's National Agrarian Party in 1935, they formed the National Christian Party, a mass political party which together with the Iron Guard would enjoy substantial political support in the 1930s. The National Christian Party's doctrine proclaimed a typically fascist anticommunism and antisemitism. Its political program called, among other things, for the arming of the country, the pre-eminence of the Church in the life of the State, a law restricting press freedom and the introduction of antisemitism as state policy. ${ }^{33}$

During the interwar years the press proved instrumental to fascist organizations such as the Iron Guard, who used it to disseminate their ideological programs. In 1932 the Iron Guard launched a regional press of its own, which a year later was producing 17 regional broadsheets. Certain intellectuals also committed to supporting the movement through their publications or literary activity. One of them was the ultranationalist publicist Nichifor Crainic (1889-1972), who pledged support in his Bucharest daily Calendarul (The Calendar, 1932-1933). ${ }^{34}$ After his adherence to the movement in 1933, the philosopher Nae Ionescu (1890-1940) used the newspaper Cuvântul (The Word), which he edited, to unreservedly endorse the Iron Guard. ${ }^{35}$ Historian of religion Mircea Eliade, philosopher Mircea Vulcănescu, literary historian P.P. Panaitescu, poet Radu Gyr and social scientist Traian Herseni are some of the cultural figures known to have absorbed the influence of the movement and advanced its cause. ${ }^{36}$

As the rest of Europe was undergoing political mutations that would soon have an irreversible impact upon inter-ethnic relations throughout the continent, interwar Romanian society was also transfiguring. The reflections of one of Romania's most important Jewish figures at the time help us grasp the magnitude of the changes taking place. Wilhelm Filderman, the leader of the Romanian Jewish community between 1919 and 1947, described the state of affairs in 1935 in the following terms:

Little by little, the anti-Semitic excesses became a collective psychosis. What had for years appeared to be isolated manifestations for which individuals or extremist groups were alone responsible now engulfed the whole society in Romania. Through the youth and the women, the most easily influenced segments, the entire nation seemed to gyrate around an unnamed folly. ${ }^{37}$

While racial thinking was gaining ground in the West by deriving its legitimacy from European colonialism, nationalistic ambitions and xenophobia, in Romania it did so for slightly different reasons. In this part of Eastern Europe it was nationbuilding and a fear of further Jewish immigration from Russia and Galicia that 
fueled the dissemination of racial antisemitism. ${ }^{38}$ The Jews in Romania started witnessing an increasingly hostile collective mindset directed toward them by their Christian counterparts. In their daily interactions they experienced the gradual erosion of interpersonal solidarity. Wilhelm Filderman denounced in unequivocal terms the state of the nation to which he was deeply attached:

The moral sense, the distinction between good and evil, was abandoned in the day-to-day relations between citizens. The voices of those who tried to utter an independent thought became quieter and were heard less frequently. A wave of hysteria took over public opinion. The atmosphere was poisoned by barbarous myths of "national purity," of "blood," of ritual murder. ${ }^{39}$

Benefiting from the increased fragmentation of the established political parties and the radicalization of Romanian society, during the 1937 parliamentary elections both the Everything for the Fatherland Party and the National Christian Party increased their electoral strength throughout the country, the former receiving 15.58 percent of the vote and the latter 9.15 percent. $^{40}$ Although it was meant to preclude electoral irregularities by the Gheorghe Tătărescu governing coalition, the non-aggression pact signed in 1937 between Iuliu Maniu, the leader of the more liberal Partidul Național Țărănesc (National Peasants' Party) and the Legion's leader, Corneliu Zelea Codreanu, had the effect of conferring respectability on the Iron Guard. ${ }^{41}$

In the elections' aftermath, King Carol II (1893-1953), the third monarch from the Romanian branch of the House of Hohenzollern-Sigmaringen that had reigned in Romania since 1866, appointed Octavian Goga as Prime Minister, despite his National Christian Party only having achieved fourth place in the 1937 elections. At Goga's request, in January 1938 Carol II dissolved the parliament for new elections. Since the Romanian parliament never convened during what became known as the Goga-Cuza government, Prime Minister Goga had to pass laws through emergency decrees, which in turn had to be countersigned by Carol II. One such decree aimed at removing the Jews' protection under the law. On January 21, 1938, King Carol II and Goga signed a decree authorizing the "review" of the citizenship of Romanian Jews based on racial criteria as well as geography, other conditions of birth and the possession of specific legal documents. The two claimed that between 250,000 and 500,000 Jews had illegal status. While Carol II claimed he did not intend to expel them, Goga proposed the deportation of "500,000 vagrants" to Madagascar. ${ }^{42}$

The attitude of the majority of Romanian Jews was to support the policy of the Union of Romanian Jews, the political organization which campaigned on their behalf and sought their integration. Its leader, Dr. Wilhelm Filderman, fought tirelessly to demonstrate the illegality of the anti-Jewish decrees and to obtain their abrogation. After 1937, Filderman together with other leaders decided that their response to the Romanian government's message toward the public, according to which emigration was the best way to solve the problematic relationship between Jews and Romanians, was to negotiate a feasible plan. Between December 1938 
and January 1939, intensive negotiations were held with government agencies and a joint committee was created to oversee all preparations for emigration. ${ }^{43}$

The campaigning for the March 2 elections commenced on February 6, 1938, under violent auspices. Clashes occurred between Iron Guard members, the fascist paramilitary movement Lăncieri who were affiliated with the National Christian Party, the Ministry of the Interior security forces and the police. The confrontations left two members of the Legion dead and 52 wounded, with 450 arrested. The agreement between Goga and Codreanu during their private meeting on February 8 established that the Iron Guard would keep its candidates for the election but withdraw and help the National Christian Party win. For Goga, the partnership with the Legion would signify an almost certain victory for the far-right at the elections while for Codreanu the collaboration would entail the Goga government's protection against Minister of the Interior Armand Călinescu and A.C. Cuza. The pact gave Carol II the excuse to impose Goga's resignation and declare the creation of a government of "national unity." Given the damage caused by the National Christian government to the Romanian parliamentary system, the Great Powers were prepared to witness the installation of a royal dictatorship. On February 11 Carol II proclaimed martial law and declared the 1923 constitution invalid. A new constitution published on February 20 strengthened the royal powers and subordinated the parliament to Carol's authority. ${ }^{44}$

In April 1938, Codreanu was arrested after insulting a royal minister, the historian Nicolae Iorga. Numerous other members of the Legion were also imprisoned. In May, a tribunal sentenced Codreanu to 10 years in prison for treason and inciting rebellion. The Legion's members who were still free in late 1938 and early 1939 escaped to Germany. Horia Sima (1907-1933), a member of the Legion since 1927, eventually assumed the leadership of the Legion, without Codreanu's consent. In November 1938 the Legion would begin a wave of violent terrorist actions. Two days after the failed assassination attempt against the University of Cluj chancellor, Codreanu was executed on the outskirts of Bucharest. ${ }^{45}$ After Codreanu's murder and the relocation of many of his followers to Germany, the movement became heavily influenced by the Nazis. However, the Germans perceived the authoritarian and increasingly pro-German Carol II as the most suitable guarantor of their interests in Romania. ${ }^{46}$

The incorporation of the Legionaries into the Romanian government was initiated by King Carol himself well before the Vienna Arbitration of August 1940 which brought an end to the regime. Initially Carol sought to extinguish the movement after Codreanu's execution and the Legion's assassination of Minister Armand Călinescu in September 1939. However, during the winter and spring of 1939-1940 Carol started a process of reconciliation with the movement, expecting it to produce greater support for the royal dictatorship. As for the Legion, many in Romanian society were convinced that it had full German support. But in the Führer's view the Legion was not capable of governing Romania by itself. ${ }^{47}$

Since senior German officials were still in agreement that Carol should remain on the Romanian throne, Sima reconciled with the Romanian monarch in May 1940, with the condition that Romania joined the Axis. Shortly after 


\section{Introduction}

the Soviet Union annexed Bessarabia and northern Bukovina on June 28, 1940, Horia Sima and two other members of the Legion entered the Gigurtu government but resigned a few days later after Sima's demand for a purely Legionary government was declined. ${ }^{48}$ Despite Ion Gigurtu's brief term as Prime Minister (July 4 - September 4, 1940), his government's policies marked Romania's shift toward fascism. The repressive measures pursued in July and August 1940 led to the internments in camps of 1,197 Communists, antifascists and leftist adherents recruited among the workers and intellectuals. ${ }^{49}$ In August 1940, Carol II approved Law No. 2650 which established new criteria for who was going to be considered a Jew, divided them into three categories and specified the degree of legal discrimination to which each was going to be subjected. A corollary law prohibited marriages between Romanians "by blood" and Jews. These legislative measures would constitute the foundation and serve as a landmark for the antisemitic legislation adopted later by the Antonescu-Sima and Antonescu regimes. ${ }^{50}$

Carol and his government were going to open negotiations with the Legion in order to try to reassure it of its re-entry into the government with increased Legionary participation, but the monarch's fall from power became imminent following the Second Vienna Award of August 30, 1940, during which northern Transylvania was ceded to Hungary. ${ }^{51}$ The arbitration also established that Romania had to make territorial concessions to its Axis-aligned neighbor, Bulgaria. Under the Treaty of Craiova of September 7, 1940, Romania reluctantly ceded the southern part of the region of Dubrudja, known as the Qadrilateral, which it had annexed in 1913, after Bulgaria's defeat in the Second Balkan War.

The negotiations concerning the territorial partition became the context in which Romania, acting on an ideological impulse, proposed to Bulgaria a population exchange. All ethnic Bulgarians from Romania were to be exchanged for all ethnic Romanians from Bulgaria. The initial estimates provided by the two countries indicated that 80,000 Bulgarians were residing in Romania and 69,080 Romanians in Bulgaria. The implementation of the population exchange was characterized by several setbacks such as the Bulgarian side's hesitating attitude based on humanitarian and pragmatic considerations and Romania's manipulation of the concept of ethnicity as well as the numbers of "ethnic Bulgarians" to be deported. By December 2, 1940, approximately 60,000 ethnic Bulgarians were resettled in Bulgaria, and 104,000 ethnic Romanians relocated to Romania. A second, smoother exchange took place in May-June 1941, when 3,153 Bulgarians living in Romania and 3,689 Romanians residing in Bulgaria were resettled. ${ }^{52}$

Carol's reluctance to enforce the Vienna Award in exchange for the Axis's guarantee of Romania's territorial integrity caused a change in the official German attitude toward the Romanian monarch. At home, the royal dictatorship lost all support among the public, the army and the political class. Pro-German members of Carol's entourage and some among the ministers saw in Army General Ion Antonescu a highly desirable option for the leadership of the country. Following the reassurances received from certain members of the Romanian establishment, the Nazi officials in Berlin agreed that Antonescu should be granted full powers by the King. On September 5, Carol agreed to restrict himself to ceremonial duties. ${ }^{53}$ 
Following extensive negotiations between Horia Sima and Ion Antonescu, the National Legionary State (September 14, 1940 - February 14, 1941) was established. The legionaries occupied senior governmental positions and members of the organization became prefects of Romania's 50 administrative districts. A month into the alliance, uniformed legionaries marched in front of the royal palace, where representatives of each section of the Legion presented themselves before Horia Sima and General Antonescu, singing songs specific to their unit. ${ }^{54}$ The Legionary movement became the only political movement recognized in the new state in which the Constitution was suspended and Parliament dissolved. The fascist dictatorship also took measures against the former dignitaries of the monarchy and created economic commissions for Romanianization. ${ }^{55}$

Antonescu's alliance with the Iron Guard was of major concern to the Jewish leadership in Romania. Wilhelm Filderman delivered a memorandum to the new head of state in which he urged Antonescu to take into consideration the situation of 80,000 Jews who had been targeted by the recent restrictive legislation as well as the dire condition of the Bessarabian and Bukovinian refugees who were facing imminent starvation. Filderman reaffirmed the Romanian Jews' favorable stance in relation to the emigration plan but pleaded for the adjustment of the proposed emigration figures in line with the diminished size of the general population following the Soviet Union's annexation of Bessarabia and northern Bukovina. Filderman added that he saw fit for the plan to be implemented only after the end of the war. Meanwhile, Zionist organizations in Romania were opening training schools for Jews willing to emigrate to Palestine. Aware of the government's real intentions, the Romanian Jewish leadership started pressuring the Jewish Agency and the British ambassador for a larger number of immigration certificates for Romanian Jews. Despite the constant increase in the numbers of Jews wishing to leave Romania, the possibilities for legal immigration into Palestine were narrowing. ${ }^{56}$

Antonescu needed the Legion, given that his support was limited to that from senior politicians, certain sections of the army and the German ambassador to Romania at the time, Wilhelm Fabricius. While Antonescu's popular support base was thin, the Legion was benefiting from considerable public endorsement. It also secured the support of middle- and lower-ranking army officers. If the General was to preserve and consolidate his position as Minister President, it was very important that he forged links with the popular movement. ${ }^{57}$ However, immediately after they rose to power, the members of the Legion became responsible for a plethora of abuses and socially disruptive practices. The Legion's members engaged in a concerted assault on the Jews throughout the country. The legionaries would search homes, arrest suspects, demand their files from local polices stations, stand guard outside Jewish stores, inspect merchandise and track down police officers who had persecuted legionaries in the past. They also searched the homes of suspected Freemasons, destroying property and threatening children with their weapons. Gendarmes complained that legionaries mistreated them and refused to recognize their authority. The regime created a formal legionary police force in October, which was disbanded shortly after due to their disorderly conduct and clashes with the professional police. Legionaries also engaged in petty 


\section{Introduction}

theft and invaded lumberyards and grain and wheat silos, giving away their contents for free. They requisitioned buildings, cars and furniture for legionary use. The Legion's members drove non-legionary professors from their university posts and appointed academics affiliated with the movement. Legionary values became law and those responsible for the various abuses interpreted them as charity ${ }_{.}^{58}$

Building on the restrictions of civil rights and economic marginalization of the Jews during the Goga-Cuza administration, and without being pressured to do so by Berlin or the German legation in Bucharest, the National-Legionary government passed antisemitic legislation which aimed at the Romanianization of Jewish property, namely the expropriation of Jewish-owned property on behalf of the state or ethnic Romanians, the dismissal of Jews from their occupations and their replacement by Romanians, especially the 300,000 or so who had fled the territories lost to the Soviet Union, Hungary and Bulgaria, and the exclusion of Jews from Romanian intellectual and cultural life. Laws were also passed dismissing Jews from the Romanian army, expelling Jewish pupils from Romanian state schools and creating new ones exclusively for Jews. The home-grown variety of anti-Jewish laws was complemented by administrative measures adopted by government ministries, local government institutions and even voluntary associations. ${ }^{59}$

Despite acting convergently with the Legion in regard to the disenfranchisement of the Romanian Jews, Antonescu became antagonized by the legionaries' disrespect for order and legality. Some legionaries also started distancing themselves from the regime. The murder of 65 political prisoners at the Jilava prison on November 26 and the assassinations of historian and politician Nicolae Iorga and politician Virgil Madgearu in their homes later the same night overstrained the relationship between the two allies of the National Legionary State. ${ }^{60}$ On January 21 , the legionaries staged a rebellion against General Antonescu with reverberations to different degrees throughout the country. In Bucharest the legionaries occupied numerous facilities and public institutions, disarmed numerous policemen and ultimately engaged in open conflict with the army. It took the latter three days to defeat and arrest the rebels. However, it could not prevent some of the atrocious acts committed against the local Jewish population. Legionaries started arresting Jews on January 20. The following day, legionary gangs stormed Bucharest's two main Jewish boroughs where they loaded into trucks approximately 2,000 Jews, including the elderly and children, and sent them to preestablished sites. There they were beaten, raped and tortured. Christian factory workers aged between 15 and 25 tortured Jews at the police precinct on Matei Basarab Street while another 200 Jews were detained and treated with utmost sadism at the CML headquarters. After the rebellion was extinguished, the naked and mutilated bodies of 84 Jews could be seen in the forest near Jilava. Bucharest's largest synagogues were devastated and a total of 1,274 buildings including 25 synagogues, 616 shops and 547 homes, were both vandalized and pillaged. Two hundred trucks loaded with stolen goods from the Jews were subsequently discovered by the authorities. ${ }^{61}$

The differences between Ion Antonescu and the Legion were not of ideology but pertained to the struggle for power and reflected divergent outlooks on how 
the Romanian fascist state should be governed. Despite his fascist proclivities, Antonescu's military mindset opposed the legionaries' administrative and economic chaos as well as their greed and incompetence. It was not the murder of high-ranking dignitaries that vexed Antonescu but the open defiance of his authority as the head of the governmental justice system. ${ }^{62}$ The Iron Guard had been the sole radical movement of the Right in Europe to come to power without the assistance of Germany or Italy, and the only one to be ousted during Nazi Germany's domination of continental Europe. ${ }^{63}$

On January 27, 1941 Ion Antonescu appointed a new cabinet composed almost entirely of officers. He established a military regime under which senior officers received orders only from him, and usually bypassed the other ministers in the government. The only formal body to assemble on a regular basis was the Council of Ministers chaired by Antonescu, which had no legislative or other statutory powers and served as a forum where various ministers would report on the activity of their ministries. The decisions were not reached collectively but unilaterally by Antonescu. The lack of broad accountability remained a central feature of the entire Antonescu administration. In the beginning, Antonescu received the approval of the democratic parties whose stance was driven by pragmatism and who regarded the military government as the best solution at the time given the external and internal conditions. ${ }^{64}$ During his rule, Antonescu would also secure the support of the Romanian bourgeoisie, namely the industrialists, capitalists, shareholders and large factory owners, who despite the economic compromises Romania would have to make to Germany, benefited from Antonescu's Romanianization policy which removed competition by skilled professionals, provided them with ownership of Jewish factories, companies and businesses and ultimately enriched them. ${ }^{65}$

Convinced that the Romanian economy was under Jewish monopoly, Antonescu did not reverse the Goga-Cuza administration or the Legionary government's anti-Jewish legislation but pursued the Romanianization policies further. Thousands of Jewish workers and professionals lost their livelihoods following their dismissal from their professions and workplaces. In April 1941 Antonescu crafted the measure which outlawed intermarriages between civil servants and Jews or anyone who was not of Romanian ethnicity. Separate laws prescribed the expropriation of urban buildings belonging to Jews and the confiscation of Jewish apartments. Both the premise and the outcome of these policies was the creation of a parallel system of justice: one for Romanian ethnics and one for Jews. ${ }^{66}$

As a result of the intensification of anti-Jewish persecution, larger numbers of Romanian Jews regarded emigration as a collective imperative. With Nazi Germany's approval, Romania tolerated illegal emigration in its territorial waters until the end of 1941. It also hoped that the movement would expand to include not only the Polish Jews who sought refuge in Romania at the beginning of the war or the Bukovinian and Bessarabian Jews who fled the Soviet annexation. In March 1941 the Romanian Jewish leadership offered to centralize the immigration procedures under România, the official tourism company, and presented a number of ways to expedite the process and maximize the number of immigrants departing through the Romanian ports. ${ }^{67}$ 
Despite the consistent pursuit of antisemitic policies by the Antonescu regime following the establishment of the military dictatorship, in early 1941 there was no systematic and centralized blueprint for the anti-Jewish violence about to be unleashed. Antonescu's main concern remained the Soviet Union and the prospect of a Russian invasion of Romania. He was also aware of the partitions Nazi Germany was initiating and the territorial concessions it was making to some of Romania's neighbors such as Hungary and Bulgaria. As Nazi Germany was preparing the invasion of the Soviet Union, Hitler was still deliberating about the roles his allies would be playing but planned to share no important details with Antonescu, or with the Finnish or Hungarian governments, until the very last moment. ${ }^{68}$

From the Nazi leadership's perspective, Antonescu's domestic achievements of restoring order, observing his economic obligations to Germany and demonstrating his ability to fill the political void left by the Legionaries in the absence of another fascist party, were reassuring. The intensity of Romanian nationalism along with the oppression of Jews and Communists compensated for the absence of a formally fascist party. Nevertheless, between February and June 1941, Antonescu's policy and the military government arrived at a turning point which made possible the upcoming radicalization in the treatment of the Jews. Antonescu found himself increasingly under the influence of the Führer and identified more with the Nazi regime as the opposite of democratic liberalism. The Romanian leader also felt compelled to contend with the antisemitic Legionary legacy. Immediate realities such as the preparations which were being made in Germany for the implementation of the Final Solution and the drastically increased presence in Romania of the German military, whose expeditionary force numbered 680,000 soldiers, were also predisposing factors. ${ }^{69}$

Antonescu's readiness to participate in Operation Barbarossa was not motivated solely by the ambition to settle a score with the Soviet Union. For him the German offensive represented an ideological campaign against the heresy of Communism, and his involvement in its eradication was an act of Christian righteousness. ${ }^{70}$ The war against the Soviet Union would unleash an ideological climate of a bellicose, chauvinistic and xenophobic nature. Imperialistic aspirations and a wave of lies were being propagated nation-wide by the radio, the press, the schools, the churches and the corridors of political power. ${ }^{71}$ Antonescu and the Romanian authorities' attitude toward the Jews changed substantially following his return from Berlin, where he visited Hitler on June 12, 1941, to conclude the political and military arrangement for the campaign against the Soviet Union and returned convinced of Germany's military triumph. Earlier that year, a mission of the Reich Main Security Office (RSHA), which coordinated the security services of Nazi Germany and the Nazi Party, and also oversaw the paramilitary death squads, Einsatzgruppen, visited Romania. It is assumed that both developments influenced Antonescu to conceive his own approach regarding the solution to the Jewish problem in Bukovina and Bessarabia. ${ }^{72}$

Antonescu regarded the Jews, especially those in the borderlands, as a fifth column. In an open letter addressed to the President of the Jewish community, 
Antonescu stated that, "Even before the appearance of the Soviet troops, the Jews of Bessarabia and Bukovina spat upon our officers, they tore their uniforms, and when they had the chance, the cowards beat our soldiers to death with cudgels. ${ }^{.73} \mathrm{He}$ held the Jews responsible for Romania's humiliation a year before when it received the Soviet ultimatum and was forced to withdraw from northern Bukovina and Bessarabia. In 1940, when the Romanian army was given three days to leave only to discover that the Soviet troops disregarded the deadline and entered the country before June 29 , both popular propaganda and official reports recurrently employed the notion of the Jewish Communist, saboteur and foe of the Romanian nation. Massacres committed by Romanian soldiers, as well as Romanian and Ukrainian mobs, occurred especially in Bukovina. In neighboring Moldavia, soldiers, policemen, townspeople and peasants perpetrated numerous killings. Jews were thrown from moving trains or butchered in their hometowns. The Dorohoi pogrom, which was not driven from above but took the form of uncoordinated local military initiatives and antisemitic agitation, left up to 200 Jews dead. ${ }^{74}$

War-related developments continued to shape local dynamics in which military and civilian actors perpetrated unprecedented atrocities against the Jews. On June 24, 1941, the day that Romania declared war on the Soviet Union, Soviet planes bombed Jassy. A second bombing raid occurred on June 26 and caused numerous fatalities, seriously damaging telecommunications lines as well as one military and a civilian facility. According to rumors that emerged shortly afterward, not only were Jews responsible for pointing out targets to the pilots, but the pilots themselves were Jewish. Anti-Jewish sentiment had already been evident in Jassy since June 20 in the form of intensified public harassment of Jews, articles published in local newspapers calling for the re-annexation of Bukovina and Bessarabia and for vengeful action on behalf of those humiliated by Jews during the withdrawal of 1940, placards appearing throughout the city accusing the Jews of starting the war, the dissemination of rumors and official reports depicting Jews as armed and active in indicating the locations of targets to Soviet pilots, and the order received by a compulsory labor crew of 110 young Jews to prepare two large ditches in the Păcurari Jewish Cemetery. ${ }^{75}$

On June 27, the military and local police officially accused the Jewish population of collaboration with the Soviet regime. Despite local Jewish leaders providing the authorities with evidence that several dozen Jews were also among the dead and that Jewish property was also damaged during the Soviet bombardment, the military and local police did nothing to curb the heightened antisemitic hysteria. That same day, a mass execution took place at Stânca Roșnovanu, five miles (eight kilometers) north of Jassy. The joint German-Romanian operation targeted the Jewish community of Sculeni, a town close to the front line, and massacred 311 of its inhabitants after a former mayor was borrowed from a nearby artillery unit to separate Jews from Christians. ${ }^{76}$

During the night of June 27-28, a staged attack on Romanian and German troops was intended to demonstrate the efficiency of Jewish terrorist activity in Jassy, and to serve as pretext for a general assault on the city's Jewish inhabitants. 
Romanian municipal and military police, soldiers, gendarmes and German units pulled Jews from shelters, executing many on the spot and taking the rest to the police headquarters. The next day, Jewish men, as well as some women and children, were taken out of their homes and marched off to the police headquarters and other locations. Anyone who resisted was beaten or shot. Local civilians joined the main perpetrators. A large number of Jews were detained in the courtyard of the police headquarters. A mass execution of approximately 5,000 people started in the afternoon at the police headquarters and in the surrounding streets. In the execution's aftermath, roundups continued. Christian households were marked with crosses, and some displayed signs stating Christian ownership and that no Jews could be found in the courtyards. A number of non-Jews warned the victims or tried to prevent the killings, some paying with their lives. ${ }^{77}$

At Antonescu's order to evacuate the entire Jewish population of Jassy, on the night of June 29, 2,530 survivors of the massacre at the police headquarters were marched to the train station, flanked by two German tanks. They were loaded into the freight cars of a train bound for Călărași, a city in the south-east of the country. The train headed in the direction of Târgu Frumos, 30 miles (48 kilometers) west of Jassy, with its shutters boarded up or locked. It stopped at some stations and passed through others. Instead of covering 30 miles (48 kilometers) in one hour, the journey lasted 17 hours and covered 125 miles (200 kilometers). The first train arrived at its final destination on July 6. After multiple dead bodies were unloaded during previous stops, the train arrived in Călărași with 1,011 Jews alive and approximately 100 dead or near death. A second train was loaded with 1,902 people from those who had been detained in various sections of the police headquarters, at the grounds of the Legion of Gendarmes or picked up during the raids that followed the collective execution. It was sent to Podu Iloaei, 18 miles (30 kilometers) west of Jassy, being driven slowly back and forth, with conditions inside its carriages even worse than in the first train. Those alive when the train finally stopped numbered 708; there were 1,194 dead. ${ }^{78}$

Antonescu initially accepted the army's explanation, according to which the Jews shot at the troops and thus deserved the retaliation, but later reassessed the events as shameful for the army, whose soldiers were animated by the desire to loot or maltreat. He asserted that the government alone had the right to implement repressive measures and demanded a new investigation. These facts suggest that the most plausible interpretation of the massacre in Jassy is as a product of chaos, violence and loss of control by the authorities, who were prevented by their own metabolization of antisemitic propaganda from properly assessing the situation. ${ }^{79}$

In the aftermath of the Jassy massacre, the antisemitic violence committed by the military authorities, often with the cooperation of groups of local civilians, did not relent but instead acquired new dimensions. On June 17 and 18, 1941, the leaders of the gendarmerie organized regional conferences in Galaţi and Roman, where various gendarme legions received the order from the Inspector General of the Gendarmerie, General C.Z. Vasiliu, to "cleanse the land" of Jews. The order specified the "extermination on site of all Jews found in rural areas," the concentration into ghettos of those in the towns, and the arrest of all "suspects," 
Communist party members and those who had held office under the Soviet occupation. ${ }^{80}$ Similar instructions were given by Deputy Prime Minister Mihai Antonescu to the administration of the liberated provinces on July 3, 1941. They were followed by an equally radical message delivered during a cabinet session on July 8:

At the risk of not being understood by traditionalists...I am for the forced migration of the entire Jewish element of Bessarabia and Bukovina, which must be dumped across the border...You must be merciless to them...I don't know how many centuries must pass before the Romanian people shall again encounter such total liberty of action, such opportunity for ethnic cleansing and national revision... This is a period in which we are masters of our land. Let's use [this opportunity]. If necessary, use your machine guns. I couldn't care less if history remembers us as barbarians...I take formal responsibility in telling you there is no law...So, no formalities, complete freedom. ${ }^{81}$

On June 21, the entire Einsatzgruppe D, one of the four Einsatzgruppen which operated in Soviet territory, left Düben in Germany and arrived in Romania three days later, charged with overseeing the liquidation of the Jews within the area south of Cernăuți and Mogilev-Podolski to the Black Sea, including the future region of Transnistria. ${ }^{82}$ The Abmachungen (agreement of field cooperation) had been reached by Mihai Antonescu, the SS and other German bodies. The Einsatzgruppe D's relationship with their Romanian partners would be marked by the former's perpetual discontent with the imperfect implementation of various plans by the latter. A wide range of German military documents focused not on the perpetration of the crimes but on the spontaneous and chaotic manner in which different Romanian forces were committing them. ${ }^{83}$

On July 3, the Romanian army launched a general offensive against northern Bukovina and by July 26 it reached the Dniester river. Officially, Antonescu was supreme commander of the German and Romanian forces on the Romanian front, a title he received from Hitler in Munich on June 12, 1941. ${ }^{84}$ In recognition of the recovery of the two regions, King Michael I (1921-2017) promoted Antonescu on August 22, 1941, to the rank of Marshal. As for the international reaction, Great Britain and the United States did not denounce Romania right away, but to British public opinion Romania was already an enemy state. Inside Romania, the majority of political leaders endorsed the re-annexation but insisted that Antonescu should not go beyond the country's historical frontiers. ${ }^{85}$

Within the newly recovered regions of northern Bukovina and Bessarabia, the repressive measures against the Jewish population were nothing but an emanation of Marshal Antonescu's will. The implementation of the repressive measures in the two regions came in the form of a written order to the army and gendarmerie given by the General Staff. The plan was to "remove the Judaic element (...) by organizing teams to act in advance of the Romanian troops." These teams' mission was "to create in villages an unfavorable atmosphere toward the Judaic elements, thereby encouraging the population to...remove them on its own, by whatever 
means it finds most appropriate and suited to the circumstances." ${ }^{96}$ These special teams recruited Romanians from Bessarabia with valid Soviet documents and families living in Romania, which guaranteed their reliability in completing the assignments. The teams were sent along nine parallel routes in Bessarabia to provoke the peasants against the Jews and encourage them to loot, rape and kill. ${ }^{87}$

Soon after the directive announcing the physical elimination of the Jews was disseminated among both military and civilian officials in the two regions, the majority of the Christian population in Bessarabia and Bukovina was aware of the Jews' fate as well as the written directive's encouragement that the local population should do as they wished with the Jews' lives and property "within the first 24 hours of the occupation." According to the postwar testimonies of Christian witnesses, the dispensation was three days ${ }^{88}$ The assault about to unfold represented the fulfilment of Antonescu's murderous strategy which he shared with the Council of Ministers on April 21, 1941: "I let the crowd loose to massacre them, then I retire into my fortress and, once the massacre is over, I restore order." ${ }^{\prime 9}$

In Bukovina, Christian locals began participating in anti-Jewish violence as soon as their localities were liberated in early July. This was the case in the village of Ciudei, where the Romanian army arrived on July 3 . The same day, between 450 and 572 Jews were murdered. Similar events occurred on July 4 in the city of Storojineț where Romanian troops and local inhabitants massacred 200 Jews in two days. On July 5, state-sponsored and popular violence decimated entire Jewish communities in all villages of the Storojineț district. Large-scale atrocities proliferated throughout northern Bukovina, causing massive loss of life among the Jewish population living in Vijnița, Sadagura and Cernăuți. ${ }^{90}$ In Bessarabia the liquidation of entire Jewish communities was achieved within a matter of days, despite the magnitude of the task, resistance by Soviet troops and difficulties posed by the physical terrain. Thousands of Jews were exterminated in the towns of Briceni, Lipcani, Fălești, Mărculești and Florești, as well as the villages Gura-Camenca and Gura-Căinari. On July 17, several thousand Jews were killed in Chișinău, the largest Jewish center in the region. ${ }^{91}$

Toward the end of July, the Romanian troops sent convoys of thousands of Jews toward the Dniester and into the rear of the German front. These premature deportations forced the German troops to push the deportees back into Bessarabia and antagonized the German military authorities. During their transfer to and from the Ukrainian territory, many Jewish deportees were robbed, raped or shot, or died of illness and starvation. Pending the resumption of deportations, the Romanian authorities established a network of transit camps and ghettos. From there, the authorities sent the Jews to seven major camps and created the ghetto in Chișinău. By late August, 80,000 Jews were confined in the Secureni, Edineți, Limbenii Noi, Rășcani, Răuțel, Vertujeni, Mărculești and Chișinău camps. Between 5,000 and 6,000 Jews were in smaller sites in southern Bessarabia. ${ }^{92}$

On August 30, 1941, Germany formally awarded Romania with the region of Transnistria for administration, security matters and economic exploitation purposes. Transnistria was the name given to a part of the Ukrainian territory which stretched over 40,000 square kilometers and had a population of three million 
people, according to the Soviet census of 1939. The majority were Ukrainian and Russian. The three next largest minorities were Jewish, Romanian and German. Transnistria was a fertile land with rich arable soil for growing wheat, corn, vines, fruit and tobacco. The southern city of Odessa was its natural capital. Despite the occupation regime being formally inaugurated at Tiraspol on August 9, the Romanian administration settled in Transnistria only after the occupation of Odessa on October 16, 1941. The head of the administration was Gheorghe Alexianu, a law professor and notorious antisemite, who was assisted by a secretary general and 19 ministers. ${ }^{93}$

Odessa was defenseless and devoid of armed forces when the Romanian and German troops entered the city. However, before they withdrew, the Soviets blew up and mined factories and installations that could not be evacuated. The antisemitic mood, especially in the working-class neighborhoods, greatly intensified during the siege. On the first night of occupation, the Romanian forces massacred a large number of local Jews. All the male population had to report to checkpoints set up in schools and public buildings. Many Jewish men and boys were ordered to remove rubble throughout the city. Inspired by the practice of their German partners, on October 18 the Romanian forces began taking hostages in order to maintain calm in the city. Many of the hostages were Jews who were either evicted from their homes or who had reported to the checkpoints. ${ }^{94}$

On the evening of October 22, an explosion triggered by a radio-controlled mine reduced to ruins the Romanian military general headquarters, killing 66 people including a number of Romanian officers and the city's military commander. The building had previously served as the headquarters of the NKVD (the Soviet secret police). The reprisals focused on Odessa's Jewish population after the regime in Bucharest classified the incident as an act premeditated and implemented by local Jewish Communists. Despite the offer made by the Germans to dispatch an SS regiment to the help the Romanians, the latter decided to act independently. Romanian soldiers and military gendarmes began shooting at Jews in the streets and hanging them on tram posts, at street corners or on balconies facing the main streets. Multiple executions occurred in the main penitentiary and in Dalnic, a village nearby, where approximately 25,000 Jews were taken. Antonescu ordered that all the remaining Bessarabian Jews who had sought refuge in Odessa should be forced into buildings containing explosives. About 22,000 Jews of different ages were herded into nine large warehouses which were fired at with machine guns, set ablaze and blown up. ${ }^{95}$

Antonescu envisaged that the occupation of Transnistria would continue indefinitely. In the government session of December 16, 1941, he urged Alexianu to "govern there as if Romania had been ruling these territories for two million years. What will happen afterward, we'll see...Y You are the sovereign there. Force people to work - with a whip if they don't understand otherwise...and if necessary, and there is no other way, prod them with bullets; for that you don't need my authority." 96 Article 7 of the agreement between the Romanian General Staff and the Wehrmacht specified that for the time being the Jews could not be transported across the Bug river [Transnistria's border in the northeast]. They were to 


\section{Introduction}

be placed in labor camps and forced to work until the war ended, and they could be evacuated to the East. ${ }^{97}$

The deportations began on September 16, 1941. The five major crossing points from Bessarabia into Transnistria were, from north to south: Atachi-Moghliev Podolski, Cosăuți-Yampol, Rezina-Râbnița, Tighina-Tiraspol and Olănești-Iasca. ${ }^{98}$ The Bessarabian Jews were sent to Transnistria from the Mărculești and Vertujeni camps and the Chișinău ghetto, as well as from the ghettos in Orhei, Cahul, Ismail, Vâlcov, Chilia Nouă and Bolgrad. ${ }^{99}$ In October, the Bukovinian Jews were deported starting with those from the southern part of the region followed by those in the Cernăuți and Storojineț ghettos. In November, 12,000 Jews from the Dorohoi district were also sent to Transnistria. The second phase of the Holocaust concluded in mid-December 1941, with the departure of the last convoys of Jews from southern Bukovina and the Dorohoi district. A second wave of deportations would take place in the summer of $1942 .{ }^{100}$

In Transnistria, the Bukovinian and Bessarabian Jews were dispersed across various districts. They often slept in stables or pigsties, sometimes not allowed to use even straw. Many survived by begging or selling their clothes for food, which left them almost naked. They experienced an erratic food distribution and had to eat leaves, grass and potato peelings. In December 1941 there were 56,000 Romanian Jews in the Moghilev county, near the Dniester river. Despite its precarious hygienic conditions, this was the county in Transnistria with the highest survival rate which it owed to a more infrequent German presence and involvement as well as to the resourcefulness of the Jewish community in the town of Moghilev. ${ }^{101}$

In Golta county, a large number of Jews were confined in three impromptu camps: Bogdanovka, Domanovka and Akmecetka. At Bogdanovka there were 48,000 Jews, the majority from Odessa and several thousand from southern Bessarabia. The 18,000 Jews at Domanovka were gathered from three districts in the south of Transnistria, while the 4,000 at Akmecetka were the sick, elderly and women, classified by the local authorities unfit for labor. In late November 1941, overcrowding and the spread of typhus led to an increase in the death rate. By mid-December the number of daily deaths rose from between 50 and 100, to 500 a day. Despite the conditions in these camps, convoys of Jews continued to arrive and the contact between the sick and the local Ukrainian population who would travel to the camps to sell food, as well as between the detainees and the Ukrainian militia and the Romanian gendarmes who guarded the camp, contributed to the propagation of the disease. Following the order delivered verbally by governor Alexianu, the county of Golta's military authorities ordered a number of 70 Ukrainian policemen to execute the 48,000 Jews of Bogdanovka. Approximately 5,000 Jews were doused with petrol and then torched. The remaining 43,000 were taken to a nearby forest where they were shot during an operation which lasted several days. The bodies were cremated throughout January and February 1942. Fearing the spread of disease, the Romanian authorities instructed local Ukrainian policemen to also execute 18,000 detainees at Domanevka. After thousands of detainees died of disease and hunger at Akmecetka, the camp became the final 
destination for the sick and emaciated from other sites who were sent there to die a slow death. ${ }^{102}$

In January 1942, the typhus epidemic reached catastrophic proportions and countless Jewish deportees died during the winter of 1941-1942. The extreme cold made the burial of the corpses impossible and fueled the spread of the illness. As if disease, lack of food, clothes and shelter were not adverse enough conditions for the Bukovinian and Bessarabian Jews, the authorities often exploited the deportees through forced labor. The ordeal of approximately 2,000 Jews from Dorohoi and Cernăuți who worked in a stone quarry under very harsh conditions is one such example. ${ }^{103}$ When the typhus epidemic in the Transnistrian camps and ghettos was completely eradicated in June 1942, it was in part due to self-help activities in the ghettos. The Jewish Committees which existed in some ghettos (mostly in Mogilev county) played an instrumental role in the fight against the epidemic. Many Jewish doctors lost their lives trying to contain the outbreak. By the summer of 1942, approximately 34,500 Jews had died of typhus. ${ }^{104}$

In May 1942 Antonescu ordered the deportation to Transnistria of those Jews who were active Communists, those who were clandestine in Bucharest, the ones interned in the Târgu-Jiu camp and those who were in prison serving sentences handed down by the courts. In July a few other offences were added to the previously established categories of prospective deportees. The order affected Jews from the Old Kingdom, Banat and southern Transylvania. On September 8, 1942, 407 Jews who were branded as Communists and interned in Târgu-Jiu, along with 80 Jews from the Jilava prison near Bucharest and 600 Jewish Communist activists gathered from all over Romania, were deported to Vapniarka, one of the two camps in Transnistria. There, the detainees were fed a variety of pea that was used for cattle fodder and causes paralysis in humans. As a result, several dozen inmates suffered paralysis in their lower limbs, with more than 400 showing signs of advanced paralysis. There were 139 cases of irreversible paralysis before orders were given for the internees not to be fed the peas. ${ }^{105}$ At the other camp, Peciora, where the signpost above the entrance displayed the words "death camp," survivors described how inmates had to eat human waste and feed on corpses. Peciora was the most dreadful site of Jewish internment, with a survival rate of only 20 percent. ${ }^{106}$

If mass removal to Transnistria represented the Antonescu regime's solution to the "Jewish question" in the borderland regions of Bukovina and Bessarabia, deportation to the extermination camps in Poland was the course of action intended by the Romanian authorities in regard to the Jews in the Old Kingdom and southern Transylvania. From 1941 until 1944, the fate of the Romanian Jews depended exclusively on whether Antonescu considered them useful to Romanian national interests or not. Antonescu was resolute in his pledge to make Romania homogeneous. In the summer and fall of 1941, the secret negotiations with Gustav Richter, the Nazi advisor for Jewish affairs, and the German government concerning the deportation of the Romanian Jewry to the Bełżec camp in Poland were approaching their conclusion. Except for 17,000 Jews regarded as indispensable to the Romanian economy, the Antonescu government agreed to deport 
the entire Jewish minority of Romania, which according to the May 1942 census was 292,149 people. However, in October 1942 the Romanian government announced the suspension of the deportations of Jews to Transnistria and Poland. This was for pragmatic rather than humanitarian reasons. ${ }^{107}$ The evolution of the war had changed the government's attitude toward the deported Jews, providing Ion Antonescu with an opportunity for opportunism. ${ }^{108}$

The partial repatriation of the Romanian Jews deported to Transnistria began in the second half of December 1943 when 6,000 Jews from Dorohoi were allowed to return to their hometown. In March 1944, 1,846 children of the 5,000 Jewish orphans were also repatriated. That same month Antonescu ordered general repatriations. The joint efforts of the Jewish community and the Romanian authorities led to the repatriation of 2,538 people from various camps and ghettos in Transnistria. The situation of tens of thousands of deportees left in Transnistria remained difficult to clarify despite the desperate efforts of the Jewish leadership in Bucharest to obtain general repatriation decision from the Romanian authorities as early as possible. ${ }^{109}$

Between 280,000 and 380,000 Jews were murdered or perished during the Holocaust in Romania and the territories under its administration. Between 45,000 and 60,000 Jews were murdered in Bukovina and Bessarabia by Romanian and German armed forces in 1941. Between 105,000 and 120,000 Romanian Jews died as a consequence of their deportation to Transnistria. In Transnistria, between 115,000 and 180,000 Ukrainian Jews were murdered during Romanian rule. At least 15,000 Jews from the Old Kingdom were murdered during the Jassy pogrom and following other anti-Jewish measures. From Hungarian-occupied northern Transylvania, approximately 132,000 Jews were deported to Auschwitz in May-June 1944. ${ }^{110}$

Not only was the Antonescu regime responsible for the systematic elimination of a large segment of the Romanian and Ukrainian Jewry but, as the war progressed, the Romanian military dictator also decided to pursue measures against the Roma population. According to the 1930 census, there were 262,501 people who declared themselves to be of Gypsy descent, or 1.5 percent of the population. Some worked as craftsmen and farmers while others became involved in community affairs and even established Roma associations. During the interwar period their relations with the majority were positive despite prejudices and stereotypes inherited from the centuries of slavery. A large number assimilated into the majority culture. During the 1930s, Romanian researchers who became influenced by Nazi theorists of eugenics, racialized the Roma and depicted them as a threat to the "racial purity" of Romanians. Despite there not being a plan in the beginning to deport the Roma population to Transnistria, following the census conducted in May 1942 throughout the country by the Romanian gendarmerie and police, several categories of "problem" Roma were created upon Antonescu's orders. The nomadic Roma, as well as those with a criminal record, recidivists and those without an occupation or means of subsistence from the category of sedentary Roma, were placed under surveillance. Soon after, Antonescu's ethnic policy led to the deportation of 11,441 nomadic Roma to Transnistria between June and 
October 1942. In September 1942, 13,176 sedentary Roma who were classified as "undesirable" were also sent across the Dniester river. The last transport of Roma to Transnistria took place in December 1943, when 57 people from southern Romania were deported. Out of the 25,000 Roma deported to Transnistria, approximately 11,000 died. ${ }^{111}$

In addition to the victimization of the Jewish and Roma minorities, the Antonescu regime also persecuted the neo-Protestant sects for their conscientious objection to military service. During the interwar years the sects succeeded in creating a membership composed primarily of peasants who previously adhered to the Orthodox Church. The individual unauthorized sects whose worshippers were in the hundreds rather than thousands were perceived as a significant enough threat. In August 1942, approximately 2,000 neo-Protestants were deported to Transnistria. ${ }^{12}$

On August 23, 1944, Ion Antonescu was overthrown by King Michael I during a coup which received the support of several political parties. General Sănătescu, who enjoyed the respect of the army, was appointed as prime minister to replace Mihai Antonescu. Shortly after, the Romanian troops were ordered to halt hostilities against the Soviet army at the front. Not a single senior officer disobeyed the orders and there was no defection to the Marshal. Despite King Michael's intention to deliver Ion and Mihai Antonescu to the Nuremberg Tribunal and thus spare them the death penalty, in May 1946 Ion Antonescu and 23 others were tried in Bucharest where they stood accused for 'bringing disaster upon the country' and 'the crime of war'. At the end of a ten-day trial, a Communist-led tribunal found Antonescu and six of his associates guilty and sentenced them to death. Ten other defendants received prison sentences. ${ }^{113}$

\section{State of research}

My study intends to expand and deepen the understanding of the involvement of the local Christian population in the anti-Jewish violence in Romania's borderlands during and beyond July 1941, as well as its significance for the study of the Holocaust in Romania. Despite the subject having been explored from different angles and to different degrees, it has yet to receive the centrality it deserves and its full extent has not yet been clearly established. ${ }^{114}$

The Holocaust in the Romanian Borderlands is not a departure from but an addition to the previous scholarly endeavors to establish the nature and scope of the Christian locals' involvement in the anti-Jewish violence in Romania's borderlands. Pioneer researchers such as Jean Ancel examined the circumstances and mindset that prompted Christian locals to victimize their Jewish neighbors and concluded that the anti-Jewish violence taking place in rural and semirural areas where no prior tensions were recorded between Jews and Christians was not entirely of a spontaneous nature. In his opinion, the Romanian and Ukrainian locals' sudden change of attitude toward Jews was informed by the military authorities' elaborate plan to incite the Christian population against the Jews. The collective hostility that emerged immediately after the Soviets' withdrawal 
was against Jews both as Jews and as perceived allies of the Soviets, the foreign invader. ${ }^{115}$ Ancel's analysis helps distinguish between the two kinds of physical violence committed against Jews during the interregnum, namely spontaneous and organized. The scholar emphasized the importance of context for the understanding of the perpetrators' modi operandi and the relevance of the ideologically connotated perception of the victims. However, Ancel did not pursue the analysis of the role civilians played in anti-Jewish policies post-July 1941. He refrained from examining how the changing situational dynamic informed the initiative of local people against the Jews following the re-annexation of northern Bukovina and Bessarabia. Ancel stopped short of addressing the important questions of whether the evolution of state-sponsored persecution generated new forms and patterns of civilian complicity.

Radu Ioanid interpreted the spread of popular antisemitic violence after July 1941 as a turning point in the development of the Romanian Holocaust. He established that among the most important factors leading to the extermination of the Jews were the antisemitic stereotypes portraying them collectively as proCommunist, the resentment against Jews as a capitalist element in a predominantly peasant-worker environment, and the opportunism of criminal and sub-criminal elements. ${ }^{116}$ Despite Ioanid's generous attention to the massacres with civilian participation during the re-annexation of the two regions and his important observations about the identity of certain non-military perpetrators, their relation to the victims as well as the physical, economic and situational variations of anti-Jewish violence, the historian did not examine in depth the evolution of the relationship between state structures and civil actors. During the de-Judaization of the borderlands, highly relevant aspects which Ioanid stressed in his work, such as the multifaceted hostility directed against the Jews and the situational factors represented by opportunistic conduct and motives, converged and propelled the persecution of the Jews even after the massive deportations of 1941-1942.

The more recent historiography on the Holocaust in Romania looked even more closely into the influence local civilians had on anti-Jewish violence in the re-annexed territories. Vladimir Solonari distinguished between the negligible assistance provided by Christian locals in the cities and the critical support they extended in the countryside. ${ }^{117}$ According to Solonari, ideology motivated Ukrainian nationalists and Romanian fascists to commit massacres in northern Bukovina and Bessarabia. A desire to secure favors from the Romanian authorities drove mayors and other members of local administrations to assist the Romanian military authorities. Corruption was another incentive for which poor and uneducated peasants who wanted to become rich offered to help the Romanian soldiers and gendarmes. ${ }^{118}$ Solonari expanded Ioanid's foundational work and pursued an even more systematic analysis of the context in which local actors engaged in the victimization of their Jewish neighbors, their background and incentives for the crimes. Despite Solonari's valuable contributions, he refrained from assessing the ramifications of the horizontal interactions between state institutions and civilians or civilian institutions during the subsequent phases of the Holocaust in the borderlands. The anti-Jewish violence with civilian participation is thus documented 
as a series of developments related to a certain stage of the war and not as a phenomenon fueled by recurrent personal initiatives stemming from the grassroots.

The German historian Armin Heinen divided the antisemitic violence in Romania after September 1940 into five categories: dictatorial, fascist, military, police and collective. He evaluated each category from eight viewpoints: the significance of traditional antisemitism, the motivation for the acts of violence, the causes, the type of violence, Germany's influence, the context in which violence occurred, the duration of the violence, and the reasons for its cessation. According to Heinen, the collective violence that occurred in June and July 1941 was not necessarily a consequence of traditional antisemitism but of anomie and the desire for self-enrichment. It emerged in the context of war psychosis, evolved independently from German influence and took the form of pogroms and plunder which were brought to a halt by the end of a period of power vacuum. ${ }^{119}$ Focusing on the crimes committed by Romanian and Ukrainian peasants in rural Bukovina and Bessarabia, Heinen contended that magical action and ritualistic removal of any Jewish presence from the space of the village was at the core of the civilian perpetrators' mindset and a central characteristic of their murderous actions. ${ }^{120}$ Heinen's assessment is instrumental for the multidimensional interpretation of anti-Jewish violence as a social, cultural and political attribute of Romanian society during the late 1930s and World War II years. Heinen's shortcoming is that he evaluated the structural factors for antisemitic violence almost entirely in relation to the popular and collective victimization of the Jews in June and July 1941. He reduced a lengthier and more complex process to its incipient phase and determined its theoretical significance in isolation from the subsequent patterns of antiJewish violence.

Simon Geissbühler's examination of the anti-Jewish violence in Bessarabia and Bukovina in early July 1941 highlighted, among other things, the significance of context. Geissbühler explained that the military perpetrators felt ideologically and politically justified in killing because the war allowed them to do so and to go unpunished. The interregnum and its vacuum of authority was used by the Christian locals in northern Bukovina and northern Bessarabia to stage their assault on Jewish life and property. ${ }^{121}$ According to Geissbühler, the pogroms in early July 1941 were committed by heterogeneous groups of perpetrators. Often the anti-Jewish actions initiated by soldiers and civilians intersected or overlapped. ${ }^{122}$ As for the reasons for which local people committed the crimes, the Swiss scholar considered it difficult to establish with precision the various driving forces. However, he found little reason to doubt the influence that ideology had on the murderers, especially a radical version of nationalism and antisemitism. The myth of Jewish treason in the summer of 1940 also structured the Romanian perpetrators' mindset, while the Ukrainian nationalists regarded Jews as beneficiaries of the Soviet regime. Lastly, the economic motives need to also be taken into account. The appeal of material gains fueled the ideological drive of the perpetrators. ${ }^{123}$ Geissbühler reinvigorated the discussion on the role of ordinary people during the Holocaust in Romania's borderlands. He consolidated the knowledge existent in secondary literature on the subject of popular violence in the Romanian context and provided a useful 
reminder that the academic discussion it entails is not yet at its most fertile stage. Geissbühler's analysis is limited in scope because of the researcher's exclusive focus on the episodes of physical violence against the Jews that engulfed the two regions during and immediately after re-annexation. This methodological option prevented Geissbühler's approach from encompassing later stages of civilian participation, shedding light on perpetrators who did not come solely from the rural or semi-rural milieu and whose ethnic backgrounds were other than Romanian and Ukrainian, the two prevalent identities during the massacres of July 1941.

Diana Dumitru interpreted the escalation of tensions between Jews and Christians in Bessarabia after July 1941 as the result of prewar precedents of discrimination and various abuses against Jews, and the permissive socio-political environment within which they took place. In her opinion, the short Soviet occupation of 1940-1941 could not have led to a drastic change of attitudes among the Christian locals. ${ }^{124}$ Dumitru concentrated on the political climate of interwar Romania in comparison to the one cultivated by the Soviet Union and established in the case of the former the centrality of the state as a superstructure responsible for the anti-Jewish emotions, views and actions of its subjects. An equally valuable contribution is the fact that Dumitru zoomed in on local realities of both urban and rural Bessarabia and examined the deterioration of interethnic relations in one of Romania's two borderland regions re-annexed from the Soviet Union, namely Bessarabia. In Dumitru's view, an unrelenting history of antisemitism predisposed Bessarabians to inform the state-sponsored anti-Jewish violence in the region. Dumitru's contribution is only in part helpful since it doesn't take into account the developments in the neighboring region of Bukovina. Dumitru's self-limitation concerning the geographical space and attitudinal spectrum covered is a missed opportunity to assess comparatively the patterns of civilian complicity in both borderland regions.

The frequency and distribution of anti-Jewish episodes with civilian assistance during the summer of 1941 cannot be the sole barometer for the nature and scope of civilian complicity during the Holocaust in Romania's borderlands. A leap toward a more comprehensive and consistent understanding of the phenomenon is possible only if more factual knowledge is added to the bulk of data on which historians have exclusively focused and relied so far. This has the potential to lead to a renewed discussion on the significance of civilian participation throughout the years in which Romania carried out its anti-Jewish policies in the two regions. My investigation transcends the thematic limitations of previous approaches and demonstrates that just as the official persecution of the Jews was a multi-phase process, so was the engagement of various civilians with it. Not only was this relationship longer and more complex than has been illustrated so far, but its nature, as the case studies included in this book suggest, was from beginning to end one of horizontal and coherent cooperation rather than top-down enforcement.

\section{Core questions and concepts}

Israel Charny wrote about bystanders that they are people who see but remain "invisible." They witness things but make themselves blind to their surroundings 
and blend into the background as if they have no identity. Their tactic is to distance themselves from the events that they observe. ${ }^{125}$ At the core of this book is not the withdrawal into invisibility of those who witnessed the Holocaust but rather the participatory demeanor of civilians in relation to the persecution and extermination of the Jews in Bessarabia and Bukovina after Romania joined the Nazi invasion of the Soviet Union in the summer of 1941. Central to my analysis are the changing patterns of civilian complicity and the short- or long-term impact they had on the different phases of the Holocaust in the two regions. I contend that the complete destruction of Jewish life in Bukovina and Bessarabia after July 1941 was not informed by vertical, top-down enforcement of policy or recourse to coercive measures but facilitated by the horizontal cooperation between the military establishment and the local society. I aim to determine whether the statesponsored eradication of the Jewish population in the two regions was fueled by individual civilians, groups, professional associations and institutions, and if these actors pursued anti-Jewish action both in collusion with and independently from the military authorities.

I will analyze the background of the local perpetrators, their context of involvement and motivation, outside existing conceptual conventions. In this sense, I will reevaluate the categories of civilians who became complicit in the persecution of the Jews as well as the forms their complicity took between the different stages of the Holocaust. ${ }^{126}$ My systematic approach to the subject will be guided by a number of foundational questions. How and why was action taken against the local Jews by their Christian neighbors before and immediately after the change of regime in Bukovina and Bessarabia? Who were the local people assisting the military authorities in the roundups and ghettoization of Bukovinian and Bessarabian Jews, and what were the reasons for their involvement? Were those civilians who assisted of the same ethnic or religious background as the main perpetrators? In what ways did Christian commoners or civilian authorities inform the persecution of the Jews from Romania's borderlands during their deportation to Transnistria or in its aftermath, and what was their agenda? Why was pressure exerted from the grassroots against Jews exempted from deportation and how did Romanians respond to the flaws in the implementation of the Romanianization of occupations and the workforce? To what extent was the professional occupation or the social status of the accomplices a determinant factor in the influence they exerted on the local developments and how much access to power and authority did they have?

In common language, the term "collaborator" denotes the action of participating in a certain task. In the wake of World War II, the notion acquired a pejorative meaning in some political contexts. The first shift in the meaning of the term occurred in the context of Marshal Petain's speech on October 30, 1940, when he affirmed: "I am today setting out along the road of collaboration." ${ }^{127}$ In its negative sense, "the collaborator" has become synonymous with an agent of a foreign or depreciated policy or ideology. In this sense, collaboration insinuates betrayal and consists of an individual or group behaving directly or indirectly as the proxy of an external power. ${ }^{128}$ 
The existing research on collaboration during the Holocaust in countries occupied by or allied with Nazi Germany offers different definitions of the phenomenon and unveils many of its facets. Various scholars have explained how social, political and historical forces, as well as more personal factors such as individual responsibility, morality and prejudice, were determinant in making ordinary members of society ready to collaborate.

In Polish Society under German Occupation: The Generalgouvernment 19391944, Jan Tomasz Gross interpreted collaboration as a phenomenon that takes place in a context where power is unevenly distributed and the occupied are willing to grant the occupiers authority without necessarily assisting by providing information or offering expertise. ${ }^{129}$ But the occupied did not have to be a territorially conquered people to concede dominance to National Socialism imposed from above. Ian Kershaw explained that all sections within German society, including certain parts of the working class which metabolized socialism, displayed signs of ideological disorientation as a consequence of sustained exposure to publicly unchallenged propaganda. The absence of public criticism directed toward governmental policy, which is the cornerstone of pluralistic opinion formation in a democratic society, was conducive to the narrowing of the masses' political horizons and the deepening of the effect that Nazi ideology had on them. ${ }^{130}$

Victoria Barnett examined the prerequisites of collaboration in Germany and concluded that Nazism exerted pressure on individual citizens through the totalitarian ideology it imposed upon them. Many Germans claimed they felt powerless. For Barnett, however, powerlessness is a complex phenomenon. She wonders whether powerlessness was a reflection of immediate realities or whether it stood for an attitude of implicit approval for what was happening and rationalization for passivity. ${ }^{131}$ In-depth interviews conducted by social scientists with both Nazis and passive witnesses confirm Barnett's assumption and indicate that these categories of people exhibited worldviews colored by fatalism which was related to their perceived lack of choice to help others. Passive self-images and an external locus for agency determined some people to accept whatever life had in store for them and were given the impression that they had no control over the plight experienced by others. ${ }^{132}$

During the Holocaust, the internalization of external situations shaped the ways in which various groups of civilians responded to mass violence. Raul Hilberg's assessment was that the Ukrainian population living in damaged cities with disrupted communications were a disoriented people, uncertain of their future under Nazi administration. Forced to do everything in their power to stay alive against a background of disintegration, Ukrainians perceived Jews as a different people whose misfortune, deserved or not, was not their concern and even less so their responsibility. ${ }^{133}$ Gabriel Finder and Alexander Prusin argued that in Ukraine, social mutations occurred through complex forms of interaction between the occupier and the occupied. Rapid social changes in occupied societies determined the readiness of social milieus sympathetic to the idea of collaboration to embrace Nazi ideology and take advantage of emerging opportunities. ${ }^{134}$ British historian Martin Dean investigated the collaboration in Belorussia and Ukraine 
and established that among the people who facilitated the implementation of the Nazi genocide in the East were nationalist activists, local hooligans, antisemites, people with a criminal record and individuals animated by personal ambitions. A separate group comprised killers who volunteered for execution assignments because it provided them with a thrill and sense of power. Most of the collaborators were initially motivated by revenge against the Soviets and the desire to secure a regular wage. Other driving forces included greed, alcoholism, careerism and peer pressure. ${ }^{135}$

Wendy Lower's seminal study on the German occupation of Ukraine during World War II exposed new dimensions of the behavior of Ukrainian civilians who assisted the Nazis. Lower examined the appointed indigenous leaders and established that almost all of them had a middle-school education and belonged to the local professional class of teachers, doctors, priests and bookkeepers. They were mainly over 40 years old and had experienced both World War I and the Bolshevik revolution. From the Germans' viewpoint, the Ukrainian district leaders and village elders were willing to assist but in an apathetic rather than enthusiastic manner. Lower also showed that while the Germans needed local help to administer the conquered territory, Ukrainians as well as ethnic Germans found their way out of the impasse created by war-induced unemployment through the pursuit of administrative jobs with the Nazi regime. ${ }^{136}$

The war also created opportunities, and opportunists, in Croatia, where the favorites of the regime were those who benefited from the system created after the country became the Independent State of Croatia in April 1941. Jewish firms were handed over first to Ustasha who arrived from abroad, then to Ustasha in Croatia, and finally to people with a reputation for Croatian nationalism. ${ }^{137}$ The social structure of the Ustasha movement that originated outside Croatia included students and intellectuals but the rank-and-file was dominated by workers, peasants and sailors. Their educational level was basic and most of the small number of students had not completed their university education. By contrast, among the activists of the Ustasha movement in Croatia there was a far higher proportion of students and intellectuals. While the latter were mainly engaged in violent protests, the former did not refrain from employing terrorist methods. ${ }^{138}$ Pursued on a massive scale by the Ustasha establishment, the looting of Jewish property is considered to have sealed the fate of numerous Croatian Jews. Many of them died soon after because those who robbed them ensured they would be deported and killed. Jewish property also attracted civilian institutions. They pressured the authorities to be allowed to benefit from the expropriation process. ${ }^{139}$

Like a reflection in the mirror, Italian civilians also sought to expedite the persecution of the country's Jewish population during the Republic of Salò (September 1943 - May 1945) in order to benefit from the victims' expropriation. Previous research has painted an incomplete picture showing only how over 80 percent of the Jews residing in Italy survived due to the solidarity of the Italian population. ${ }^{140}$ However, Simon Levis Sullam's incisive analysis of regional and local dynamics proved indisputably that both ordinary Italian citizens and various civilian figures with different functions and degrees of responsibility became complicit in the 


\section{Introduction}

genocide of the Jews. Prefects, the administrative staff of smaller towns and villages, Fascist party members and clerks, householders, truck drivers, impromptu guides at the Italian-Swiss border and grassroots denunciators assisted the German and Italian authorities in their anti-Jewish measures. Ideologically motivated perpetrators, bureaucrats driven by repressive zeal and people who were in the pursuit of profit had been absorbing the officially sanctioned antisemitism since 1938, which provided the background for the genocidal shift of 1943-1945. ${ }^{141}$

If in some countries the war paved the way for the pursuit of national revolution and the implementation of a process of national regeneration, in others it altered social realities and generated new popular attitudes. In Hungary, it was the German occupation of March 1944 which brought to an end the physical protection Jews still enjoyed despite the civil, socioeconomic and military discriminatory measures imposed upon them since 1938. ${ }^{142}$ By equating the anti-Jewish measures with the national interest of the country, the pro-Nazi authorities secured the attention of a large segment of the Christian population. While some Hungarians adhered to the objective of their Nazi allies because of ideological or patriotic reasons, others acted out of opportunism. Hitler's suggestion that those engaged in antiJewish activities be rewarded with confiscated Jewish capital was conducive to an enthusiastic response from numerous Hungarians. During the occupation, the Hungarian and German authorities received between 30,000 and 35,000 denunciations of Jews throughout the country. If some pursued active cooperation, the majority of the Christian population remained passive in the face of the persecution of the Jews, mainly because of the fear inspired by the government. ${ }^{143}$

In the Balkans, Nazi dominance and its securement of a collaborationist infrastructure became a reality soon after Yugoslavia's capitulation on April 15, 1941. Hitler created the Territory of the Military Commander in Serbia (MBS) as a structure which exercised total legislative, executive and judicial powers, and was under his direct authority. A collaborationist administration was created to compensate for the shortage of manpower, to deliver commodities that the Third Reich wanted, and to help the Germans preserve order by means of the native civil service and police. The nationalistically inclined youth were organized into Serbian Volunteer Detachments (SDK), which almost immediately engaged in combat with the Partisans. In a few months their units grew to 3,500 and were subsequently integrated into the German police structure. Another collaborationist unit in Serbia was the Special Police, which was composed of experienced and zealous professionals whose main objective was to combat Communist resistance. The German assault on the Serbian Jews followed the outbreak of the war in April 1941 and was initially pursued in a disorderly fashion. German soldiers joined the local mob in Belgrade and looted Jewish stores, houses and apartments. Vicious anti-Jewish violence occurred in the Banat region where soldiers and ethnic Germans mistreated the Jews and humiliated them publicly. Hundreds were detained in the first concentration camps while plunder continued and reached colossal proportions. When the assault on Jewish property acquired an organized character, ethnic Germans became privileged beneficiaries of the transfer of Jewish property in Banat. ${ }^{144}$ 
Internal rifts between ethnic groups were some of the abrupt social changes which affected entire populations in countries confronted with the prospect or harsh reality of Nazi occupation. Leonid Rein's analysis of the transformations in Belorussia concluded that collaboration cannot be understood outside the context of the reality of occupation. The destructive social influences of the Nazi occupation resulted in the disintegration of all existing social ties in Belorussia. Collaboration with the Germans did not necessarily mean identification with their National Socialist ideology or its goals but was rather a reaction to the occupation rule. As the occupation progressed and conditions became increasingly harsh, people gradually came to consider collaboration their only means of survival, rather than the fulfillment of their nationalist dreams. ${ }^{145}$

That ethnic resentment and extreme nationalism were not invariably responsible for the involvement of civilians in the victimization of the Jews in occupied Europe is also suggested by the scholar Tomasz Frydel. He argued that in Poland, the opposite of grassroots ethnic cleansing occurred when the peasant society participated in the capture and murder of Jews out of communal fear and their own desire to survive, not because of ethnic resentment or extreme nationalism. Frydel stresses the importance of a locally situated dynamic emerging from the reconfiguration of the structures of village authority by the occupation authorities who were determined to further pursue the elimination of the Jews. He suggested that two trajectories of experience stemmed from the German occupation and that they often prolonged into an existential competition which is paramount for the understanding of the specific dynamics of violence from the grassroots. ${ }^{146}$

While some researchers place major emphasis on situational constraints as they try to grasp the murderous behavior of local people, others attempt to refine the descriptive terminology scholars employ when referring to this category of perpetrators. A broader understanding of the role civilians play in mass violence is advanced by sociologist Eric Markusen, who defines accomplices as participants in genocidal projects who never get their hands dirty or even witness the actual killings but who still make necessary contributions. These contributions consist of articulating, rationalizing and promulgating a victimizing ideology as well as of laws, policies and practices that persecute a targeted group. Lastly, Markusen's accomplices also serve the killing project by designing, creating and servicing the technology involved in organizing and implementing the actual killing. ${ }^{147}$ Along similar lines, Simon Geissbühler differentiates between perpetrators, collaborators and accomplices based on different degrees of active and unmediated participation. In his view, those who collaborated did not have to personally and directly engage in the murder of the Jews, but they supported the main perpetrators in various ways and on different levels, out of personal interest. According to the Swiss scholar, the majority of civilians were accomplices, as they were aware of the main perpetrators and their collaborators' deeds and did not oppose them. Geissbühler ascribes an equal amount of opportunism to accomplices as he does to collaborators. ${ }^{148}$

My conceptualization of the civilian perpetrators discussed in this book is a context-sensitive one. It prioritizes the manner in which military and civilian 
actors perceived and related to each other. In July 1941, the Romanian population in Bessarabia and Bukovina received the Romanian troops with ovations. National pride and solidarity were expressed, and the Romanian flag was displayed in different localities traversed by the country's army. The locals offered produce and livestock to the troops stationed in villages. ${ }^{149}$ The Romanian forces returning to Bessarabia and northern Bukovina at the end of the year-long Soviet occupation were not perceived by the Romanian population as invaders but as liberators, with whom they were united in a common national cause. ${ }^{150}$ In one of the episodes I will examine, the Ukrainian nationalists in northern Bukovina regarded the Germans as their allies in the fight for an independent state in the region.

The nature of the relationship between the civilian population and the military authorities in the two regions, and how the latter were perceived by the former, justifies the need for alternative notions to describe the locals' involvement in anti-Jewish actions. Unlike the notions of collaborator and collaboration the terms accomplice and complicity do not have a dual connotation and are a legitimate alternative to describe the participatory behavior of civilians in anti-Jewish violence outside the context of occupation. As common law concepts, their sole meaning is in relation to the commission of a crime, where the accomplice is abetting the perpetration of the criminal act.

For the purpose of my research I regarded as a civilian accomplice any inhabitant of a village, town or city in Bessarabia and Bukovina, of any national, religious or professional background, who was physically present in the two territories during and after July 1941, and who voluntarily or not, because of one or more reasons, participated in the persecution and extermination of Jews initiated by the military authorities from that date onward. Included in the category of civilian accomplice is any person other than the Romanian soldiers, gendarmes and policemen who contributed to the perpetration of physical violence against the Jews by informing the authorities about Jews in hiding, joining in the search for Jews, identifying local Jews as Communist suspects and facilitating their apprehension, rounding up and torturing Jews, observing orders to kill Jews or initiating the murder of Jews themselves. Equally relevant for my study were those instances in which Christian locals engaged in discursive violence against the Jews by petitioning the authorities, submitting collective complaints against Jews, or denouncing them.

Reconstructing the profile of the civilian accomplice depends not only on establishing the culprits' personal background and the immediate context that made possible their involvement. Identifying, distinguishing and explaining the driving forces behind the civilian perpetrators' actions represents one of the goals of my research but also an objective challenge. ${ }^{151}$ Understanding how and why in so many cases Christian neighbors turned into active facilitators of the statesponsored violence against the Jews is an integral part of my overall efforts to document and elucidate this phenomenon in its entire complexity.

I contend that both emotional-ideological and pragmatic reasons animated the civilian accomplices in Bessarabia and Bukovina. I consider antisemitism and anti-Communism to have not only ideological grounds but also emotional 
implications. On the other hand, I classify greed and opportunism as pragmatic in nature. Numerous episodes of anti-Jewish violence from the case studies covered by my research can be used to exemplify the prevalence of these two categories of motives either separately or together. More often than not, they informed the accomplices' attitude and actions simultaneously.

What did antisemitism and anti-Communism actually signify in the Romanian context? After June 1940, when Romania lost Bessarabia and Bukovina to the Soviet Union, antisemitism and anti-Communism often overlapped, in the sense that Jews were targeted both as Jews and as Communists. According to Radu Ioanid, Romanian nationalism exploited antisemitic stereotypes to depict the Jewish community in its entirety as a pro-Bolshevik fifth column. ${ }^{152}$ In Vladimir Solonari's view, the locals who volunteered to assist with the repressive measures against the Jews strongly believed that they were acting against the nation's enemies, who they blamed for the suffering triggered by the Soviet occupation. ${ }^{153}$ Mariana Hausleitner showed that the stereotype of Jewish-Communist gangs was widespread in northeast Romania in the summer of 1940. The stereotype became more relevant once the propaganda started presenting the loss of the two borderland regions as the wish of the Jews. ${ }^{154}$ Simon Geissbühler argued that the influential myth of "Jewish treachery" following Romania's loss of the two borderland regions to the Soviet Union had as an effect the intensification of antisemitism. ${ }^{155}$

As for the role played by greed, a legitimate question is whether it was a cause or a consequence of anti-Jewish violence. I regard the presence of greed within the mindset of civilian perpetrators as a premise for their involvement rather than a consequence of the violence in which they engaged. Despite poverty being a socio-economic reality among Jews as well, many Christians perceived them as invariably wealthy. In Ioanid's opinion, at the beginning of the war, the resentment against Jews as a capitalist element in a preeminently peasant-worker environment became more visible. The fascist propaganda did not hesitate to capitalize on these feelings. ${ }^{156}$ Hausleitner explained the disenfranchisement of the Jews in Romania as a result of the high percentage in which they were represented in economic and social positions. ${ }^{157}$ Diana Dumitru argued that for the Bessarabian peasants the plunder of Jewish assets represented a "natural" way to even out what was perceived as an unjust economic and social state of affairs that had lasted for too long. ${ }^{158}$

Nevertheless, it is not inconceivable that in some cases economic interests in the victims' assets became part of the local people's mindset after the victims were murdered. Geissbühler lists economic reasons as playing a central role in the anti-Jewish violence in Bessarabia and Bukovina and asserts that Christian locals had no qualms about appropriating the land, houses or personal items of the murdered or deported Jews. ${ }^{159}$ Opportunism was not only economic in nature. Professional opportunism developed in parallel with the pursuit of material gains. One of its forms was careerism. In some cases, ordinary Bessarabians and Bukovinians sought to prove their loyalty to the new regime or to secure a better status or other favors from the authorities. ${ }^{160}$ 


\section{Primary sources}

Elucidating the nature and scope of the crimes committed by civilians in Bessarabia and Bukovina is a task that can be best achieved by corroborating the intelligence obtained from various sources. Integrating survivor testimonies, witness accounts and perpetrator viewpoints is the methodological cornerstone of my research project. The evidence I will present and analyze in this book was generated during extensive archival research and comes from war crimes trials, oral history testimonies, official correspondence exchanged between private petitioners or denouncers and the official authorities, and survivor memoirs.

At the United States Holocaust Memorial Museum in Washington D.C., I evaluated a significant number of collections. One of them was the Selected Records from the Romanian Information Service, 1936-1948 (RG-25.004M), which contains documents about the massacres and pogroms carried out in Romania as well as the war crimes investigations and war crimes trials of the Antonescu regime. Another collection was the Archives of the Romanian Ministry of Defense (RG-25.003M), created by various Romanian army units during World War II, which contains correspondence, orders, reports and other documents concerning the deportation of Jews from Bessarabia and Bukovina to Transnistria. Equally important was the Selected Records from the Moldova National Archives (RG-54.001M), encompassing materials on the interment of Jews in camps and ghettos, the forced labor of Jews in Chișinău, the orders and instructions for their deportation and the killings of Jews throughout Bessarabia. The Selected Records of the Liaison Office for Bessarabia, Bukovina and Transnistria (RG-54.004M) was relevant because of its archival documents related to the implementation of population policies in various Romanian provinces and the Romanianization of Jewish properties and assets. The Czernowitz Oblast Archives Records (RG-31.006M) included various materials pertaining to the ghettoization and other forms of persecution against Jews in Cernăuți, as well as denunciations against Jews and Communist suspects. Also relevant for my research was the Odessa Oblast Archives (RG-31.004M) because of its police documents concerning the Communist organizations and Iron Guard, in a number of towns in southern Bessarabia. I examined the collection titled Selected Records of the Romanian Ministry of Work, Health and Social Protection - Central Office of Romanianization (Aryanization) 1939-1944 (RG-25.024M) due to its substantial content of documents on denunciations of Jews by Romanian ethnics, the requests by refugees and other Romanian ethnics to be "placed" in various jobs and the inspection of individual companies and private individuals concerning Romanianization.

The collection of documents War Crimes Investigation and Trial Records from the Republic of Moldova (1944-1955) (RG-54.003) was relevant for its documents related to the criminal investigations into war crimes and enemy collaboration in Moldova and Transnistria conducted by the Soviet authorities. Despite the original language of the documents being Russian, I was able to access the content of this collection because numerous files contain ample summaries of postwar trials in Romanian. 
A different category of sources I utilized in my research was the witness testimonies collected by the United States Holocaust Memorial Museum and included in the Oral History archives entitled Moldova Documentation Project and Romania Documentation Project. The survivor testimonies made available by the University of Southern California Shoah Foundation Institute, Visual History Archives, were no less significant and also became part of the materials gathered during my archival research.

The alleged bias of the perpetrators, victims or witnesses at the origin of my sources required that I approach them critically. In an effort to compensate for the inherent limitations concerning their reliability and to minimize any interpretive challenges I triangulated the archival materials, oral testimonies and scholarly explanations.

I sought to independently corroborate the evidence generated by my research in an attempt to avoid articulating a one-sided narrative. In this sense, I included in my analysis case studies and examples that are supported by multiple sources. I examined divergent accounts comparatively and attempted to establish their validity or relevance in relation to the totality of evidence amassed. I treated with a degree of caution the findings of my research that pertained to the background, context of involvement and motives of the civilian accomplices.

Despite the instrumental value of the sources I used in my research to document and analyze the participation of civilians in antisemitic violence, their nature is such that they might lead to a disproportionate sense as to the scale of the participation of Christian civilians in the persecution of the Jews in the two regions. To counterbalance this effect, the book will explore the attitude and actions of various non-Jewish rescuers to a limited extent in a separate subsection.

\section{Chapter prospect}

This study's findings illustrate the impact of the cooperation between the local population and the military authorities on the state-sponsored persecution of the Jews. The actions of Christian locals were murderous as well as undermining or destructive in non-physical ways. People from different walks of life became involved from the very beginning of the re-annexation until long after the deportations had concluded.

In the aftermath of the Soviet withdrawal from northern Bukovina and Bessarabia, numerous villages and towns witnessed the rapid deterioration of inter-ethnic relations which spawned violent attacks on Jews by their Christian neighbors. The first chapter, "The beginning of the end: mass murder and physical violence," will synthesize the intelligence made available by a cluster of episodes that took place during the interregnum, highlight the role of civilian participation in the official persecution of the Jews, and draw conclusions about the forces that drove local people to commit the abuses. What role did hatred and ideology, economic envy and greed, or opportunism and the eagerness to secure favors with the Romanian authorities play in turning local people against their Jewish neighbors? In northern Bukovina the civilian perpetrators were Ukrainian nationalists whose murderous 
actions should be understood in the context of a regional struggle to create an ethnically pure state, while in Herța they were Romanian fascists who welcomed the opportunity to assist the Romanian authorities. In Bessarabia, Romanian villagers organized massacres of entire Jewish communities as well as assisted in the apprehension and execution of Jews by the Romanian army, gendarmerie and police.

As the persecution of the Jews in Romania's borderlands continued with their ghettoization, internment in camps and deportation to Transnistria, the cooperation between the local population and the military authorities moved on to a new phase. The abrupt physical violence from before decreased in frequency and intensity. As the authorities were proceeding with a more organized stage in the persecution of the Jews, the patterns of complicity and the roles assumed by the accomplices acquired new dimensions. In the second chapter, "Civilian complicity during camp internment, ghettoization and deportation," I will determine if and how the pattern of civilian involvement in anti-Jewish violence has transformed over time. Did the accomplices' background change, and if so, in what ways? How can we make sense of the participation in persecution by ordinary citizens, acquainted with the deportees, who sought to profit from their removal, and also by various categories of professionals such as bank envoys, hospital administrators, physicians and legal practitioners? Were the motives for their behavior the same or different? Do the research findings examined in this chapter add a new layer to the overall discussion on the motivational complexity of the civilian participants, or confirm previously encountered patterns?

Once the majority of the Bukovinian and Bessarabian Jews had been deported, those retained for economic reasons faced collective complaints and recurrent acts of denunciation by a number of Christian locals. Non-Jewish civilians who took over Jewish properties turned in to the authorities those Jewish escapees from Transnistria who had returned to their homes. The emergence of a considerable number of cases in which local civilians informed on Jews suggests that a denunciatory atmosphere developed in Romania's borderlands following the change of regime. My third chapter, "Pressure from below: petitioning, collective complaint and denunciation," will trace the evolution of civilian complicity and its impact on the persecution of Jews in Bukovina and Bessarabia during this advanced phase of the Holocaust. I will try to establish whether the categories of local people involved in the anti-Jewish persecution, and their reasons for becoming involved, were different from the previous stages. Did civilians seek to become more stringent enforcers of anti-Jewish legislation than the local or regional authorities during this phase of the Holocaust? Was the Christian locals' determination to radicalize the decision-making process on a local and regional level indicative of a change of pattern in the dynamic of civilian complicity post-deportation?

This section will also integrate evidence about the role played by local Christians in the Romanianization process. I will assert that a major impetus for the spoliation of Jewish property by the state and the elimination of the Jewish workforce in Bessarabia and Bukovina was the actions taken by numerous civilians on a local level. What distinguishes this chapter is that it argues for a different understanding of the ways in which the persecution of the Jews was fueled by 
civilian action. At this stage, it was through the exertion of social pressure rather than the perpetration of mass murder that Christian locals enhanced the dynamics of exclusion and economic marginalization set in motion by the military leadership of the country. 


\section{Notes}

\section{Introduction}

1 Paul Valéry is quoted by Jacques Semelin. See Jacques Semelin, Purify and Destroy: The Political Uses of Massacre and Genocide (New York: Columbia University Press, 2007), 22-23.

2 Benedict Anderson, Imagined Communities: Reflections on the Origin and Spread of Nationalism (London and New York: Verso, 2006), 4.

3 William Oldson, A Providential Anti-Semitism. Nationalism and Polity in Nineteenth Century Romania (Philadelphia: The American Philosophical Society, 1991), $154-155$.

4 United States Holocaust Memorial Museum, RG-25.003M Selected Records from the Romanian Ministry of Defense 1940-1945, File 32, Reel 131, 65.

5 Radu Ioanid, The Holocaust in Romania: The Destruction of Jews and Gypsies Under the Antonescu Regime, 1940-1944 (Chicago: Ivan R Dee, 2000), 290.

6 Jewish survivors described the outburst of collective nationalist hatred and individual sadism as well as the pogroms and massacres perpetrated by the Romanian army and gendarmerie as harsher than those committed by the Germans. See Wolfgang Benz, "România şi holocaustul" in Wolfgang Benz and Brigitte Mihok (eds.), Holocaustul la Periferie: Persecutarea și nimicirea evreilor în România și Transnistria în 19401944 (Chișinău: Cartier, 2010), 27.

7 Viorel Achim, "Deportarea evreilor în Transnistria în contextual politicii demografice a guvernului Antonescu" in Wolfgang Benz and Brigitte Mihok (eds.), Holocaustul la Periferie: Persecutarea și nimicirea evreilor în România și Transnistria în 1940-1944 (Chișinău: Cartier, 2010), 241.

8 The need for a systematic and comprehensive examination of the subject was also stressed by one of the most recent scholarly contributors. See Simon Geissbühler, “"He Spoke Yiddish Like a Jew': Neighbors' Contribution to the Mass Killing of Jews in Northern Bukovina and Bessarabia, July 1941" in Holocaust and Genocide Studies Vol. 28, No. 3 (Winter 2014), 431-432.

9 Radu Ioanid, The Sword of the Archangel: Fascist Ideology in Romania (Boulder, CO: East European Monographs, 1990), 117.

10 Andrei Pippidi, "The Mirror and Behind It: The Image of the Jew in the Romanian Society" in Shvut: Jewish Problems in Eastern Europe Vol.16, 1993, 80.

11 Jean Ancel, "The Image of the Jew in the View of the Romanian Anti-Semitic Movements: Continuity and Change" in Shvut: Jewish Problems in Eastern Europe Vol.16, 1993, 41.

12 Andrei Oișteanu, Inventing the Jew: Antisemitic Stereotypes in Romanian and Other Central-East European Cultures (Lincoln, NE and London: University of Nebraska Press, 2009), 4-6. 
13 Alan Dundes, From Game to War, and Other Psychoanalytic Essays on Folklore (Lexington, KY: University Press of Kentucky, 1997), 114.

14 Cited by Leon Volovici. See Leon Volovici, National Ideology and Antisemitism: The Case of Romanian Intellectuals in the 1930s (New York: Pergamon Press, 1991), 16.

15 Ioanid, The Sword of the Archangel, 116-117.

16 Ibid., 118.

17 William Brustein and Amy Ronnkvist, "The Roots of Anti-Semitism: Romania before The Holocaust" in Journal of Genocide Research Vol. 4, No. 2 (June 2002), 219-220.

18 Ezra Mendelsohn, The Jews of East Central Europe between the world wars (Bloomington, IN: Indiana University Press, 1983), 173-174.

19 Brustein and Ronnkvist, "The Roots of Anti-Semitism," 219.

20 Zigu Ornea, Anii treizeci: Extrema dreaptă românească (Bucharest: Cartea Românească, 2015), 311.

21 Ioanid, The Sword of the Archangel, 119.

22 Oldson, A Providential Anti-Semitism, 156.

23 Irina Livezeanu, Cultural Politics in Greater Romania: Regionalism, Nation Building and Ethnic Struggle, 1918-1930 (Ithaca, NY and London: Cornell University Press, 1995), 203.

24 Ornea, Anii treizeci, 313.

25 Maria Someșan, "Mișcarea Studențească din 1922" in Anuarul Institutului Român de Istorie Recentă, 1 (2002), 192.

26 Ornea, Anii treizeci, 313.

27 Idem.

28 Roland Clark, Holy Legionary Youth: Fascist Activism in Interwar Romania (Ithaca, NY and London: Cornell University Press, 2015), 28-29.

29 Livezeanu, Cultural Politics in Greater Romania, 245-246.

30 Volovici, National Ideology and Antisemitism, 24-27.

31 Clark, Holy Legionary Youth, 35.

32 Volovici, National Ideology and Antisemitism, 61-62.

33 Ioanid, The Sword of the Archangel, 77-78.

34 Clark, Holy Legionary Youth, 122-124.

35 Volovici, National Ideology and Antisemitism, 72-73.

36 Ioanid, The Sword of the Archangel, 80.

37 Jean Ancel (ed.) Wilhelm Filderman: Memoirs and Diaries Vol. 1, 1900-1940 (Jerusalem: Tel Aviv University and Yad Vashem, 2004), 463.

38 Brustein and Ronnkvist, "The Roots of Anti-Semitism," 219-220.

39 Ancel (ed.), Wilhelm Filderman, 463; Nationalist scientists such as Sabin Manuilă and Dimitrie Gusti ensured that minorities would be excluded from the understanding of what defined "the nation" by stressing the centrality of a biological element ("blood"). See Vladimir Solonari, Purifying the Nation: Population Exchange and Ethnic Cleansing in Nazi-Allied Romania, (Washington, DC and Baltimore, MD: Woodrow Wilson Center Press and Johns Hopkins University Press, 2010), 87.

40 Paul A. Shapiro, "Prelude to Dictatorship in Romania: The National Christian Party in Power December 1937 - February 1938" in Canadian-American Slavic Studies, VIII, 1 (Spring 1974), 55-65; According to Paul Shapiro, who uses statistical data provided by C. Enescu in Sociologie Românească, the PNC and Iron Guard support was geographically complimentary and not overlapping. In the borderlands, the Iron Guard won 22.8 percent of the votes in Bukovina and 5.0 percent in Bessarabia while the PNC received 21.3 percent in Bessarabia and 9.3 percent in Bukovina. See C. Enescu "Semnificația Alegerilor din Decemvrie 1937 în evoluția politică a neamului românesc" in Sociologie Românească II, 11-12 (November-December 1937), 512-526.

41 Ornea, Anii treizeci, 62.

42 Ioanid, The Holocaust in Romania, 18. 
43 Dalia Ofer, "Emigration and Immigration: The Changing Role of Romanian Jewry" in Randolph L. Braham (ed.), The Destruction of Romanian and Ukrainian Jews During the Antonescu Era (Boulder, CO: Social Science Monographs, 1997), 25-26.

44 Rebecca Ann Haynes, "Reluctant Allies? Iuliu Maniu and Corneliu Zelea Codreanu against King Carol II of Romania" in The Slavonic and East European Review Vol. 85, No. 1 (January 2007), 122-125.

45 Clark, Holy Legionary Youth, 218-220.

46 Haynes, "Reluctant Allies?," 127.

47 Rebecca Ann Haynes, "Germany and the Establishment of the Romanian National Legionary State, September 1940" in The Slavonic and East European Review Vol. 77, No. 4 (October 1999), 704-707.

48 Ibid., 703-709.

49 Ioanid, The Sword of the Archangel, 178.

50 Ioanid, The Holocaust in Romania, 19-22.

51 Haynes, "Germany and the Establishment of the Romanian National Legionary State," 702-707.

52 Solonari, Purifying the Nation, 95-109.

53 Haynes, "Germany and the Establishment of the Romanian National Legionary State," 709-712.

54 Clark, Holy Legionary Youth, 222-223.

55 Ioanid, The Sword of the Archangel, 180.

56 Ofer, "Emigration and Immigration," 26-27.

57 Haynes, "Germany and the Establishment of the Romanian National Legionary State," 719-720.

58 Clark, Holy Legionary Youth, 223-227.

59 Jean Ancel, The History of the Holocaust in Romania (Lincoln, NE and Jerusalem: University of Nebraska Press and Yad Vashem, 2011), 96-100.

60 Ibid., 228-229.

61 Idem, 229-232.

62 Ioanid, The Sword of the Archangel, 181-182.

63 Dennis Deletant, Hitler's Forgotten Ally. Ion Antonescu and His Regime, Romania 1940-1944 (London and New York: Palgrave Macmillan, 2006), 66.

64 Ibid., 69-72.

65 Ancel, The History of the Holocaust, 177.

66 Ibid., 183-194.

67 Ofer, "Emigration and Immigration," 29-30.

68 Deletant, Hitler's Forgotten Ally, 76-78.

69 Ancel, The History of the Holocaust, 204.

70 Deletant, Hitler's Forgotten Ally, 81.

71 Lucrețiu Pătrăşcanu is cited by Radu Ioanid. See Ioanid, The Sword of the Archangel, 194.

72 Ancel, The History of the Holocaust, 213-215.

73 Lucrețiu Pătrășcanu is cited by Radu Ioanid. See Ioanid, The Sword of the Archangel, 214.

74 Ioanid, The Holocaust in Romania, 38-42.

75 Henry Eaton, The Origins and Onset of the Romanian Holocaust (Detroit, MI: Wayne State University Press, 2013), 74-75.

76 Ibid., 77-79.

77 Idem, 81-94.

78 Idem, 95-109.

79 Solonari, Purifying the Nation, 166-167.

80 Ioanid, The Holocaust in Romania, 91.

81 Ancel, The History of the Holocaust, 218.

82 Ibid., 603. 
83 Tuvia Friling, Radu Ioanid, Mihail E. Ionescu (eds.), Final Report of the International Commission on the Holocaust in Romania (Iași: Polirom, 2005), 134.

84 Ibid., 219-220.

85 Deletant, Hitler's Forgotten Ally, 83-85.

86 Friling, Ioanid, Ionescu (eds.), Final Report, 128.

87 Ancel, The History of the Holocaust, 221.

88 Ibid., 219.

89 Ioanid, The Sword of the Archangel, 214.

90 Solonari, Purifying the Nation, 96-101.

91 Ancel, The History of the Holocaust, 223.

92 Friling, Ioanid, Ionescu (eds.), Final Report, 135-137.

93 Ancel, The History of the Holocaust, 315-317.

94 Ibid., 353-355.

95 Ibid., 355-356.

96 Friling, Ioanid, Ionescu (eds.), Final Report, 141.

97 Ancel, The History of the Holocaust, 242.

98 Ibid., 243.

99 Ioanid, The Holocaust in Romania, 142.

100 Ancel, The History of the Holocaust, 244.

101 Friling, Ioanid, Ionescu (eds.), Final Report, 142.

102 Deletant, Hitler's Forgotten Ally, 179-181.

103 Friling, Ioanid, Ionescu (eds.), Final Report, 143.

104 Ancel, The History of the Holocaust, 410-415.

105 Deletant, Hitler's Forgotten Ally, 196-197.

106 Friling, Ioanid, Ionescu (eds.), Final Report, 143.

107 Ibid., 168-172.

108 I paraphrase Jon Elster, who used the expression "opportunity for opportunism" in "Redemption for Wrongdoing. The Fate of Collaborators after 1945" in Journal of Conflict Resolution Vol. 50, No. 3 (June 2006), 328.

109 Friling, Ioanid, Ionescu (eds.), Final Report, 219-220.

110 Ibid., 381-382.

111 Ibid., 223-236.

112 Deletant, Hitler's Forgotten Ally, 73.

113 Ibid., 242-255.

114 Jean Ancel, Radu Ioanid, Vladimir Solonari, Simon Geissbühler and Diana Dumitru are among the scholars who devoted entire chapters and studies to the episodes of popular and state-sponsored violence in July 1941 and tried to systematically disentangle the factors involved. See Jean Ancel (ed.), Documents Concerning the Fate of the Romanian Jewry during the Holocaust Vol. 5 Bessarabia, Bukovina, Transnistria: extermination and survival (New York: Beate Klarsfeld Foundation, 1986); Ancel, The History of the Holocaust in Romania, 219-232; Radu Ioanid, The Holocaust in Romania: The Destruction of Jews and Gypsies Under the Antonescu Regime, 19401944 (Chicago: Ivan R Dee, 2000), 62-109; Vladimir Solonari, "'Model Province': Explaining the Holocaust of Bessarabian and Bukovinian Jewry" in Nationalities Papers Vol. 34, No. 4, (September 2006), 471-500; Solonari, Purifying the Nation: Population Exchange and Ethnic Cleansing in Nazi-Allied Romania, 168-199; Simon Geissbühler, Iulie Insângerat. România și Holocaustul din vara lui 1941 (Bucharest: Curtea Veche, 2015); Geissbühler, “'He Spoke Yiddish Like a Jew': Neighbors' Contribution to the Mass Killing of Jews in Northern Bukovina and Bessarabia, July 1941" in Holocaust and Genocide Studies Vol. 28, No. 3 (Winter 2014), 430-449; Diana Dumitru, "Through the Eyes of the Survivors: Jewish-Gentile Relations in Bessarabia and Transnistria during the Holocaust" in Anton Weiss-Wendt (ed.), Eradicating Differences: The Treatment of Minorities in Nazi-Dominated Europe, (Newcastle upon Tyne: Cambridge Scholars, 2010), 203-227; Diana Dumitru, The 
State, Antisemitism and Collaboration in the Holocaust: The Borderlands of Romania and the Soviet Union (New York: Cambridge University Press, 2016), 139-165.

115 Ancel, The History of the Holocaust, 220-221.

116 Ioanid, The Holocaust in Romania, 37.

117 In the urban areas, troops were stationed in large numbers and could easily be deployed to round up, detain and kill Jews; in the countryside, small teams of gendarmes were sent to villages to escort Jews on long distance journeys to execution sites and then murder them. See Solonari, Purifying the Nation, 192-193.

118 Ibid., 196-198.

119 Armin Heinen, România, Holocaustul și Logica Violenței (Iași: Editura Universității “Alexandru Ioan Cuza," 2011), 206-207.

120 Ibid., 195.

121 Geissbühler, Iulie Însângerat, 115-116.

122 Ibid., 119-120.

123 Ibid., 122-128.

124 Dumitru, The State, Antisemitism and Collaboration, 9.

125 Israel W. Charny, The Genocide Contagion: How We Commit and Confront Holocaust and Genocide (Lanham, MD, Boulder, CO, New York and London: Rowman \& Littlefield, 2016), 87.

126 According to Jean Ancel, the destruction of the Jews in northern Romania occurred in two stages: the spontaneous one and the planned one. See Ancel, The History of the Holocaust, 220.

127 Philippe Burrin, France under the Germans. Collaboration and Compromise (New York: The New Press, 1997), 3-4.

128 Bertram M. Gordon, "The morphology of the collaborator: the French case" in Journal of European Studies Vol. 23, No. 1 (March 1993), 2.

129 Jan Tomasz Gross, Polish Society under German Occupation: The Generalgouvernment, 1939-1944 (Princeton, NJ: Princeton University Press, 1979), 117-119.

130 Ian Kershaw, Hitler, the Germans and the Final Solution (New Haven, CT and London: Yale University Press, 2008), 123-124.

131 Victoria Barnett, Bystanders. Conscience and Complicity During the Holocaust (Westport \& London: Praeger, 1999), 18-19.

132 Kristen Renwick Monroe, "Cracking the Code of Genocide: The Moral Psychology of Rescuers, Bystanders and Nazis during the Holocaust" in Political Psychology Vol. 29, No. 5 (2008), 700.

133 Raul Hilberg, Perpetrators, Victims, Bystanders: The Jewish Catastrophe 1933-1945 (New York: HarperCollins, 1992), 200.

134 Gabriel Finder and Alexander Prusin, "Collaboration in Eastern Galicia: The Ukrainian Police and the Holocaust" in Eastern European Jewish Affairs Vol. 34, No. 2 (2004), 97.

135 Martin Dean, Collaboration in the Holocaust: Crimes of the Local Police in Belorussia and Ukraine, 1941-1944 (New York: St. Martin's Press, 2000), 162-163.

136 Wendy Lower, Nazi Empire-building and the Holocaust in Ukraine (Chapel Hill, NC: The University of North Carolina Press, 2005), 50-51.

137 Ivo and Slavko Goldstein, The Holocaust in Croatia (Pittsburgh: University of Pittsburgh Press, 2016), 168-169.

138 Rory Yeomans, Visions of Annihilation: The Ustasha Regime and the Cultural Politics of Fascism 1941-1945 (Pittsburgh: University of Pittsburgh Press, 2013), 7-8; Ivo and Slavko Goldstein also stressed that in the majority of cases, the perpetrators of cruelty and brutality came from the several hundred Ustasha returnees from emigration whose imprisonment in Italy engendered extreme hatred and dreams or revenge. See Goldstein, The Holocaust in Croatia, 516.

139 Goldstein, The Holocaust in Croatia, 177-181.

140 See Peter Longerich, Holocaust: The Nazi Persecution and Murder of the Jews (New York: Oxford University Press, 2010), 402. 
141 Simon Levis Sullam, The Italian Executioners: The Genocide of the Jews of Italy (Princeton, NJ: Princeton University Press, 2018).

142 Randolph L. Braham, The Politics of Genocide: The Holocaust in Hungary (Detroit: Wayne State University Press, 2000), 198.

143 Ibid., 220.

144 Alexander Prusin, Serbia under the Swastika: A World War II Occupation (Urbana, IL, Chicago and Springfield, IL: University of Illinois Press, 2017), 27-36, 53-58, 101-102, 135-137.

145 Leonid Rein, The Kings and the Pawns. Collaboration in Byelorussia during World War II (New York: Berghahn, 2011), 6, 17.

146 Tomasz Frydel, "Judenjagd: Reassessing the role of ordinary Poles as perpetrators in the Holocaust" in Timothy Williams and Susanne Buckley-Zistel (eds.), Perpetrators and Perpetration of Mass Violence, Action, Motivations and Dynamics (New York: Routledge, 2018), 188.

147 See Eric Markusen, "Mechanisms of Genocide" in Carol Rittner, John K. Roth and James M. Smith (eds.), Will Genocide Ever End? (St. Paul, MN: Paragon House, 2002), 86 .

148 Geissbühler, Iulie Însângerat,137-145.

149 The accounts were provided in the report of the General Staff B2 Cavalry Corps to the Second Section of the Third Army, whose subjectivity in interpreting and reporting the various states of affairs should not be ignored. The same document also described the Ukrainian population as content to have been liberated from the oppressive Soviet regime, but urged caution given the lack of sympathy this Slavic minority is known to have had in the recent past toward the Romanian cause (USHMM, RG25003M Selected Records from the Romanian Ministry of Defense 1940-1955, Reel 18, File 435, 53).

150 Vladimir Solonari has convincingly argued that Romanians regarded the reintegration of the two borderland regions, of which they were abusively deprived by the Soviets, as legitimate. They considered the Romanian-speaking population (excluding the Slavic minorities and the Roma) as members of the Romanian nation whose protection and preservation were their responsibility. The feelings were mutual, with at least part of the population in the borderlands reciprocating that view. Returning Romanian forces were more acquainted with the local realities and could rely on more social support than the Nazis did. See Solonari, "Patterns of Violence: The Local Population and the Mass Murder of Jews in Bessarabia and Northern Bukovina. July-August 1941" in Kritika: Explorations in Russian and Eurasian History, Volume 8, number 4, 2007, 752.

151 Scholars have underlined the difficulty of determining why the perpetrators acted as they did and the degree of freedom they had to do so. The constraints consist of the scarcity of primary sources that illuminate this issue and the fact that in most cases grassroots perpetrators refrained from justifying their demeanor and elaborating on their motivations. See Geissbühler, "'He Spoke Yiddish Like a Jew'," 438.

152 Ioanid, The Holocaust in Romania, 37.

153 Solonari, Purifying the Nation, 196-197.

154 Mariana Hausleitner, "Jewish Communist Gangs in Czernowitz?" in Simon Geissbühler (ed.) Romania and the Holocaust (Stuttgart: Ibidem, 2016), 17-19.

155 Geissbühler, “'He Spoke Yiddish Like a Jew',” 439.

156 Ioanid, The Holocaust in Romania, 37.

157 Hausleitner, "Jewish Communist Gangs in Czernowitz?," 19.

158 Diana Dumitru, "Peasants' Perceptions of Jewish Life in Interwar Bessarabia and how this became Interwoven into the Holocaust" in Plural Vol. I, No.1-2, (2013), 131.

159 Geissbühler, “'He Spoke Yiddish Like a Jew', 439.

160 Solonari describes how upon their arrival in a particular village, the Romanian authorities appointed a mayor and sometimes his assistants. The authorities expected 
them to participate in the disposal of the bodies after an execution had taken place. In July 1941, those locals who were chosen and invested with authority were determined to show their willingness to serve the new regime. Murdering Jews was regarded as a test of loyalty. See Solonari, Purifying the Nation, 198; Similarly, in his analysis of the massacres at the beginning of the war, Radu Ioanid highlights the role played by local mayors and their assistants in anti-Jewish measures, in different villages and towns belonging to the two regions. See Ioanid, The Holocaust in Romania, 97-98.

\section{Chapter 1}

1 According to Diana Dumitru it remains a dilemma whether the massacres in July 1941 were incited by Romanian provocateurs or were spontaneous. See Diana Dumitru, "Attitudes towards Jews in Odessa: From Soviet Rule Through Romanian Occupation 1921-1944" in Cahiers du Monde Russe 52, No. 1 (2011), 150; Simon Geissbühler opposed the dichotomy and argued that numerous massacres were spontaneous, which doesn't exclude the possibility of them being incited by external actors. See Simon Geissbühler “"He Spoke Yiddish Like a Jew”: Neighbors Contribution to the Mass Killing of Jews in Northern Bukovina and Bessarabia, July 1941" in Holocaust and Genocide Studies Vol. 28, No. 3, (Winter 2014), 441.

2 Manfred Reifer, "Istoria Evreilor din Bucovina după Ocupația Austriacă" in Evreii din România în Texte Istoriografice, ed. Lya Benjamin (Bucharest: Hasefer, 2002), $546-547$.

3 Irina Livezeanu. Cultural Politics in Greater Romania: Regionalism, Nation Building and Ethnic Struggle, 1918-1930 (Ithaca, NY and London: Cornell University Press, 1995), 55.

4 Ibid., 52-55.

5 Ibid., 56-59.

6 Manfred Reifer, "History of the Jews in the Bukowina (1919-1944)" in Geschichte der Juden in der Bukowina (History of the Jews in the Bukowina) Vol. II, ed. Hugo Gold (Tel Aviv: Olamenu, 1962), 2.

7 Livezeanu, Cutural Politics in Greater Romania, 89-90.

8 Ibid., 93-95.

9 Ibid., 98-100.

10 Jean Ancel, The History of the Holocaust in Romania (Lincoln, NE and Jerusalem: University of Nebraska Press and Yad Vashem, 2011), 6.

11 Diana Dumitru, State, Antisemitism and Collaboration in the Holocaust: The Borderlands of Romania and the Soviet Union (New York: Cambridge University Press, 2016), 58.

12 Dmitry Tartakovsky, Parallel Ruptures: Jews of Bessarabia and Transnistria Between Romanian Nationalism and Soviet Communism, 1918-1940 (Proquest, Umi Dissertation Publishing, 2011), 24.

13 Idem.

14 Dumitru, State, Antisemitism and Collaboration, 59.

15 Tartakovsky, "Parallel Ruptures," 59-63.

16 Vladimir Solonari, Purifying the Nation: Population Exchange and Ethnic Cleansing in Nazi-Allied Romania, (Washington, DC and Baltimore, MD: Woodrow Wilson Center Press and Johns Hopkins University Press, 2010), 197.

17 Lya Benjamin (ed.) Comisia Internațională pentru Studierea Holocaustului în România, Documente (Iași: Polirom, 2005); See also Tuvia Friling, Radu Ioanid, Mihail E. Ionescu (eds.), Final Report of the International Commission on the Holocaust in Romania, (Iași: Polirom, 2005), 95-107. 
18 Armin Heinen described the ordinary Romanian soldier removed from his daily routine and sent on the front to defend the borders, as disoriented. His exposure to a climate of rumors and fear about an immanent enemy, built an immunity to human right abuses and made possible criminal acts justifying the defense of national honor, revenge and bloodthirstiness. See Armin Heinen, România, Holocaustul și Logica Violenței (Iași: Editura Universității “Alexandru Ioan Cuza,” 2011), 48.

19 Benjamin (ed.) Comisia Internațională, Documente, 184.

20 Friling, Ioanid, Ionescu (eds.), Final Report, 131.

21 Vladimir Solonari, "Patterns of Violence: The Local Population and the Mass Murder of Jews in Bessarabia and Northern Bukovina. July-August 1941" in Kritika: Explorations in Russian and Eurasian History Vol. 8, No. 4, 2007, 759-760.

22 Jan Tomasz Gross, Revolution from Abroad: The Soviet Conquest of Poland's Western Ukraine and Western Belorussia (Princeton, NJ: Princeton University Press, 1988), 43.

23 The violence in June-July 1941 erupted especially in those localities where different ethnic groups had coexisted peacefully before the war. See Heinen, România, Holocaustul și Logica Violenței, 200; Mark Koller, who was ten years old in 1941 and lived in Vijnița, recalled that the neighbors with whom his father, a lawyer, lived in good and friendly relationships suddenly became his family's enemies. Koller remembered that the Jews' neighbors were looking for ways to rob them and were enthusiastic about it. Later, when the Jews from Vijnița were being jammed into cattle cars, the same neighbors came to witness the developments, jeering at them. The gendarmes had to protect the Jews from the population that was not only hostile but perceived the Jews as targets that had to be eliminated. Koller, M. (1997). Interview 30622. Tape 2, 5:16-5:50, 10.50-11.40. Visual History Archives, USC Shoah Foundation. Retrieved May 6, 2016.

24 Roger Petersen, Understanding Ethnic Violence, Fear, Hatred and Resentment in Twentieth Century Eastern Europe (Cambridge: Cambridge University Press, 2002), 6.

25 Ancel, The History of the Holocaust, 220-221.

26 Solonari, Purifying the Nation, 193-194.

27 Radu Ioanid, The Holocaust in Romania: The Destruction of Jews and Gypsies Under the Antonescu Regime, 1940-1944 (Chicago: Ivan R Dee, 2000), 62.

28 The exact date of the massacre is unknown. According to Ioan Rainer, a resident of Bănilă, the crimes took place "after the war was declared, during the five days in which there was no administration." The violence ended with the arrival of the Romanian army. (United States Holocaust Memorial Museum, RG-25.004M Selected Records from the Romanian Information Service 1936-1948, File 37818, Reel 28, 153)

29 A population census was carried in Romania in 1930, which accounted for three characteristics: nationality, native language and religious denomination. According to the census, out of 868,500 people living in northern Bukovina, 377,100 (43.4\%) were Ukrainian, 273,600 (31.5\%) were Romanian and 102,500 (11.8\%) were Jewish. See Piotr Eberhardt, Ethnic Groups and Population Changes in Twentieth-Century Central-Eastern Europe, History, Data and Analysis (Armonk, NY and London: M.E. Sharpe, 2003), 213.

30 Shmuel Spector and Geoffrey Wigoder (eds.), The Encyclopedia of Jewish Life: before and during the Holocaust (New York: New York University Press, 2001), 84.

31 Mariana Hausleitner, "Evreii și Antisemitismul în Bucovina între 1918 şi 1944" in Studia et Acta Historiae Iudeorum Romaniae, Vol. 8, eds. Dumitru Vitcu and Sivliu Sanie (Bucharest: Hasefer, 2003), 199.

32 C. Enescu is cited by Paul A. Shapiro, "Prelude to Dictatorship in Romania: The National Christian Party in Power December 1937-February 1938" in CanadianAmerican Slavic Studies Vol. VIII, No. 1 (Spring 1974), 61. 
33 Based on the testimonies of defendants Vladimir Klem and Sofia Loy, and witness Ioan Rainer (USHMM, RG-25.004M Selected Records, File 37818, Reel 28, 135, $137,155)$.

34 According to Amalie Marian, the Katz family's daughter. Amalie and her husband Adolf Marian happened to be away on the day of the massacre. Their testimonies are based on the accounts of two survivors, Rosa and Baruch Șloime (USHMM, RG-25.004M Selected Records, File 37818, Reel 28, 105).

35 Adolf Marian's testimony (USHMM, RG-25.004M Selected Records, File 37818, Reel 28, 132).

36 USHMM, RG-25.004M Selected Records, File 37818, Reel 28, 135.

37 USHMM, RG-25.004M Selected Records, File 37818, Reel 28, 155.

38 USHMM, RG-25.004M Selected Records, File 37818, Reel 28, 132-137.

39 USHMM, RG-25.004M Selected Records, File 37818, Reel 28, 137.

40 Solonari, Purifying the Nation, 196-199.

41 Ervin Staub, The Roots of Evil: The Origins of Genocide and Other Group Violence (New York: Cambridge University Press, 1989), 292.

42 Jean Ancel and Théodor Lavi (eds.), Pinkas HaKehilot Romania (Encyclopedia of Jewish Communities: Romania) Vol. II (Jerusalem: Yad Vashem, 1980), 469.

43 Ibid., 470-472.

44 Iacob Blum's testimony (USHMM, RG-25.004M Selected Records, File 1241, Reel $15,180)$.

45 USHMM, RG-25.004M Selected Records, File 1241, Reel 15, 178.

46 According to Iacob Blum, Beniamin Taub and Fani Granirer's testimonies (USHMM, RG-25004M Selected Records, File 1241, Reel 15, 180, 226, 227).

47 USHMM, RG-25.004M Selected Records, File 1241, Reel 15, 180, 177, 226.

48 USHMM, RG-25.004M Selected Records, File 1241, Reel 15, 227.

49 Martha Nims's testimony (USHMM, RG-25.004M Selected Records, File 1241, Reel $15,178)$.

50 According to survivor Beniamin Taub between 75 and 80 Jews were taken from their houses (USHMM, RG-25.004M Selected Records, File 1241, Reel 15, 226); Survivor Rosa Grunich estimated the number to have been 100 (USHMM, RG-25.004M Selected Records, File 1241, Reel 15, 179).

51 USHMM, RG-25.004M Selected Records, File 1241, Reel 15, 178.

52 USHMM, RG-25.004M Selected Records, File 1241, Reel 15, 177.

53 USHMM, RG-25.004M Selected Records, File 1241, Reel 15, 177.

54 USHMM, RG-25.004M Selected Records, File 1241, Reel 15, 179.

55 According to survivor Fani Granirer's deposition (USHMM, RG-25.004M Selected Records, File 1241, Reel 15, 227).

56 USHMM, RG-25.004M Selected Records, File 1241, Reel 15, 227.

57 USHMM, RG-25.004M Selected Records, File 1241, Reel 15, 227.

58 USHMM, RG-25.004M Selected Records, File 1241, Reel 15, 177.

59 USHMM, RG-25.004M Selected Records, File 1241, Reel 15, 178.

60 USHMM, RG-25.004M Selected Records, File 1241, Reel 15, 177.

61 USHMM, RG-25.004M Selected Records, File 1241, Reel 15, 177-227.

62 USHMM, RG-25.004M Selected Records, File 1241, Reel 15, 274.

63 John-Paul Himka, "Western Ukraine between the Wars" in Canadian Slavonic Papers/Revue Canadienne de Slavistes, Vol. 34, No. 4 (December 1992), 399.

64 Hausleitner is cited by Vladimir Solonari in "The Treatment of the Jews of Bukovina by the Soviet and Romanian Administrations in 1940-1944" in Holocaust and Modernity, No. 2 (8) 2010, 151.

65 Himka, "Western Ukraine," 410.

66 Hausleitner, "Evreii și Antisemitismul în Bucovina între 1918 şi 1944,” 199; Alti Rodal also showed that on the eve of the German-Soviet war, the central leadership 
of the OUN network in Bukovina dispatched guidelines to form armed units whose mission was to assume control of the villages and towns with the purpose of creating state structures. See Alti Rodal, "A Village Massacre: The Particular and the Context" in Romania and the Holocaust, ed. Simon Geissbühler (Stuttgart: Ibidem, 2016), 77.

67 Unlike the Romanians, who perceived the OUN as a "national enemy," in July 1941 the Germans saw them as allies in the fight against the Soviet Union and Communism. See Solonari, Purifying the Nation, 182.

68 Vladimir Solonari has shown that Ukrainian nationalists were murdering the Jews in northern Bukovina as part of their campaign to take control over Bukovina and create an ethnically pure Ukrainian state. See Solonari, Purifying the Nation, 181.

69 Rodal, "A Village Massacre," 87-88.

70 Kai Struve, "Anti-Jewish Violence in the Summer of 1941" in Romania and the Holocaust, ed. Simon Geissbühler, (Stuttgart: Ibidem, 2016), 95.

71 Himka, "Western Ukraine," 411.

72 Solonari, Purifying the Nation, 196-199.

73 Geissbühler, "He Spoke Yiddish Like a Jew'," 438-440; Along the same lines, Martin Dean described the massacres which took place in Belorussia and Ukraine under German occupation as taking the form of a macabre ritual in which policemen became intoxicated in celebration of their newfound wealth and Christian locals came along to witness the "entertainment." See Dean, Collaboration in the Holocaust, 164.

74 See Christian Gerlach, "Extremely violent societies: an alternative to the concept of genocide" in Journal of Genocide Research (2006), 8(4) December, 462.

75 USHMM, RG-25.004M Selected Records, File 40021 Vol. 3, Reel 151, 2.

76 S. J. Seidmann, "Kotzman" in Geschichte der Juden in der Bukowina (The History of the Jews in Bukovina) Vol.II, ed. Hugo Gold (Tel Aviv: Olamenu Publishers, 1962), 90.

77 USHMM, RG-25.004M Selected Records, File 40021 Vol. 3, Reel 151, 43.

78 Arnold Auerbach's testimony (USHMM, RG-25.004M Selected Records, File 40021 Vol. 3, Reel 151, 43).

79 USHMM, RG-25.004M Selected Records, File 40021 Vol. 3, Reel 151, 43.

80 Leizer Gherdner's testimony (USHMM, RG-25.004M Selected Records, File 40021 Vol. 3, Reel 151, 5).

81 USHMM, RG-25.004M Selected Records, File 40021 Vol. 3, Reel 151, 3.

82 USHMM, RG-25.004M Selected Records, File 40021 Vol. 3, Reel 151, 45.

83 Ronald Headland, Messages of Murder: A Study of the Reports of the Einsatzgruppen of the Security Police and the Security Service, 1941-1943 (Teaneck, NJ: Fairleigh Dickinson University Press, 1992), 131.

84 Solonari, Purifying the Nation, 181.

85 Jean Ancel (ed.), Documents Concerning the Fate of the Romanian Jewry during the Holocaust Vol. 5 Bessarabia, Bukovina, Transnistria: extermination and survival (New York: Beate Klarsfeld Foundation, 1986), 426.

86 Ion Popescu, Constantin Ungureanu, Românii din Ucraina între trecut şi viitor. Românii din regiunea Cernăuți (Oradea, Romania: Primus, 2010), 131.

87 Constantin Ungureanu, Bucovina în perioada stăpânirii austriece (1775-1918) (Chișinău: Civitas, 2003), 131.

88 Spector and Wigoder (eds.), The Encyclopedia of Jewish Life, 511.

89 Jean Ancel, The Economic Destruction of Romanian Jewry (Jerusalem: Yad Vashem, 2007), 217.

90 USHMM, RG-25.004M Selected Records, File 40021 Vol. 3, Reel 151, 421.

91 Elisabeth Jean Wood, "Armed Groups and Sexual Violence: When is Wartime Rape Rare” in Politics Society Vo. 37, No. 131 (2009), 140-141.

92 Simon Geissbühler, "The Rape of Jewish Women and Girls during the First Phase of the Romanian Offensive in the East, July 1941: A Research Agenda and Preliminary Findings" in Holocaust Studies, Vol. 19, No. 1 (Summer 2013), 69. 
93 Heinen, România, Holocaustul și Logica Violenței, 195.

94 Ancel (ed.), Documents Concerning the Fate of the Romanian Jewry, 426.

95 USHMM, RG-25.004M Selected Records, File 20521, Reel 23, 421-424.

96 USHMM, RG-25.004M Selected Records, File 40021 Vol. 3, Reel 151, 412.

97 USHMM, RG-25.004M Selected Records, File 40021 Vol. 3, Reel 151, 423.

98 USHMM, RG-25.004M Selected Records, File 20521, Reel 23, 422.

99 USHMM, RG-25.004M Selected Records, File 40021 Vol. 3, Reel 151, 424.

100 USHMM, RG-25.004M Selected Records, File 40021 Vol. 3, Reel 151, 412.

101 The readiness to participate throughout Eastern Europe was also highlighted by Alexander B. Rossino, who established that by mid-summer 1941 intense anti-Jewish feeling was at its peak in the wake of the Soviet occupation and that without a large number of Romanians, Belorussians, Ukrainians, Poles, Latvians and Lithuanians being prepared to join in the destruction of Jewish communities, the dynamic of agitation, pogrom and reprisal would not have developed. See Alexander B. Rossino, "Polish 'Neighbors' and German Invaders: Contextualizing Anti-Jewish Violence in the Białystok District during the Opening Weeks of Operation Barbarossa" in Studies in Polish Jewry, Vol. 16 (2003), 451.

102 Jews were not the only ethnic group to welcome the Red Army during the Soviet takeover of Bessarabia and northern Bukovina in June 1940. So too did Romanians, Ukrainians, Russians and Bulgarians - see Ancel, The History of the Holocaust, 72. Most of the local officials who assumed positions in the Communist bureaucracy after the Soviet takeover were Romanian. Romanian army investigations showed that before the Soviets began their deportations from Bessarabia, 505 officials were Romanian and only 69 Jews. In the southern Bessarabian city of Bolgrad, Bulgarian ethnics were among the local minorities reported to have humiliated the withdrawing Romanian army. See Dennis Deletant, Hitler's Forgotten Ally. Ion Antonescu and His Regime, Romania 1940-1944 (London and New York: Palgrave Macmillan, 2006), 17.

103 United States Holocaust Memorial Museum, Accession Number 2011.357.1, Asriel Waldman, The Fine Line, 59.

104 United States Holocaust Memorial Museum, Accession Number 1996.A.0406, Leoniu Rones, Cariera de Piatra (Stone Quarry), 1.

105 United States Holocaust Memorial Museum, RG-02.089, Pearl Fichman, Before Memories Fade, 57.

106 USHMM, Fichman, Before Memories Fade, 60.

107 Petersen, Understanding Ethnic Violence, 4.

108 Brian Lickel, "Retribution and Revenge" in The Oxford Handbook of Intergroup Conflict, ed. Linda R. Tropp (New York: Oxford University Press, 2012), 90.

109 Michael Mann, The Dark Side of Democracy: Explaining Ethnic Cleansing (New York: Cambridge University Press, 2005), 25-26.

110 Petersen, Understanding Ethnic Violence, 3.

111 Lya Benjamin (ed.), Evreii din România între anii 1940-1944 Vol. II. Problema Evreiască în Stenogramele Consiliului de Miniștri (Bucharest: Hasefer, 1996), 331.

112 Diana Dumitru, "Peasants' Perceptions of Jewish Life in Interwar Bessarabia and how this became Interwoven into the Holocaust" in Plural, Vol. I, No.1-2, (2013), $136-137$.

113 Ancel (ed.), Documents Concerning the Fate of the Romanian Jewry, 426.

114 USHMM, RG-25.004M Selected Records, File 1241, Reel 15, 178.

115 Postwar trial documents specify the presence or absence of a criminal record for perpetrators in three out of the four Bessarabian villages discussed in this chapter. Out of 20 culprits only one had a criminal record. The youngest of the perpetrators from all the four villages was 19 and the oldest was 68 years old (United States Holocaust Memorial Museum, RG-54.003 War Crimes Investigation and Trial 
Records from the Republic of Moldova 1944-1955, Acc.2004.691, File 28002, 267; File 20855, 399).

116 Solonari, "Patterns of Violence," 767-768.

117 Oral History Interview with David Popa, RG-50.572*0115, Tape 1, 19:06; Oral History Interview with Elena Bufteac, RG-50.572*0123, Tape 1, 01:13:14-01:14:03.

118 Dumitru, State, Antisemitism and Collaboration, 86.

119 United States Holocaust Memorial Museum, Moldova Documentation Project 2008 Oral History Interview with Silvestru Băț, RG-50.572*0117 Tape 1, 20:14-20:50. Accessed September 3, 2016.

120 Tartakovsky, "Parallel Ruptures," 197.

121 C. Enescu is cited by Shapiro, "Prelude to Dictatorship in Romania," 60.

122 Martin Gilbert, The Routledge Atlas of the Holocaust. 4th edition (New York: Routledge, 2009), 70.

123 Friling, Ioanid, Ionescu (eds.), Final Report, 106.

124 USHMM, RG-54.003 War Crimes Investigation and Trial Records Acc.2004.691, File 28581, 336-337, 435.

125 USHMM, RG-54.003 War Crimes Investigation and Trial Records Acc.2004.691, File 28581,338-339; United States Holocaust Memorial Museum, Moldova Documentation Project 2008Oral History Interview with David Popa, RG-50.572*0115, Tape 1, 12:07-12:12.

126 USHMM, RG-54.003 War Crimes Investigation and Trial Records Acc.2004.691, File 28581, 340; USHMM, Oral History Interview with Silvestru Băţ, RG-50.572*0117, Tape 1, 11:20.

127 United States Holocaust Memorial Museum, Moldova Documentation Project 2008 Oral History Interview with Ion Vărzari RG-50.572*0124, Tape 1, 01:12:26.

128 USHMM, RG-54.003 War Crimes Investigation and Trial Records Acc.2004.691, File 28581, 432-433.

129 USHMM, RG-54.003 War Crimes Investigation and Trial Records Acc.2004.691, File 18143 Vol. II, 930.

130 Ancel and Lavi (eds.) Pinkas Hakehilot Vol.II, 351.

131 Spector and Wigoder (eds.) The Encyclopedia of Jewish Life, 1373.

132 Gilbert, The Routledge Atlas, 70.

133 Ancel, The History of the Holocaust, 231.

134 USHMM, RG-54.003 War Crimes Investigation and Trial Records Acc.2004.691, File 20867, 164-165.

135 USHMM, RG-54.003 War Crimes Investigation and Trial Records Acc.2004.691, File 20849, 262.

136 USHMM, RG-54.003 War Crimes Investigation and Trial Records Acc.2004.691, File $20867,164$.

137 USHMM, RG-54.003 War Crimes Investigation and Trial Records Acc.2004.691, File 18143 Vol.2, 930-933.

138 USHMM, RG-54.003 War Crimes Investigation and Trial Records Acc.2004.691, File $20867,164$.

139 USHMM, RG-54.003 War Crimes Investigation and Trial Records Acc.2004.691, File 18143 Vol. II, 931.

140 USHMM, RG-54.003 War Crimes Investigation and Trial Records Acc.2004.691, File 20867, 163.

141 USHMM, RG-54.003 War Crimes Investigation and Trial Records Acc.2004.691, File 20849, 268.

142 USHMM, RG-54.003 War Crimes Investigation and Trial Records Acc.2004.691, File 18143 Vol.2, 929-930.

143 USHMM, RG-54.003 War Crimes Investigation and Trial Records Acc.2004.691, File $5360,1-2$. 
144 USHMM, RG-54.003 War Crimes Investigation and Trial Records Acc.2004.691, File 28002, 267-269.

145 USHMM, RG-54.003 War Crimes Investigation and Trial Records Acc.2004.691, File 5360, 1.

146 USHMM, RG-54.003 War Crimes Investigation and Trial Records Acc.2004.691, File 20855, 369.

147 United States Holocaust Memorial Museum, Moldova Documentation Project 2008 Oral History Interview with Andrei Vulpe RG-50.572*0118, Tape 1, 01.30-8.00.

148 USHMM, RG-54.003 War Crimes Investigation and Trial Records Acc.2004.691, File 20855, 400.

149 USHMM, RG-54.003 War Crimes Investigation and Trial Records Acc.2004.691, File 20855, 404.

150 USHMM, RG-54.003 War Crimes Investigation and Trial Records Acc.2004.691, File 20855, 400-403; USHMM, Oral History Interview with Andrei Vulpe RG-50.572*0118, Tape 1, 41:30-43:05.

151 USHMM, RG-54.003 War Crimes Investigation and Trial Records Acc.2004.691, File 20855, 398-402.

152 Dumitru, "Peasants' Perceptions," 136-137.

153 Ted Robert Gurr, Why Men Rebel (Princeton, NJ: Princeton University Press, 1970), 13.

154 Ervin Staub, The Psychology of Good and Evil: Why children, adults, and groups help and harm others (New York: Cambridge, 2003), 294.

155 Victoria Barnett, Bystanders. Conscience and Complicity During the Holocaust (Westport, CT and London: Praeger, 1999), 27-29.

156 Dumitru, The State, Antisemitism and Collaboration, 158.

157 Dumitru, "Peasants' Perceptions," 147.

158 Dumitru, The State, Antisemitism and Collaboration, 174. That social solidarity and moral empathy between Jews and non-Jews disappeared after re-annexation was also confirmed by Gleb Ciudacov, a resident of the Bessarabian village of Hâncești, who described the local atmosphere at the time as one of "looking out for your own interest." Talking to Jews was looked upon unfavorably, and because Ciudacov didn't sever all ties with local Jews, he was denied a certificate of good behavior. (United States Holocaust Memorial Museum, RG.50.573*0016 Romania Documentation Project, Gleb Ciudacov, 01:14-15)

159 Ancel, The History of the Holocaust, 221.

160 Petersen, Understanding Ethnic Violence, 3.

161 USHMM, RG-25004M Selected Records, File 22539, Reel 16, 157.

162 Diana Dumitru and Carter Johnson, "Constructing Interethnic Conflict and Cooperation. Why Some People Helped Jews and Others Harmed Them during the Holocaust in Romania" in World Politics 63, No. 1, (January 2011), 2.

163 Erich Fromm, The Anatomy of Human Destructiveness (London: Jonathan Cape, 1974), 66-68.

164 Harald Welzer, "On Killing and Morality: How Normal People Become Mass Murderers" in Ordinary People as Mass Murderers: Perpetrators in Comparative Perspectives, eds. Olaf Jensen and Claus Christian W. Sznejnmann (London and New York: Palgrave Macmillan, 2008), 168.

165 In areas where no deep-seated antisemitic discourse existed, such as Subcarpathian Rus, the anti-Jewish resentment of the indigenous population was not propelled into mass violence. See Raz Segal, Genocide in the Carpathians, War, Social Breakdown and Mass Violence 1914-1945 (Stanford, CA: Stanford University Press, 2016), 105.

166 Dumitru, The State, Antisemitism and Collaboration, 174.

167 Ibid., 10.

168 Solonari, Purifying the Nation, 194. 
169 Solonari reaches the same conclusion in regard to the massacre in the Bukovinian village of Nepolocăuți. See Solonari, "Patterns of Violence," 767.

170 Martin Dean, Collaboration in the Holocaust: Crimes of the Local Police in Belorussia and Ukraine, 1941-1944 (New York: St. Martin's Press, 2000), viii.

\section{Chapter 2}

1 Jean Ancel, The History of the Holocaust in Romania (Lincoln, NE and Jerusalem: University of Nebraska Press and Yad Vashem, 2011), 244.

2 Marcel-Dumitru Ciucă, Maria Ignat (eds.) Stenogramele Ședințelor Consiliului de Miniștri. Guvernarea Ion Antonescu. Vol. V, Octombrie 1941, ianuarie 1942 (Bucharest: Arhivele Naționale ale României, 2001), 323.

3 Dennis Deletant, Hitler's Forgotten Ally. Ion Antonescu and His Regime, Romania 1940-1944 (London and New York: Palgrave Macmillan, 2006), 323 (note 20).

4 Ciucă, Ignat (eds.) Stenogramele Ședințelor Consiliului de Miniștri, Vol. V, 153.

5 Christopher R. Browning, "Before the "Final Solution": Nazi Ghettoization Policy in Poland (1940-1941)" in Ghettos 1939-1945 New Research and Perspectives on Definition, Daily Life and Survival Symposium Presentations (Washington, DC: Center for Advanced Holocaust Studies United States Holocaust Memorial Museum, 2005), 3.

6 Deletant, Hitler's Forgotten Ally, 152.

7 Diana Dumitru, State, Antisemitism and Collaboration in the Holocaust: The Borderlands of Romania and the Soviet Union (New York: Cambridge University Press, 2016), 10.

8 Ervin Staub, Overcoming Evil. Genocide, Violent Conflict and Terrorism (New York: Oxford University Press, 2011), 173-174.

9 Lotti Kahana-Aufleger, a survivor from Cernăuți, recalled how the Romanian couple Kazacu offered their assistance as the ghettoization of the Jews was being initiated and promised they would watch over the family's belongings. After Lotti and her family were sent into the ghetto, the Kazacus came to update them about all the orders as well as offered to change their gold watches with simple watches. They pledged to return the watches and other items with which they were entrusted upon the family's return. When the time came for Lotti's husband to ask for the family's belongings back, the Kazacus slammed the door in his face. He then approached the couple in public with the same plea only to be threatened that they would have them all deported to Transnistria (United States Holocaust Memorial Museum, DS135.U43 K246 1990, Lotti Kahana-Aufleger, Survival, 20-29).

10 Vladimir, Solonari. Purifying the Nation: Population Exchange and Ethnic Cleansing in Nazi-Allied Romania, (Washington, DC and Baltimore: Woodrow Wilson Center Press and Johns Hopkins University Press, 2010), 209.

11 Fred Skolnik (ed.), Encyclopedia Judaica, 2nd edition (Jerusalem: The Jerusalem Publishing House/Thomson Gale, 2007), 117.

12 Dumitru, The State, Antisemitism and Collaboration, 87.

13 C. Enescu is cited by Paul A. Shapiro, "Prelude to Dictatorship in Romania: The National Christian Party in Power December 1937-February 1938" in CanadianAmerican Slavic Studies Vol. VIII, No. 1 (Spring 1974), 60.

14 Tuvia Friling, Radu Ioanid, Mihail E. Ionescu (eds.) Final Report of the International Commission on the Holocaust in Romania, (Iași, Romania: Polirom, 2005), 82.

15 United States Holocaust Memorial Museum, RG-25.004M Selected Records from the Romanian Information Service 1936-1948, Reel 23, File 20521, 176.

16 USHMM, RG-25.004M Selected Records, Reel 23, File 20521, 175-176.

17 USHMM, RG-25.004M Selected Records, Reel 23, File 20521, 189.

18 USHMM, RG-25.004M Selected Records, Reel 23, File 20521, 315. 
19 USHMM, RG-25.004M Selected Records, Reel 23, File 40011, 316.

20 USHMM, RG-25.004M Selected Records, Reel 23, File 40011, 189.

21 Simon Levis Sullam, The Italian Executioners: The Genocide of the Jews of Italy (Princeton, NJ: Princeton University Press, 2018), 112.

22 If retaliation against the Jews for their actions against retreating Romanian troops in June 1940 was a reason for deportation, then it was unjustified to also include the Jews in southern Bukovina and Dorohoi county in northern Moldavia, which were not annexed by the Soviet Union in June 1940 and remained part of Romania. See Dennis Deletant "Aspects of the Ghetto Experience in Eastern Transnistria: The Ghettos and Labor Camp in the Town of Golta" in Ghettos 1939-1945 New Research and Perspectives on Definition, Daily Life and Survival Symposium Presentations (Washington, DC: Center for Advanced Holocaust Studies United States Holocaust Memorial Museum, 2005), 18.

23 According to Solomon Zalman, one of the Jewish leaders at the time (USHMM, RG-25.004M Selected Records, Reel 19, File 40011, 247).

24 USHMM, RG-25.004M Selected Records, Reel 150, File 40011, 34-35.

25 Ancel, Jean and Lavi, Théodor (eds.) Pinkas Hakehilot (Encyclopedia of Jewish Communities: Romania) Volume I (Jerusalem: Yad Vashem, 1969), 105.

26 Ibid., 106.

27 Ibid., 107.

28 C. Enescu is cited by Shapiro, "Prelude to Dictatorship in Romania," 60.

29 Radu Ioanid, The Holocaust in Romania: The Destruction of Jews and Gypsies Under the Antonescu Regime, 1940-1944 (Chicago: Ivan R Dee, 2000), 159.

30 Jean Ancel, The Economic Destruction of Romanian Jewry (Jerusalem: Yad Vashem, 2007), 219.

31 USHMM, RG-25.004M Selected Records, Reel 19, File 40011, 247.

32 USHMM, RG-25.004M Selected Records, Reel 19, File 40011, 66-67.

33 USHMM, RG-25.004M Selected Records, Reel 19, File 40011, 266.

34 USHMM, RG-25.004M Selected Records, Reel 19, File 40011, 248.

35 USHMM, RG-25.004M Selected Records, Reel 150, File 40021, 35.

36 USHMM, RG-25004M Selected Records, Reel 19, File 40011, 248.

37 USHMM, RG-25004M Selected Records, Reel 19, File 40011, 248.

38 Dennis Deletant, Hitler's Forgotten Ally. Ion Antonescu and His Regime, Romania 1940-1944 (London and New York: Palgrave Macmillan, 2006), 158.

39 Ancel, The Economic Destruction, 222.

40 Idem.

41 USHMM, RG-25.004M Selected Records, Reel 19, File 40011, 248.

42 Raz Segal, Genocide in the Carpathians, War, Social Breakdown and Mass Violence 1914-1945 (Stanford, CA: Stanford University Press, 2016), 95.

43 Sullam, The Italian Executioners, 77-88.

44 Jean Ancel and Théodor Lavi (eds.), Pinkas HaKehilot Romania (Encyclopedia of Jewish Communities: Romania) Vol. II (Jerusalem: Yad Vashem, 1980), 386.

45 Ibid., 388.

46 Friling, Ioanid, Ionescu (eds.), Final Report, 130.

47 On July 11, the commandant of Einsatzkommando 10b, a subunit of Einsatzgruppe $\mathrm{D}$, reported the large-scale occurrence of looting in Fălești and complained about the lack of a coherent plan for the measures taken against the Jews by the Romanian authorities. See Friling, Ioanid, Ionescu (eds.), Final Report, 134; Diana Dumitru highlighted that a large number of villagers from Fălești and its surroundings systematically looted the victims at the war's onset. One local perpetrator described the state of affairs in his testimony: "Almost all Moldovan people who had horses and carts were involved in the robbery and theft, about 5,000 Jews lived in the town, and we threw them outside their houses without any bread and clothes, and their property remained at the free-will of fate, and it was stolen." See Diana Dumitru, "Peasants' 
Perceptions of Jewish Life in Interwar Bessarabia and how this became Interwoven into the Holocaust" in Plural, Vol. I, No. 1-2 (2013), 145.

48 Similar to the camps in Limbenii Noi and Bălți, the one in Fălești was a transit camp for the future deportees to Transnistria. Jean Ancel is cited by Friling, Ioanid, Ionescu (eds.), Final Report, 343.

49 United States Holocaust Memorial Museum, RG-54.003 War Crimes Investigation and Trial Records from the Republic of Moldova 1944-1955 Acc.2004.691, File 020970, 1.

50 USHMM, RG-54.003 War Crimes Investigation and Trial Records Acc.2004.691, File 020970, 197-198.

51 USHMM, RG-54.003 War Crimes Investigation and Trial Records Acc.2004.691, File 020970, 199-200.

52 USHMM, RG-54.003 War Crimes Investigation and Trial Records Acc.2004.691, File 18530, 74.

53 USHMM, RG-54.003 War Crimes Investigation and Trial Records Acc.2004.691, File 18530, 96.

54 USHMM, RG-54.003 War Crimes Investigation and Trial Records Acc.2004.691, File 18530, 73.

55 USHMM, RG-54.003 War Crimes Investigation and Trial Records Acc.2004.691, File 18530, 72.

56 USHMM, RG-54.003 War Crimes Investigation and Trial Records Acc.2004.691, File 18530, 97.

57 USHMM, RG-54.003 War Crimes Investigation and Trial Records Acc.2004.691, File $18530,75$.

58 USHMM, RG-54.003 War Crimes Investigation and Trial Records Acc.2004.691, File $18530,75$.

59 USHMM, RG-54.003 War Crimes Investigation and Trial Records Acc.2004.691, File 18530, 73.

60 USHMM, RG-54.003 War Crimes Investigation and Trial Records Acc.2004.691, File 18530, 98.

61 USHMM, RG-54.003 War Crimes Investigation and Trial Records Acc.2004.691, File 18530, 74.

62 Friling, Ioanid, Ionescu (eds.), Final Report, 177.

63 Ibid., 259-260.

64 Paul Shapiro, The Kishinev Ghetto 1941-1942, A Documentary History of the Holocaust in Romania's Contested Borderlands (Tuscaloosa, AL: The University of Alabama Press, 2015), 16; Radu Ioanid's date for the ghetto's set up is July 24, 1941. See Ioanid, The Holocaust in Romania, 124; According to Vladimir Solonari, the ghetto was established on July 22, 1941. See Solonari, Purifying the Nation, 200.

65 Shapiro, The Kishinev Ghetto, 19.

66 The Romanian authorities were aware of this state of affairs and endorsed it. In his postwar testimony, Traian Niculescu, Chișinău's District Attorney in 1941, stated that he was aware of the influx of people in the ghetto who wanted to buy clothes and jewelry especially. The rumor circulating in the city at the time was that business was flourishing in the ghetto and that the Jews were being despoiled (USHMM, RG-25.004M Selected Records, Reel 24, File 22725, 199).

67 USHMM, RG-25.004M Selected Records, Reel 24, File 22725, 200.

68 Solonari, Purifying the Nation, 209.

69 USHMM, RG-25.004M Selected Records, Reel 24, File 22725, 190-191.

70 USHMM, RG-25.004M Selected Records, Reel 24, File 22725, 191.

71 USHMM, RG-25.004M Selected Records, Reel 25, File 20725, 286. One hundred lei is the equivalent of approximately $\$ 30$ today.

72 USHMM, RG-25.004M Selected Records, Reel 24, File 22725, 198. 
73 Sullam, The Italian Executioners, 121-124.

74 Avigdor Shachan, Burning Ice. The Ghettos of Transnistria (Boulder, CO: Eastern European Monographs, 1996), 74-81.

75 USHMM, RG-25.004M Selected Records, Reel 24, File 22725, 235.

76 Shapiro, The Kishinev Ghetto, 69-70.

77 Ibid., 74.

78 USHMM, RG-25.004M Selected Records, Reel 65, File 181, 299.

79 USHMM, RG-25.004M Selected Records, Reel 65, File 181, 304-305.

80 USHMM, RG-25.004M Selected Records, Reel 24, File 22725, 168.

81 United States Holocaust Memorial Museum, RG-54.001, Selected Records from the Moldova National Archives: Chișinău, Reel 128, File 6586, 268.

82 United States Holocaust Memorial Museum, RG-25.003M, Selected Records from the Romanian Ministry of Defense 1940-1945, Reel 131, File 32, 327.

83 USHMM, RG-25.003M Selected Records, Reel 131, File 32, 326.

84 USHMM, RG-25.003M Selected Records, Reel 128, File 96, 19-20.

85 USHMM, RG-25.003M Selected Records, Reel 131, File 32, 32.

86 USHMM, RG-25.004M Selected Records, Reel 24, File 22725, 185.

87 Ancel, The Economic Destruction, 178-179.

88 Ancel, The History of the Holocaust, 245-246.

89 Deletant, Hitler's Forgotten Ally, 153.

90 Idem.

91 Ioanid, The Holocaust in Romania, 137.

92 Ancel, The History of the Holocaust, 249.

93 Ibid., 250.

94 Ioanid, The Holocaust in Romania, 137.

95 Idem.

96 Ancel, The Economic Destruction, 179.

97 USHMM, RG-25.004M Selected Records, Reel 29, File 40013, 69.

98 Previous scholars have looked into the crimes committed by Mihăiescu and his team of bank envoys. Radu Ioanid highlighted Mihăiescu and the other officials' greed and sadistic behavior. See Ioanid, The Holocaust in Romania, 137-138; Jean Ancel focused on the magnitude of the plunder committed by Ion Mihăiescu and the rest of bank envoys. See Ancel, The Economic Destruction, 182; Dennis Deletant succinctly described the bank employees' legal and illegal activities in the camp. See Deletant, Hitler's Forgotten Ally, 154.

99 USHMM, RG-25.004M Selected Records, Reel 28, File 40013, 56.

100 Mihăiescu addressed Iacov Blum, another deportee from Rădăuți, with the same words when the latter implored the bank inspector not to take away his certificate of good behavior (USHMM, RG-25.004M Selected Records, Reel 28, File 40013, 86).

101 USHMM, RG-25.004M Selected Records, Reel 28, File 40013, 59-60.

102 Staub, Ervin. The Roots of Evil: The Origins of Genocide and Other Group Violence (New York: Cambridge University Press, 1989), 52.

103 USHMM, RG-25.004M Selected Records, Reel 28, File 40013, 99-100.

104 USHMM, RG-25.004M Selected Records, Reel 28, File 40013, 180.

105 USHMM, RG-25.004M Selected Records, Reel 28, File 40013, 104.

106 USHMM, RG-25.004M Selected Records, Reel 28, File 40013, 105.

107 USHMM, RG-25.004M Selected Records, Reel 28, File 40013, 181.

108 USHMM, RG-25.004M Selected Records, Reel 28, File 40013, 82.

109 USHMM, RG-25.004M Selected Records, Reel 28, File 40013, 96.

110 USHMM, RG-25.004M Selected Records, Reel 28, File 40013, 118.

111 USHMM, RG-25.004M Selected Records, Reel 28, File 40013, 17-18.

112 USHMM, RG-25.004M Selected Records, Reel 28, File 40013, 52.

113 USHMM, RG-25.004M Selected Records, Reel 28, File 40013, 108. 
114 USHMM, RG-25.004M Selected Records, Reel 28, File 40013, 110.

115 USHMM, RG-25.004M Selected Records, Reel 28, File 40013, 168.

116 USHMM, RG-25.004M Selected Records, Reel 28, File 40013, 53-54.

117 Staub, The Roots of Evil, 236.

118 USHMM, RG-25.004M Selected Records, Reel 28, File 40013, 57.

119 Radu Ioanid indicated that attempts to bring into Romania letters on behalf of Jews deported to Transnistria were made even by non-Jewish civilians or by military officials. See Ioanid, The Holocaust in Romania, 291.

120 Benjamin Grilj (ed.), Schwarze Milch: Zurückgehaltene Briefe aus den Todeslagern Transnistriens (Innsbruck: Studien Verlag 1st ed. German/English/Romanian/ Ukrainian, 2013), 221.

121 Ibid., 189.

122 Ibid., 309.

123 Ibid., 287.

124 Ibid., 663.

125 Ibid., 713.

126 Ibid., 731.

127 Ibid., 199.

128 Ibid., 849.

129 Ibid., 957.

130 Dan Bar-On, "The Bystander in Relation to the Victim and the Perpetrator: Today and During the Holocaust" in Social Justice Research Vol. 14, No. 2 (June 2001), 134.

131 Ancel, The History of the Holocaust, 244.

132 Staub, Overcoming Evil, 169-170.

133 Bar-On, "The Bystander in Relation to the Victim and the Perpetrator," 144-145.

134 Raul Hilberg, The Destruction of the European Jews, Vol. II (New Haven, CT and London: Yale University Press, 2003), 809.

\section{Chapter 3}

1 Vladimir Solonari, Purifying the Nation: Population Exchange and Ethnic Cleansing in Nazi-Allied Romania, (Washington, DC and Baltimore, MD: Woodrow Wilson Center Press and Johns Hopkins University Press, 2010), 216-217.

2 See, for instance, Ștefan Cristian Ionescu, Jewish Resistance to "Romanianization", 1940-1944 (London and New York: Palgrave Macmillan, 2015), 7. Similar objectives were being pursued in other Nazi-allied countries such as Hungary and Slovakia. In Slovakia, Slovakianization was going to establish a solid Slovak middle class, selfreliant and influential in the life of the nation. See Tatjana Tönsmeyer "The Robbery of Jewish Property in Eastern Europe States Allied with Nazi Germany" in Martin Dean, Constantin Goschler, Philipp Ther (eds.) Robbery and Restitution: The Conflict over Jewish Property in Europe (New York, Oxford: Berghahn Books, 2008), 85.

3 Radu Ioanid, The Holocaust in Romania: The Destruction of Jews and Gypsies Under the Antonescu Regime, 1940-1944 (Chicago: Ivan R Dee, 2000), 24.

4 Ibid., 248.

5 Lya Benjamin (ed.), Evreii din România între anii 1940-1944 Vol.II. Problema Evreiască în Stenogramele Consiliului de Miniștri, 304-305.

6 Ibid., 305.

7 Ioanid, The Holocaust in Romania, 26.

8 United States Holocaust Memorial Museum, RG-25.024M Selected Records of the Romanian Ministry of Work, Health and Central Protection - Central Office of Romanianization (Aryanization) 1939-1944, Reel 4, File 697, 816.

9 United States Holocaust Memorial Museum, RG-25.003M Selected Records from the Romanian Ministry of Defense 1940-1945, Reel 22, File 6262. 
10 Jean Ancel, The Economic Destruction of Romanian Jewry (Jerusalem: Yad Vashem, 2007), 212.

11 USHMM, RG-25.024M Selected Records, Reel 13, File 740, 999.

12 USHMM, RG-25.024M Selected Records, Reel 25, File 648, 170.

13 United States Holocaust Memorial Museum, RG-54.004M Selected Records of the Liaison Office (under the Office of the Chairman of the Council of Ministers) for Bessarabia, Bukovina and Transnistria, 1941-1944, Reel 3, File 11, 450.

14 USHMM, RG-25.024M Selected Records, Reel 11, File 9, 630.

15 Robert Gellately, "Denunciations in XX Century Germany: Aspects of Self-Policing in the Third Reich and The German Democrat Republic" in The Journal of Modern History Vol. 68 (December 1996), 950.

16 Romanians who feared the Soviets and whose families were not divided by the annexation, Ukrainians with nationalist leanings and German ethnics who were active antiCommunists moved out of Bukovina before the region was formally ceded to the Soviet Union. See Andrej Angrick, "Power Games: The German Nationality Policy (Volkstumspolitik) in Czernowitz before and during the Barbarossa Campaign" in Dapim: Studies on the Holocaust Vol. 24 (2010), 105.

17 USHMM, RG-25.024M Selected Records, Reel 17, File 16, 572-573.

18 Tuvia Friling, Radu Ioanid and Mihail E. Ionescu (eds.) Final Report of the International Commission on the Holocaust in Romania, (Iași: Polirom, 2005), Final Report, 191.

19 Solonari, Purifying the Nation, 248-249.

20 USHMM, RG-25.024M Selected Records, Reel 15, File 14, 837-838.

21 Roland Clark, "Claiming Ethnic Privilege: Aromanian Immigrants and Romanian Fascist Politics" in Contemporary European History, Vol. 24, Issue 1, February 2015, 56.

22 USHMM, RG-25.024M Selected Records, Reel 17, File 16, 601-602.

23 Zoltán Vági, Lászlo Csősz and Gábor Kádár (eds.), The Holocaust in Hungary: Evolution of a Genocide (Lanham, MD: AltaMira Press, 2013), 285.

24 Thomas Kühne, Belonging and Genocide, Hitler's Community 1918-1945 (New Haven, CT and London: Yale University Press, 2010), 5.

25 See Mihail Sebastian, Jurnal 1935-1944 (Bucharest: Humanitas, 1996), 319.

26 Ionescu, Jewish Resistance to "Romanianization," 79.

27 USHMM, RG-25.024M Selected Records, Reel 17, File 16, 716.

28 Ionescu, Jewish Resistance to "Romanianization," 71.

29 USHMM, RG-25.024M Selected Records, Reel 11, File 9, 1130.

30 USHMM, RG-25.024M Selected Records, Reel 13, File 12, 233.

31 USHMM, RG-25.024M Selected Records, Reel 16, File 14, 621-622.

32 Ionescu, Jewish Resistance to "Romanianization," 83.

33 United States Holocaust Memorial Museum, RG-31.006M Czernowitz Oblast Archives Records, Reel 37, File 6, 210.

34 USHMM, RG-31.006M Czernowitz Oblast, Reel 37, File 4, 674-676.

35 USHMM, RG-54.004M Selected Records, Reel 4, File 14, 657.

36 USHMM, RG-54.004M Selected Records, Reel 4, File 14, 657.

37 Mark Levene, Genocide in the Age of the Nation State, Vol. 1, The Meaning of Genocide (New York: I. B. Tauris, 2005), 130.

38 David Norman Smith, "The Social Construction of Enemies: Jews and the Representation of Evil" in Sociological Theory Vol. 14, No. 3 (November 1996), 233.

39 Mariana Hausleitner, "Jewish Communist Gangs in Czernowitz?" in Simon Geissbühler (ed.) Romania and the Holocaust (Stuttgart: Ibidem, 2016), 19.

40 Jean Ancel (ed.) Wilhelm Filderman: Memoirs and Diaries Vol. 1, 1900-1940 (Jerusalem: Tel Aviv University and Yad Vashem, 2004), 512.

41 Ancel, The Economic Destruction, 216. 
42 USHMM, RG-31.006M Czernowitz Oblast, Reel 37, File 6, 678-679.

43 Ancel, The Economic Destruction, 208. According to Armin Heinen, large-scale corruption acted almost as a blessing because it created an alliance of interests between the Romanian administration and the Jewish population, providing the latter with protection. See Armin Heinen, România, Holocaustul și Logica Violenței (Iași: Editura Universităţii “Alexandru Ioan Cuza,” 2011), 109.

44 USHMM, RG-25.003M Selected Records, Reel 22, File 6262.

45 USHMM, RG-25.003M Selected Records, Reel 22, File 6262.

46 USHMM, RG-54.004M Selected Records, Reel 5, File 16, 216.

47 USHMM, RG-31.006M Czernowitz Oblast, Reel 34, File 73, 692.

48 USHMM, RG-31.006M Czernowitz Oblast, Reel 34, File 73, 692.

49 USHMM, RG-31.006M Czernowitz Oblast, Reel 34, File 73, 692-695.

50 USHMM, RG-31.006M Czernowitz Oblast, Reel 35, File 73, 245-246.

51 In addition to playing an important role in the regional economy where Jews comprised 35 percent of all industrial workers, more than 17 percent of workers in transport businesses and managing more than 66 percent of credit extension operations, Jews were also in control of a substantial segment of the lumber industry, which was a pillar of the region's economy. See Vladimir Solonari, "The Treatment of the Jews of Bukovina by the Soviet and Romanian Administrations in 1940-1944," Holocaust and Modernity, No. 2 (8) 2010, 150.

52 Mihai-Ștefan Ceaușu, "Structura economico-socială a populației evreiești din Bucovina (1848-1914)" in Dumitru Vitcu and Sivliu Sanie (eds.) Studia et Acta Historiae Iudeorum Romaniae Vol. VI (Bucharest: Hasefer, 2001), 191.

53 USHMM, RG-31.006M Czernowitz Oblast, Reel 27, File 76, 396.

54 USHMM, RG-31.006M Czernowitz Oblast, Reel 27, File 76, 396.

55 USHMM, RG-31.006M Czernowitz Oblast, Reel 27, File 76, 391.

56 USHMM, RG-31.006M Czernowitz Oblast, Reel 27, File 76, 396.

57 USHMM, RG-31.006M Czernowitz Oblast, Reel 23, File 18, 69-73.

58 Dennis Deletant, Hitler's Forgotten Ally. Ion Antonescu and His Regime, Romania 1940-1944 (London and New York: Palgrave Macmillan, 2006), 141.

59 USHMM, RG-25.003M Selected Records, Reel 127, File 177, 147.

60 USHMM, RG-25.003M Selected Records, Reel 127, File 177, 147.

61 USHMM, RG-25.003M Selected Records, Reel 127, File 177, 147.

62 USHMM, RG-25.003M Selected Records, Reel 127, File 177, 176.

63 During his postwar trial, Fotin Batog, a gendarme with the Orhei Legion accused of killing three Jews in early July 1941, illuminated the circumstances surrounding his crimes. Batog explained how, according to the local custom, the priest in the Bessarabian village of Budăi welcomed the arriving troops with bread and salt. His next action was to tell the legion's commandant that three Jews were hiding in the village. Ordered to arrest them, Batog complied and then executed the three people on the village's outskirts (United States Holocaust Memorial Museum, RG-25.004M, Selected Records from the Romanian Information Service 1936-1948, Reel 16, File 22539, 30). Sergeant Major Ioan Munteanu of the Cornova Gendarmes station in Rădeni, Călărași County, was able to gather intelligence from local people who came to him voluntarily and disclosed their knowledge of Communists and Jews who were still in town. Afterward, the same locals participated in their apprehension (USHMM, RG-25.004M Selected Records, Reel 16, File 22539,213). At Târgul Edineț, the Dorobanți regiment was able to arrest 217 Jews suspected of Communist activity based on the information provided by the Christian population (USHMM, RG-25.004M Selected Records, Reel 83, File 99420, 40).

64 Robert Gellately, Backing Hitler: Consent and Coercion in Nazi Germany (New York: Oxford University Press, 2001), 261. 
65 Simon Levis Sullam, The Italian Executioners: The Genocide of the Jews of Italy (Princeton, NJ: Princeton University Press, 2018), 55.

66 Ibid., 143-144.

67 Based on the records of the German Consulate in Cernăuți, 34,210 people from northern Bukovina requested resettlement prior to August 1940. They included Volksdeutsche and members of foreign nations (Romanians, Ukrainians, Poles, Hungarians, Russians, Czechs, Croats and Armenians) who claimed partial German descent. See Angrick, "Power Games," 109-110.

68 USHMM, RG-31.006M Czernowitz Oblast, Reel 15, File 121, 25-29.

69 USHMM, RG-31.006M Czernowitz Oblast, Reel 15, File 121, 34.

70 The Jews in Cernăuți in fact had more reasons to want to forget their experience of Russian occupation. During that year, numerous Jews lost their jobs as a result of the nationalization of factories, shops, banks, craft businesses, hospitals and pharmacies. Work became mandatory and countless intellectuals as well as civil servants had to perform challenging physical labor. The NKVD targeted for deportation those who were active politically. See Hausleitner, "Jewish-Communist Gangs'," 36.

71 USHMM, RG-31.006M Czernowitz Oblast, Reel 15, File 93, 11-12.

72 Analyzing the patterns of denunciation in Nazi Germany, Robert Gellately concluded that informing tended to prevail within social classes, neighborhoods and apartment houses. See Gellately, Denunciations in Twentieth-Century Germany, 945.

73 USHMM, RG-31.006M Czernowitz Oblast, Reel 22, File 576, 618. After July 1941, it was not uncommon for Jews to be accused of denigrating the state and its authorities. Leizer Reigler, a Jewish baker from Burdujeni, was denounced to the authorities by a Legionnaire sympathizer, Elena Burlacu, for insulting the Antonescu regime. He was detained and fined 200,000 lei (United States Holocaust Memorial Museum, RG-25.051 Records of the World Jewish Congress in Romania, Burdujeni CME4B, 016983).

74 USHMM, RG-31.006M Czernowitz Oblast, Reel 22, File 576, 618.

75 USHMM, RG-31.006M Czernowitz Oblast, Reel 22, File 576, 781.

76 USHMM, RG-31.006M Czernowitz Oblast, Reel 22, File 576, 781.

77 USHMM, RG-31.006M Czernowitz Oblast, Reel 22, File 576, 781.

78 Survivor Haim Steinberg described how, in early July 1941, one of his acquaintances, a Jewish man named Tărnăuceanu, was denounced by a priest to the Romanian authorities in the northern Bukovinian town of Noua Suliță. The priest alleged that during the Soviet occupation Tărnăuceanu had identified the priest's vehicle for the Russian authorities, who then requisitioned it. The priest's denunciation led to Tărnăuceanu's arrest and his execution the next day together with a group of approximately 30 Communist suspects (USHMM, RG-25.004M Selected Records, Reel 23, File 20521, 122).

79 USHMM, RG-31.006M Czernowitz Oblast, Reel 22, File 576, 323.

80 United States Holocaust Memorial Museum, RG-54.001 Selected Records from the Moldova National Archives: Chișinău, Reel 7, File 6586, 330.

81 USHMM, RG-31.006M Czernowitz Oblast, Reel 15, File 95, 37.

82 USHMM, RG-31.006M Czernowitz Oblast, Reel 15, File 95, 37-38.

83 Gellately argued convincingly that in Nazi Germany citizens were not only expected to adjust themselves to the new system but also to become idealistically driven and reflect back to the country's leaders the centrality of the values for which they stood. Many Germans cooperated with the authorities not in a blind fashion but because they convinced themselves of the advantages and benefits made available to them by the new dictatorship. See Gellately, Backing Hitler, 257.

84 USHMM, RG-54.001 Selected Records, Reel 7, File 6586, 558-559.

85 USHMM, RG-54.001 Selected Records, Reel 7, File 6590, 896. 
86 USHMM, RG-25.003M Selected Records, Reel 128, File 96, 167.

87 USHMM, RG-25.003M Selected Records, Reel 128, File 96, 167-169.

88 See, for instance, in the Introduction of the book, the thank-you note in which the government of Bessarabia formally recognized Chișinău resident Maria Vasiliu's merits for participating in the capture of the Jews Clara and Marcel Schwartzberg (USHMM, RG-25.003M Selected Records, Reel 131, File 32, 65).

89 USHMM, RG-31.006M Czernowitz Oblast, Reel 22, File 329, 24-25.

90 USHMM, RG-31.006M Czernowitz Oblast, Reel 22, File 329, 23.

91 USHMM, RG-31.006M Czernowitz Oblast, Reel 23, File 18, 16.

92 USHMM, RG-31.006M Czernowitz Oblast, Reel 37, File 236, 8-9.

93 USHMM, RG-31.006M Czernowitz Oblast, Reel 37, File 236, 9.

94 USHMM, RG-31.006M Czernowitz Oblast, Reel 37, File 236, 10-12.

95 In his petition Popescu mentioned that despite the National Center for Romanianization granting him and the administrator of the Z.I.180 hospital the authorization to produce 500 beds for the hospital from the furniture left behind by the Jewish deportees, they were obstructed by the local resident Eugen Forgaci who claimed he had power of attorney from the deportees in the Moghilev camp to protect their belongings. Popescu also described the dispute he had with a Christian local over Antler's property when the latter claimed to have inherited it from Moritz Antler's wife (USHMM, RG-31.006M Czernowitz Oblast, Reel 37, File 236, 8-9).

96 Vági, Csősz \& Kádár (eds.), The Holocaust in Hungary, 282.

97 Tönsmeyer, "The Robbery of Jewish Property," 85.

98 USHMM, Fichman, Before Memories Fade, 82-83.

99 The Jews in Romania were not the only ones to be suspected of anti-patriotic activities. An abundance of Hungarian police reports from 1941 described the confiscation of radios from Jews who were thought to be listening to "enemy broadcast stations." See Maria Schmidt, "Provincial Police Reports - New Insights into Hungarian Jewish History, 1941-1944" in Yad Vashem Studies 19 (1988), 240.

100 USHMM, RG-25.003M Selected Records, Reel 27, File 6627, 407.

101 USHMM, RG-25.003M Selected Records, Reel 27, File 6627, 393.

102 USHMM, RG-25.003M Selected Records, Reel 127, File 177, 38. The local population was aware of the power granted to various civilian authorities over the Romanianization of the economy. Acting on tip-offs it received from local sources, the Directorate for the National Economy in Cernăuți reported to the regional government in March 1943 the existence of a camouflaged Jewish business in the city. The business had been investigated before but had managed to remain operational. The Romanian owner, Ion Croitoru, was suspected of hiring Jewish employees. One of them, Pincas Weismann, had authorization to travel outside the region, which allowed him to conduct business in Bessarabia on Croitoru's behalf. The Romanian authorities assumed that in reality the Jewish workers were running Croitoru's business (USHMM, RG-31.006M Czernowitz Oblast, Reel 35, File 73, 697).

103 USHMM, RG-25.003M Selected Records, Reel 127, File 177, 39.

104 USHMM, RG-25.003M Selected Records, Reel 127, File 177, 38. Vera Cara provided a separate statement to the authorities in which she confirmed Nicolae Mironescu's accounts (USHMM, RG-25.003M Selected Records, Reel 127, File 177, 41).

105 USHMM, RG-25.003M Selected Records, Reel 127, File 177, 38.

106 The account is provided in both Nicolae Mironescu and Vera Cara's testimonies (USHMM, RG-25.003M Selected Records, Reel 127, File 177, 38-41).

107 USHMM, RG-31.006M Czernowitz Oblast, Reel 22, File 38, 692.

108 USHMM, RG-31.006M Czernowitz Oblast, Reel 22, File 38, 692.

109 Since before Operation Barbarossa the Romanian Security police in Bukovina had assumed that Jews were collaborating with the Communists. Their suspicion was in 
part grounded in the fact that Jewish photographers had received instructions from the Soviets to clandestinely photograph certain people. See Angrick, "Power Games," 98.

110 Scholars have provided compelling evidence that there is a correlation between the intention or wish to exterminate an entire people and a society based on individual greed, competitiveness, political domination, the alienation of human labor and the commodification of human beings and their rapports. See Sabby Sagall Final Solutions: Human Nature, Capitalism and Genocide (London: Pluto Press, 2013), 248.

111 See Diana Dumitru, State, Antisemitism and Collaboration in the Holocaust: The Borderlands of Romania and the Soviet Union (New York: Cambridge University Press, 2016), 167.

112 Holocaust historian Nechama Tec analyzed the motivation of rescuers who acted under Nazi occupation and concluded that only 16 percent were animated by financial incentives. See Nechama Tec, "Who Dared to Rescue Jews, and Why?" in Resisting Genocide: The Multiple Forms of Rescue, eds. Jacques Andrieu Claire Semelin and Sarah Gensburger (New York: Columbia University Press, 2014), 106.

113 Hoffer, L. (1995). Interview 945. Tape 2. 5:30-6:38. Visual History Archives, USC Shoah Foundation. Retrieved May 10, 2016.

114 Friling, Ioanid, Ionescu (eds.), Final Report, 307.

115 Deletant, Hitler's Forgotten Ally, 156-157.

116 Ibid., 161-165.

117 Yad Vashem, The Collection of the Righteous Among the Nations, File M.31.2/10658.

118 Yad Vashem, The Collection of the Righteous Among the Nations, File M.31.2/10818.

119 Yad Vashem, The Collection of the Righteous Among the Nations, File M.31.2/725.

120 Marius Mircu, Din nou șapte momente - din istoria evreilor din România: Oameni de omenie în vremuri de neomenie (Tel Aviv: Glob, 1987), 87.

121 Yad Vashem, The Collection of the Righteous Among the Nations, File M.31.2/4779.

122 Yad Vashem, The Collection of the Righteous Among the Nations, File M.31.2/10358.

123 The military authorities' murderous campaign against the Bessarabian Jews benefited from the support provided by a network of informers who reported on the local population during the year of Soviet occupation, as well as the readiness of local volunteers who facilitated the identification, arrest and murder of Jews during the re-annexation. See Friling, Ioanid, Ionescu (eds.), Final Report, 132.

124 Dumitru, The State, Antisemitism and Collaboration, 166-168.

125 Yad Vashem, The Collection of the Righteous Among the Nations, M.31.2/7338.

126 Yad Vashem, The Collection of the Righteous Among the Nations, M.31.2/10180.

127 Yad Vashem, The Collection of the Righteous Among the Nations, M.31.2/9669.

128 Yad Vashem, The Collection of the Righteous Among the Nations, M.31.2/10108.

129 USHMM, RG-25.004M Selected Records, Reel 16, File 22539, 199.

130 Yad Vashem, The Collection of the Righteous Among the Nations, M.31.2/6084.

131 USHMM, RG-25.003M Selected Records, Reel 657, File 32, 22, 48.

132 Yad Vashem, The Collection of the Righteous Among the Nations, M.31.2/10023.

133 Tec, "Researching the Survival and Rescue," 105.

134 Bar-On, "The Bystander in Relation to the Victim and the Perpetrator," 132.

135 Ethan J. Hollander, "The Final Solution in Bulgaria and Romania: A Comparative Perspective" in East European Politics and Societies Vol. 22, No. 2 (2008), 222.

136 Sullam, The Italian Executioners, 93.

137 Kristen Renwick Monroe, "Cracking the Code of Genocide," 700. 


\section{References}

\section{Introduction}

Achim, Viorel. "Deportarea evreilor în Transnistria în contextual politicii demografice a guvernului Antonescu." In Holocaustul la Periferie: Persecutarea și nimicirea evreilor în România şi Transnistria în 1940-1944, edited by Wolfgang Benz and Brigitte Mihok, 233-249. Chişinău: Cartier, 2010.

Ancel, Jean (ed.). Documents Concerning the Fate of the Romanian Jewry during the Holocaust Vol. 5 Bessarabia, Bukovina, Transnistria: Extermination and Survival. New York: Beate Klarsfeld Foundation, 1986.

Ancel, Jean. "The Image of the Jew in the View of the Romanian Anti-Semitic Movements: Continuity and Change." Shvut: Jewish Problems in Eastern Europe Vol. 16 (1993), 39-57.

Ancel, Jean (ed.). Wilhelm Filderman: Memoirs and Diaries Vol. 1, 1900-1940. Jerusalem: Tel Aviv University and Yad Vashem, 2004.

Ancel, Jean. The History of the Holocaust in Romania. Lincoln, NE and Jerusalem: University of Nebraska Press and Yad Vashem, 2011.

Anderson, Benedict. Imagined Communities: Reflections on the Origin and Spread of Nationalism. London and New York: Verso, 2006.

Barnett, Victoria. Bystanders. Conscience and Complicity During the Holocaust. Westport, CT and London: Praeger, 1999.

Benz, Wolfgang. "România și holocaustul.” In Holocaustul la Periferie: Persecutarea și nimicirea evreilor în România și Transnistria în 1940-1944, edited by Wolfgang Benz and Brigitte Mihok, 13-45. Chișinău: Cartier, 2010.

Braham, Randolph L. The Politics of Genocide: The Holocaust in Hungary. Detroit: Wayne State University Press, 2000.

Brustein, William and Ronnkvist, Amy. "The Roots of Anti-Semitism: Romania before The Holocaust." Journal of Genocide Research Vol. 4, No. 2 (June 2002), 211-235.

Burrin, Philippe. France under the Germans. Collaboration and Compromise. New York: The New Press, 1997.

Charny, Israel W. The Genocide Contagion: How We Commit and Confront Holocaust and Genocide. Lanham, Boulder, CO, New York and London: Rowman \& Littlefield, 2016.

Clark, Roland. Holy Legionary Youth: Fascist Activism in Interwar Romania. Ithaca, NY and London: Cornell University Press, 2015.

Dean, Martin. Collaboration in the Holocaust: Crimes of the Local Police in Belorussia and Ukraine, 1941-1944. New York: St. Martin's Press, 2000. 
Deletant, Dennis. Hitler's Forgotten Ally. Ion Antonescu and His Regime, Romania 19401944. London and New York: Palgrave Macmillan, 2006.

Dumitru, Diana. "Through the Eyes of the Survivors: Jewish-Gentile Relations in Bessarabia and Transnistria during the Holocaust." In Eradicating Differences: The Treatment of Minorities in Nazi-Dominated Europe, edited by Anton Weiss-Wendt, 203-227. Newcastle upon Tyne: Cambridge Scholars, 2010.

Dumitru, Diana. "Peasants' Perceptions of Jewish Life in Interwar Bessarabia and How this became Interwoven into the Holocaust." Plural Vol. I, No. 1-2 (2013), 131-148.

Dumitru, Diana. The State, Antisemitism and Collaboration in the Holocaust: The Borderlands of Romania and the Soviet Union. New York: Cambridge University Press, 2016.

Dundes, Alan. From Game to War, and Other Psychoanalytic Essays on Folklore. Lexington, KY: University Press of Kentucky, 1997.

Eaton, Henry. The Origins and Onset of the Romanian Holocaust. Detroit, MI: Wayne State University Press, 2013.

Elster, Jon. "Redemption for Wrongdoing. The Fate of Collaborators after 1945." Journal of Conflict Resolution Vol. 50, No. 3 (June 2006), 324-338.

Enescu, C. "Semnificația Alegerilor din Decemvrie 1937 în evoluția politică a neamului românesc." Sociologie Românească Vol. II, No. 11-12 (November-December 1937), 512-526.

Finder, Gabriel and Prusin, Alexander. "Collaboration in Eastern Galicia: The Ukrainian Police and the Holocaust." Eastern European Jewish Affairs Vol. 34, No. 2 (2004), 95-118.

Friling, Tuvia, Ioanid Radu and Ionescu Mihail E. (eds.). Final Report of the International Commission on the Holocaust in Romania. Iași: Polirom, 2005.

Frydel, Tomasz. "Judenjagd: Reassessing the Role of Ordinary Poles as Perpetrators in the Holocaust." In Perpetrators and Perpetration of Mass Violence, Action, Motivations and Dynamics, edited by Timothy Williams and Susanne Buckley-Zistel, 187-203. New York: Routledge, 2018.

Geissbühler, Simon. “'He Spoke Yiddish Like a Jew': Neighbors' Contribution to the Mass Killing of Jews in Northern Bukovina and Bessarabia, July 1941." Holocaust and Genocide Studies Vol. 28, No. 3 (Winter 2014), 430-449.

Geissbühler, Simon. Iulie Însângerat. România și Holocaustul din vara lui 1941. Bucharest: Curtea Veche, 2015.

Goldstein, Ivo and Goldstein, Slavko. The Holocaust in Croatia. Pittsburgh: University of Pittsburgh Press, 2016.

Gordon, Bertram M. "The Morphology of the Collaborator: The French Case." Journal of European Studies Vol. 23, No. 1 (March 1993), 1-25.

Gross, Jan Tomasz. Polish Society under German Occupation: The Generalgouvernment, 1939-1944. Princeton, NJ: Princeton University Press, 1979.

Hausleitner, Mariana. "Jewish Communist Gangs in Czernowitz?" In Romania and the Holocaust, edited by Simon Geissbühler, 17-40. Stuttgart: Ibidem, 2016.

Haynes, Rebecca Ann. "Germany and the Establishment of the Romanian National Legionary State, September 1940." The Slavonic and East European Review Vol. 77, No. 4 (October 1999), 700-725.

Haynes, Rebecca Ann. "Reluctant Allies? Iuliu Maniu and Corneliu Zelea Codreanu against King Carol II of Romania." The Slavonic and East European Review Vol. 85, No. 1 (January 2007), 105-134.

Heinen, Armin. România, Holocaustul şi Logica Violenței. Iași: Editura Universității "Alexandru Ioan Cuza," 2011. 
Hilberg, Raul. Perpetrators, Victims, Bystanders: The Jewish Catastrophe 1933-1945. New York: HarperCollins, 1992.

Ioanid, Radu. The Sword of the Archangel: Fascist Ideology in Romania. Boulder, CO: East European Monographs, 1990.

Ioanid, Radu. The Holocaust in Romania: The Destruction of Jews and Gypsies under the Antonescu Regime, 1940-1944. Chicago: Ivan R Dee, 2000.

Kershaw, Ian. Hitler, the Germans and the Final Solution. New Haven, CT and London: Yale University Press, 2008.

Livezeanu, Irina. Cultural Politics in Greater Romania: Regionalism, Nation Building and Ethnic Struggle, 1918-1930. Ithaca, NY and London: Cornell University Press, 1995.

Longerich, Peter. Holocaust: The Nazi Persecution and Murder of the Jews. New York: Oxford University Press, 2010.

Lower, Wendy. Nazi Empire-building and the Holocaust in Ukraine. Chapel Hill: The University of North Carolina Press, 2005.

Markusen, Eric. "Mechanisms of Genocide." In Will Genocide Ever End? edited by Carol Rittner, John K. Roth, and James M. Smith, 83-89. St. Paul, MN: Paragon House, 2002.

Mendelsohn, Ezra. The Jews of East Central Europe between the World Wars. Bloomington, IN: Indiana University Press, 1983.

Monroe, Renwick Kristen. "Cracking the Code of Genocide: The Moral Psychology of Rescuers, Bystanders and Nazis during the Holocaust." Political Psychology Vol. 29, No. 5 (2008), 699-736.

Ofer, Dalia. "Emigration and Immigration: The Changing Role of Romanian Jewry." In The Destruction of Romanian and Ukrainian Jews During the Antonescu Era, edited by Randolph L. Braham, 19-43. Boulder, CO: Social Science Monographs, 1997.

Oișteanu, Andrei. Inventing the Jew: Antisemitic Stereotypes in Romanian and Other Central-East European Cultures. Lincoln, NE and London: University of Nebraska Press, 2009.

Oldson, William. A Providential Anti-Semitism. Nationalism and Polity in Nineteenth Century Romania. Philadelphia: The American Philosophical Society, 1991.

Ornea, Zigu. Anii treizeci: Extrema dreaptă românească. Bucharest: Cartea Românească, 2015.

Pippidi, Andrei. "The Mirror and Behind It: The Image of the Jew in the Romanian Society." Shvut: Jewish Problems in Eastern Europe Vol. 16, (1993), 73-83.

Prusin, Alexander. Serbia under the Swastika: A World War II Occupation. Urbana, IL, Chicago, and Springfield, IL: University of Illinois Press, 2017.

Rein, Leonid. The Kings and the Pawns. Collaboration in Byelorussia during World War II. New York: Berghahn, 2011.

Semelin, Jacques. Purify and Destroy: The Political Uses of Massacre and Genocide. New York: Columbia University Press, 2007.

Shapiro, Paul A. "Prelude to Dictatorship in Romania: The National Christian Party in Power December 1937-February 1938." Canadian-American Slavic Studies Vol. VIII, No. 1 (Spring 1974), 45-88.

Solonari, Vladimir. "Patterns of Violence: The Local Population and the Mass Murder of Jews in Bessarabia and Northern Bukovina. July-August 1941." Kritika: Explorations in Russian and Eurasian History Vol. 8, No. 4 (2007), 749-787.

Solonari, Vladimir. Purifying the Nation: Population Exchange and Ethnic Cleansing in Nazi-Allied Romania. Washington, DC and Baltimore, MD: Woodrow Wilson Center Press and Johns Hopkins University Press, 2010. 
Someșan, Maria. "Mișcarea Studențească din 1922.” Anuarul Institutului Român de Istorie Recentă Vol. 1, (2002), 175-206.

Sullam, Simon Levis. The Italian Executioners: The Genocide of the Jews of Italy. Princeton, NJ: Princeton University Press, 2018.

United States Holocaust Memorial Museum, RG-25.003M, Selected Records from the Romanian Ministry of Defense 1940-1945, File 32, Reel 131, 65.

Volovici, Leon. National Ideology and Antisemitism: The Case of Romanian Intellectuals in the 1930s. New York: Pergamon Press, 1991.

Yeomans, Rory. Visions of Annihilation: The Ustasha Regime and the Cultural Politics of Fascism 1941-1945. Pittsburgh: University of Pittsburgh Press, 2013.

\section{Chapter 1}

Ancel, Jean (ed.). Documents Concerning the Fate of the Romanian Jewry during the Holocaust Vol. 5 Bessarabia, Bukovina, Transnistria: Extermination and Survival. New York: Beate Klarsfeld Foundation, 1986.

Ancel, Jean. The Economic Destruction of Romanian Jewry. Jerusalem: Yad Vashem, 2007. Ancel, Jean. The History of the Holocaust in Romania. Lincoln, NE and Jerusalem: University of Nebraska Press and Yad Vashem, 2011.

Ancel, Jean and Lavi, Théodor (eds.). Pinkas HaKehilot Romania (Encyclopedia of Jewish Communities: Romania), Vol. II. Jerusalem: Yad Vashem, 1980.

Benjamin, Lya (ed.). Evreii din România între anii 1940-1944 Vol. II Problema Evreiască in Stenogramele Consiliului de Miniștri. Bucharest: Hasefer, 1996.

Benjamin, Lya (ed.). Comisia Internațională pentru Studierea Holocaustului în România, Documente. Iași: Polirom, 2005.

Dean, Martin. Collaboration in the Holocaust: Crimes of the Local Police in Belorussia and Ukraine, 1941-1944. New York: St. Martin's Press, 2000.

Deletant, Dennis. Hitler's Forgotten Ally. Ion Antonescu and His Regime, Romania 19401944. London and New York: Palgrave Macmillan, 2006.

Dumitru, Diana. "Attitudes towards Jews in Odessa: From Soviet Rule Through Romanian Occupation 1921-1944." Cahiers du Monde Russe Vol. 52, No. 1 (2011), 133-162.

Dumitru, Diana. State, Antisemitism and Collaboration in the Holocaust: The Borderlands of Romania and the Soviet Union. New York: Cambridge University Press, 2016.

Dumitru, Diana and Johnson, Carter. "Constructing Interethnic Conflict and Cooperation. Why Some People Helped Jews and Others Harmed Them during the Holocaust in Romania." World Politics Vol. 63, No. 1 (January 2011), 1-42.

Eberhardt, Piotr. Ethnic Groups and Population Changes in Twentieth-Century CentralEastern Europe, History, Data and Analysis. Armonk, NY and London: M.E. Sharpe, 2003.

Fichman, Pearl. Before Memories Fade. United States Holocaust Memorial Museum Archives, Accession Number: 1994.A.0058.

Friling, Tuvia, Ioanid Radu, and Ionescu Mihail E. (eds.) Final Report of the International Commission on the Holocaust in Romania. Iași: Polirom, 2005.

Fromm, Erich. The Anatomy of Human Destructiveness. London: Jonathan Cape, 1974.

Geissbühler, Simon. "The Rape of Jewish Women and Girls during the First Phase of the Romanian Offensive in the East, July 1941: A Research Agenda and Preliminary Findings." Holocaust Studies Vol. 19, No. 1 (Summer 2013), 59-80. 
Geissbühler, Simon. “"He Spoke Yiddish Like a Jew”: Neighbors Contribution to the Mass Killing of Jews in Northern Bukovina and Bessarabia, July 1941." Holocaust and Genocide Studies Vol. 28, No. 3 (Winter 2014), 430-449.

Gerlach, Christian. "Extremely Violent Societies: An Alternative to the Concept of Genocide." Journal of Genocide Research Vol. 8, No. 4 (2006), 455-471.

Gilbert, Martin. The Routledge Atlas of the Holocaust, 4th edition. New York: Routledge, 2009.

Gross, Jan Tomasz. Revolution from Abroad: The Soviet Conquest of Poland's Western Ukraine and Western Belorussia. Princeton: Princeton University Press, 1988.

Gurr, Ted Robert. Why Men Rebel. Princeton, NJ: Princeton University Press, 1970.

Hausleitner, Mariana. "Evreii și Antisemitismul în Bucovina între 1918 şi 1944." In Studia et Acta Historiae Iudeorum Romaniae, Vol. VIII, edited by Dumitru Vitcu and Sivliu Sanie, 195-213. Bucharest: Hasefer, 2003.

Headland, Ronald. Messages of Murder: A Study of the Reports of the Einsatzgruppen of the Security Police and the Security Service, 1941-1943. Teaneck, NJ: Fairleigh Dickinson University Press, 1992.

Heinen, Armin. România, Holocaustul și Logica Violenței. Iași: Editura Universității "Alexandru Ioan Cuza," 2011.

Himka, John-Paul. "Western Ukraine between the Wars." Canadian Slavonic Papers/ Revue Canadienne de Slavistes Vol. 34, No. 4 (December 1992), 391-412.

Ioanid, Radu. The Holocaust in Romania: The Destruction of Jews and Gypsies under the Antonescu Regime, 1940-1944. Chicago: Ivan R Dee, 2000.

Lickel, Brian. "Retribution and Revenge." In The Oxford Handbook of Intergroup Conflict, edited by Linda R. Tropp, 89-105. New York: Oxford University Press, 2012.

Livezeanu, Irina. Cultural Politics in Greater Romania: Regionalism, Nation Building and Ethnic Struggle, 1918-1930. Ithaca, NY and London: Cornell University Press, 1995.

Mann, Michael. The Dark Side of Democracy: Explaining Ethnic Cleansing. New York: Cambridge University Press, 2005.

Petersen, Roger. Understanding Ethnic Violence, Fear, Hatred and Resentment in Twentieth Century Eastern Europe. Cambridge: Cambridge University Press, 2002.

Popescu, Ion and Ungureanu, Constantin. Românii din Ucraina între trecut și viitor. Românii din regiunea Cernăuți. Oradea, Romania: Primus, 2010.

Reifer, Manfred. "History of the Jews in the Bukowina (1919-1944)." In Geschichte der Juden in der Bukowina ((History of the Jews in the Bukowina), Vol. II, edited by Hugo Gold, 1-27. Tel Aviv: Olamenu, 1962.

Reifer, Manfred. "Istoria Evreilor din Bucovina după Ocupația Austriacă." In Evreii din România în Texte Istoriografice, edited by Lya Benjamin, 545-553. Bucharest: Hasefer, 2002.

Rodal, Alti. "A Village Massacre: The Particular and the Context." In Romania and the Holocaust, edited by Simon Geissbühler, 59-88. Stuttgart: Ibidem, 2016.

Rones, Loniu. A Survivor of Cariera de Piatră: A Memoir. United States Holocaust Memorial Museum Archives, Accession Number: 1996.A.0406.

Rossino, Alexander B. "Polish "Neighbors" and German Invaders: Contextualizing AntiJewish Violence in the Białystok District during the Opening Weeks of Operation Barbarossa." Studies in Polish Jewry Vol. 16, (2003), 431-452.

Segal, Raz. Genocide in the Carpathians, War, Social Breakdown and Mass Violence 1914-1945. Stanford: Stanford University Press, 2016.

Seidmann, S. J. "Kotzman." In Geschichte der Juden in der Bukowina (The History of the Jews in Bukovina), Vol. II, edited by Hugo Gold, 90-91. Tel Aviv: Olamenu, 1962. 
Shapiro, Paul A. "Prelude to Dictatorship in Romania: The National Christian Party in Power December 1937-February 1938." Canadian-American Slavic Studies Vol. VIII, No 1 (Spring 1974), 45-88.

Solonari, Vladimir. "Patterns of Violence: The Local Population and the Mass Murder of Jews in Bessarabia and Northern Bukovina. July-August 1941." Kritika: Explorations in Russian and Eurasian History Vol. 8, No. 4 (2007), 749-787.

Solonari, Vladimir. Purifying the Nation: Population Exchange and Ethnic Cleansing in Nazi-Allied Romania. Washington, DC and Baltimore: Woodrow Wilson Center Press and Johns Hopkins University Press, 2010a.

Solonari, Vladimir. "The Treatment of the Jews of Bukovina by the Soviet and Romanian Administrations in 1940-1944." Holocaust and Modernity Vol. 2, No. 8 (2010b), 149-180.

Spector, Shmuel and Wigoder, Geoffrey (eds.). The Encyclopedia of Jewish Life: Before and during the Holocaust. New York: New York University Press, 2001.

Staub, Ervin. The Roots of Evil: The Origins of Genocide and Other Group Violence. New York: Cambridge University Press, 1989.

Staub, Ervin. The Psychology of Good and Evil: Why Children, Adults, and Groups Help and Harm Others. New York: Cambridge, 2003.

Struve, Kai. “Anti-Jewish Violence in the Summer of 1941.” In Romania and the Holocaust, edited by Simon Geissbühler, 89-113. Stuttgart: Ibidem, 2016.

Tartakovsky, Dmitry. Parallel Ruptures: Jews of Bessarabia and Transnistria Between Romanian Nationalism and Soviet Communism, 1918-1940. Proquest, Umi Dissertation Publishing, 2011.

Ungureanu, Constantin. Bucovina în perioada stăpânirii austriece (1775-1918). Chișinău: Civitas, 2003.

United States Holocaust Memorial Museum, RG-25.004M, Selected Records from the Romanian Information Service 1936-1948Reel 15 File 1241, Reel 16 File 22539, Reel 23 File 20521, Reel 28 File 37818, Reel 151 Vol.3 File 40021.

United States Holocaust Memorial Museum, RG-54.003, War Crimes Investigation and Trial Records from the Republic of Moldova 1944-1955, Acc.2004.691, File 28002, File 20855, File 28581, File 18143 Vol.2, File 20867, File 20849, File 5360.

United States Holocaust Memorial Museum's, Moldova Documentation Project 2008 RG-50.572*0115 David Popa, Tape 1, RG-50.572*0123 Elena Bufteac, Tape 1, RG-50.572*0117 Silvestru Băt, Tape 1 .

United States Holocaust Memorial Museum's, Romania Documentation Project RG. $50.573 * 0016$ Gleb Ciudacov.

University of Southern California Shoah Foundation Institute, Visual History Archives Koller, M. (1997). Interview 30622 Tape 2.

Waldman, Asriel. The Fine Line. United States Holocaust Memorial Museum Archives, Accession Number: 2011.357.1.

Welzer, Harald. "On Killing and Morality: How Normal People Become Mass Murderers." In Ordinary People as Mass Murderers: Perpetrators in Comparative Perspectives, edited by Olaf Jensen and Claus Christian W. Sznejnmann, 165-181. London and New York: Palgrave Macmillan, 2008.

Wood, Elisabeth Jean. "Armed Groups and Sexual Violence: When Is Wartime Rape Rare.” Politics Society Vol. 37, No. 131 (2009), 131-161. 


\section{Chapter 2}

Ancel, Jean. The History of the Holocaust in Romania. Lincoln and Jerusalem: University of Nebraska Press and Yad Vashem, 2011.

Ancel, Jean and Lavi, Théodor (eds.). Pinkas HaKehilot Romania (Encyclopedia of Jewish Communities: Romania), Vol. I. Jerusalem: Yad Vashem, 1969.

Bar-On, Dan. "The Bystander in Relation to the Victim and the Perpetrator: Today and During the Holocaust." Social Justice Research Vol. 14, No. 2 (June 2001), 125-148.

Browning, Christopher R. "Before the "Final Solution": Nazi Ghettoization Policy in Poland (1940-1941)." In Ghettos 1939-1945 New Research and Perspectives on Definition, Daily Life and Survival Symposium Presentations. Washington, DC: Center for Advanced Holocaust Studies United States Holocaust Memorial Museum, 2005, 1-13.

Ciucă, Marcel-Dumitru and Ignat, Maria (eds.). Stenogramele Ședințelor Consiliului de Miniștri. Guvernarea Ion Antonescu. Vol. V, Octombrie 1941, Ianuarie 1942. Bucharest: Arhivele Naționale ale României, 2001.

Deletant, Dennis. "Aspects of the Ghetto Experience in Eastern Transnistria: The Ghettos and Labor Camp in the Town of Golta." Ghettos 1939-1945 New Research and Perspectives on Definition, Daily Life and Survival Symposium Presentations. Washington, DC: Center for Advanced Holocaust Studies United States Holocaust Memorial Museum, 2005, 15-66.

Deletant, Dennis. Hitler's Forgotten Ally. Ion Antonescu and His Regime, Romania 19401944. London and New York: Palgrave Macmillan, 2006.

Dumitru, Diana. "Peasants' Perceptions of Jewish Life in Interwar Bessarabia and How This became Interwoven into the Holocaust." Plural Vol. I, 1-2 (2013), 131-148.

Dumitru, Diana. State, Antisemitism and Collaboration in the Holocaust: The Borderlands of Romania and the Soviet Union. New York: Cambridge University Press, 2016.

Grilj, Benjamin (ed.). Schwarze Milch: Zurückgehaltene Briefe aus den Todeslagern Transnistriens, 1st edition. Innsbruck: Studien Verlag, German/English/Romanian/ Ukrainian, 2013.

Hilberg, Raul. The Destruction of the European Jews, Vol. II. New Haven and London: Yale University Press, 2003.

Kahana-Aufleger, Lotti. Survival. United States Holocaust Memorial Museum, DS135. U43 K246 1990.

Segal, Raz. Genocide in the Carpathians, War, Social Breakdown and Mass Violence 1914-1945. Stanford: Stanford University Press, 2016.

Shachan, Avigdor. Burning Ice. The Ghettos of Transnistria. Boulder, CO: Eastern European Monographs, 1996.

Shapiro, Paul A. "Prelude to Dictatorship in Romania: The National Christian Party in Power December 1937-February 1938." Canadian-American Slavic Studies Vol. VIII, No. 1 (Spring 1974), 45-88.

Shapiro, Paul A. The Kishinev Ghetto 1941-1942, A Documentary History of the Holocaust in Romania's Contested Borderlands. Tuscaloosa: The University of Alabama Press, 2015.

Skolnik, Fred (ed.). Encyclopedia Judaica, 2nd edition. Jerusalem: The Jerusalem Publishing House/Thomson Gale, 2007.

Staub, Ervin. The Roots of Evil: The Origins of Genocide and Other Group Violence. New York: Cambridge University Press, 1989.

Staub, Ervin. Overcoming Evil. Genocide, Violent Conflict and Terrorism. New York: Oxford University Press, 2011. 
Sullam, Simon Levis. The Italian Executioners: The Genocide of the Jews of Italy. Princeton, NJ: Princeton University Press, 2018.

United States Holocaust Memorial Museum, RG-54.001M, Selected Records from the Moldova National Archives: Chişinău, Reel 128 File 6586.

United States Holocaust Memorial Museum, RG-25.004M, Selected Records from the Romanian Information Service 1936-1948, Reel 19 File 40011, Reel 23 File 20521, Reel 23 File 40011, Reel 24 File 22725, Reel 25 File 20725, Reel 28 File 40013, Reel 29 File 40013, Reel 65 File 181, Reel 128 File 96, Reel 131 File 32, Reel 150 File 40011, Reel 150 File 40021.

United States Holocaust Memorial Museum, RG-54.003 War Crimes Investigations and Trial Records from the Republic of Moldova 1944-1955 Acc.2004.691 File 020970, File 18530.

United States Holocaust Memorial Museum, RG-25.003M, Selected Records from the Romanian Ministry of Defense 1940-1945, Reel 128 File 96, Reel 131 File 32.

\section{Chapter 3}

Ancel, Jean (ed.). Wilhelm Filderman: Memoirs and Diaries Vol. 1, 1900-1940. Jerusalem: Tel Aviv University and Yad Vashem, 2004.

Ancel, Jean. The Economic Destruction of Romanian Jewry. Jerusalem: Yad Vashem, 2007.

Angrick, Andrej. "Power Games: The German Nationality Policy (Volkstumspolitik) in Czernowitz before and during the Barbarossa Campaign." Dapim: Studies on the Holocaust Vol. 24 (2010), 89-135.

Benjamin, Lya (ed.). Evreii din România între anii 1940-1944 Vol. II Problema Evreiască in Stenogramele Consiliului de Miniștri. Bucharest: Hasefer, 1996.

Ceaușu, Mihai-Ștefan. "Structura Economico-Socială a Populației Evreiești din Bucovina (1848-1914)." In Studia et Acta Historiae Iudeorum Romaniae, Vol. VI, edited by Dumitru Vitcu and Sivliu Sanie, 188-200. Bucharest: Hasefer, 2001.

Clark, Roland. "Claiming Ethnic Privilege: Aromanian Immigrants and Romanian Fascist Politics." Contemporary European History Vol. 24, No. 1 (February 2015), 37-58.

Deletant, Dennis. Hitler's Forgotten Ally. Ion Antonescu and His Regime, Romania 19401944. London and New York: Palgrave Macmillan, 2006.

Dumitru, Diana. State, Antisemitism and Collaboration in the Holocaust: The Borderlands of Romania and the Soviet Union. New York: Cambridge University Press, 2016.

Friling, Tuvia, Ioanid Radu and Ionescu Mihail E. (eds.). Final Report of the International Commission on the Holocaust in Romania. Iași: Polirom, 2005.

Gellately, Robert. "Denunciations in XX Century Germany: Aspects of Self-Policing in the Third Reich and The German Democrat Republic." The Journal of Modern History Vol. 68, (December 1996), 931-967.

Gellately, Robert. Backing Hitler: Consent and Coercion in Nazi Germany. New York: Oxford University Press, 2001.

Hausleitner, Mariana. "Jewish Communist Gangs in Czernowitz?" In Romania and the Holocaust, edited by Simon Geissbühler, 17-40. Stuttgart: Ibidem, 2016.

Heinen, Armin. România, Holocaustul și Logica Violenței. Iași: Editura Universității "Alexandru Ioan Cuza," 2011.

Hollander, Ethan J. "The Final Solution in Bulgaria and Romania: A Comparative Perspective." East European Politics and Societies Vol. 22, No. 2 (2008), 203-248. 
Ioanid, Radu. The Holocaust in Romania: The Destruction of Jews and Gypsies Under the Antonescu Regime, 1940-1944. Chicago: Ivan R Dee, 2000.

Ionescu, Cristian Ștefan. Jewish Resistance to "Romanianization”, 1940-1944. London and New York: Palgrave Macmillan, 2015.

Kühne, Thomas. Belonging and Genocide, Hitler's Community 1918-1945. New Haven and London: Yale University Press, 2010.

Levene, Mark. Genocide in the Age of the Nation State, Vol. 1, The Meaning of Genocide. New York: I. B. Tauris, 2005.

Mircu, Marius. Din nou șapte momente - din istoria evreilor din România: Oameni de omenie în vremuri de neomenie. Tel Aviv: Glob, 1987.

Sagall, Sabby. Final Solutions: Human Nature, Capitalism and Genocide. London: Pluto Press, 2013.

Schmidt, Maria. "Provincial Police Reports - New Insights into Hungarian Jewish History, 1941-1944." Yad Vashem Studies Vol. 19 (1988), 233-267.

Sebastian, Mihail. Jurnal 1935-1944. București: Humanitas, 1996.

Solonari, Vladimir. Purifying the Nation: Population Exchange and Ethnic Cleansing in Nazi-Allied Romania. Washington, DC and Baltimore: Woodrow Wilson Center Press and Johns Hopkins University Press, 2010a.

Solonari, Vladimir. "The Treatment of the Jews of Bukovina by the Soviet and Romanian Administrations in 1940-1944." Holocaust and Modernity Vol. 2, No. 8 (2010b), 149-180.

Smith, David Norman. "The Social Construction of Enemies: Jews and the Representation of Evil.” Sociological Theory Vol. 14, No. 3 (November 1996), 203-240.

Sullam, Simon Levis. The Italian Executioners: The Genocide of the Jews of Italy. Princeton, NJ: Princeton University Press, 2018.

Tec, Nechama. "Who Dared to Rescue Jews, and Why?" In Resisting Genocide: The Multiple Forms of Rescue, edited by Jacques Andrieu Claire Semelin and Sarah Gensburger, 101-112. New York: Columbia University Press, 2014.

Tönsmeyer, Tatjana. "The Robbery of Jewish Property in Eastern Europe States Allied with Nazi Germany." In Robbery and Restitution: The Conflict over Jewish Property in Europe, edited by Martin Dean, Constantin Goschler, and Philipp Ther, 81-98. New York and Oxford: Berghahn Books, 2008.

United States Holocaust Memorial Museum, RG-25.024M, Selected Records of the Romanian Ministry of Work, Health and Central Protection - Central Office of Romanianization (Aryanization) 1939-1944 Reel 4 File 697, Reel 11 File 9, Reel 13 File 12, Reel 13 File 740, Reel 15 File 14, Reel 16 File 14, Reel 17 File 16, Reel 25 File 648.

United States Holocaust Memorial Museum, RG-25.004M Selected Records from the Romanian Information Service 1936-1948, Reel 16 File 22539, Reel 23 File 20521, Reel 83 File 99420.

United States Holocaust Memorial Museum, RG-54.001 Selected Records from the Moldova National Archives: Chişinău, Reel 7 File 6586, Reel 7 File 6590.

United States Holocaust Memorial Museum, RG-25.003M, Selected Records from the Romanian Ministry of Defense 1940-1945 Reel 22 File 6262, Reel 27 File 6627, Reel 127 File 177, Reel 128 File 96, Reel 657 File 32.

United States Holocaust Memorial Museum, RG-25.051, Records of the World Jewish Congress in Romania Burdujeni CME4B, 016983.

United States Holocaust Memorial Museum, RG-31.006M, Czernowitz Oblast Archives Records Reel 15 File 93, Reel 15 File 121, Reel 22 File 38, Reel 22 File 329, Reel 22 


\section{IntroductionReferences}

File 576, Reel 23 File 18, Reel 27 File 76, Reel 34 File 73, Reel 35 File 73, Reel 37 File 4, Reel 37 File 6, Reel 37 File 236.

United States Holocaust Memorial Museum, RG-54.004M, Selected Records of the Liaison Office (Under the Office of the Chairman of the Council of Ministers) for Bessarabia, Bukovina and Transnistria, 1941-1944 Reel 3 File 11, Reel 4 File 14, Reel 5 File 16.

University of Southern California Shoah Foundation Institute, Visual History Archives. Hoffer L. (1995). Interview 945. Tape 2.

Vági, Zoltán, Csősz, Lászlo, and Kádár, Gábor (eds.). The Holocaust in Hungary: Evolution of a Genocide. Lanham, MD: AltaMira Press, 2013.

Yad, Vashem. The Collection of the Righteous among the Nations File M.31.2/10658, File M.31.2/10818, File M.31.2/725, File M.31.2/4779, File M.31.2/10358, File M.31.2/ 7338, File M.31.2/10180, File M.31.2/9669, File M.31.2/10108, File M.31.2/6084, File M.31.2/10023. 